UNIVERSIDADE ESTADUAL DO CENTRO-OESTE PROGRAMA DE PÓS-GRADUAÇÃO EM ADMINISTRAÇÃO

MESTRADO PROFISSIONAL EM ADMINISTRAÇÃO

PATRÍCIA INEZ DA SILVA MACHADO

FATORES CAUSADORES DE ESTRESSE: UM ESTUDO DESCRITIVO COM OS OFICIAIS DE JUSTIÇA AVALIADORES FEDERAIS

DISSERTAÇÃO

GUARAPUAVA

2016 


\section{FATORES CAUSADORES DE ESTRESSE: UM ESTUDO DESCRITIVO COM OS OFICIAIS DE JUSTIÇA AVALIADORES FEDERAIS}

Dissertação apresentada como requisito parcial à obtenção do título de Mestre em Administração, do Programa de Pós-Graduação em Administração, da Universidade Estadual do Centro-Oeste, Área de concentração: Estratégia e Inovação e Tecnologia

Orientador: Professor Dr. Sílvio Roberto Stefano 
Catalogação na Publicação

Biblioteca Central da Unicentro, Campus Santa Cruz

\begin{tabular}{|c|c|}
\hline \multirow[t]{6}{*}{ M149f } & $\begin{array}{l}\text { Machado, Patrícia Inez da Silva } \\
\text { Fatores causadores de estresse: um estudo descritivo com os oficiais } \\
\text { de justiça avaliadores federais / Patrícia Inez da Silva Machado. - - } \\
\text { Guarapuava, } 2016 \text {. } \\
\text { ix, } 76 \mathrm{f} .: \text { il. } ; 28 \mathrm{~cm}\end{array}$ \\
\hline & $\begin{array}{l}\text { Dissertação (mestrado) - Universidade Estadual do Centro-Oeste, } \\
\text { Programa de Pós-Graduação em Administração, Mestrado Profissional em } \\
\text { Administração, área de concentração em Estratégia e Inovação e } \\
\text { Tecnologia, } 2016\end{array}$ \\
\hline & $\begin{array}{l}\text { Orientador: Silvio Roberto Stefano } \\
\text { Banca examinadora: Silvio Roberto Stefano, Erivelton Laat, Sandra } \\
\text { Mara de Andrade, Edgar Gandra }\end{array}$ \\
\hline & Bibliografia \\
\hline & $\begin{array}{l}\text { 1. Administração. 2. Fatores estressores ocupacionais. 3. Oficiais de } \\
\text { Justiça Avaliadores Federais. 4. Estresse. I. Título. II. Programa de Pós- } \\
\text { Graduação em Administração. }\end{array}$ \\
\hline & CDD 658 \\
\hline
\end{tabular}




\title{
FATORES CAUSADORES DE ESTRESSE: UM ESTUDO DESCRITIVO COM OS OFICIAIS DE JUSTIÇA AVALIADORES FEDERAIS
}

Dissertação aprovada em 11/06/2016 como requisito parcial para obtenção do grau de Mestre, no Programa de Pós-Graduação em Administração - Mestrado Profissional em Administração, Área de concentração Estratégia, da Universidade Estadual do Centro Oeste, pela seguinte banca examinadora:

\author{
Orientador: Dr. Silvio Roberto Stefano \\ PPGADM / Unicentro \\ Prof. Dr. Erivelton Laat \\ PPGADM / Unicentro \\ Profa Dra. Sandra Mara de Andrade \\ PPGADM / Unicentro \\ Prof $^{\circ}$. Dr. Edgar Gandra \\ PPGH - UFPEL
}




\section{AGRADECIMENTOS}

À Deus, porque sem ele não sou nada.

Aos meus Pais, por entenderem a minha ausência e por me amarem incondicionalmente.

À Unicentro, por ter me acolhido tão carinhosamente.

Aos Professores do Mestrado, pelos conhecimentos compartilhados, e, em especial, ao Professor Marcos Roberto Kühl, pela generosidade em me ajudar com a análise dos resultados desse estudo.

Aos colegas de curso, por todo companheirismo.

À Assojaf PR e Assojaf MG por terem prontamente me auxiliado na realização da pesquisa de campo e por toda a colaboração dispensada.

Ao Professor Dr. Sílvio Roberto Stefano, pelo apoio e confiança durante todos os momentos de incerteza que ocorreram ao longo do caminho, por ter sido um amigo além de orientador, por ter me ajudado a encontrar o tema de pesquisa, e por ter acreditado que iríamos conseguir concluir este estudo mesmo quando tudo parecia perdido.

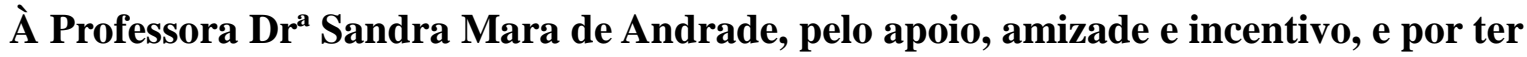
aceitado me orientar na pós-graduação.

Às amigas Elaine e Neirisléia, que mesmo distante, mantiveram seu vínculo de amizade, e nunca mediram esforços para me auxiliar e apoiar.

Às irmãs que a vida me deu, Eleonora e Lorena, por entenderem os meus momentos de ausência e pelas lágrimas e sorrisos compartilhados.

Aos Oficiais de Justiça Avaliadores Federais que doaram um pouquinho do seu tempo para participar dessa pesquisa, sem eles esse estudo não seria possível. 


\section{RESUMO}

Esta dissertação está vinculada à área de concentração Estratégia, Inovação e Tecnologia do PPGADM e à linha de pesquisa Estratégia do Mestrado Profissional em Administração da Universidade Estadual do Centro-Oeste (UNICENTRO). Este estudo teve como foco de pesquisa os Oficiais de Justiça Avaliadores Federais associados à Assojaf MG ou Assojaf PR. O objetivo geral foi identificar os fatores ocupacionais que causam estresse na atividade profissional da referida população. Os dados foram coletados no período de dezembro de 2015 a janeiro de 2016 e utilizou-se como instrumento um questionário composto de questões aderentes ao Modelo Teórico de Explicação do Estresse Ocupacional em Gerentes (MTEG), desenvolvido por Zille (2005), bem como questões constantes no estudo de Merlo et al. (2012). Identificou-se que a maior parte da amostra pesquisada declarou ser do sexo masculino, ter idade entre 31 e 40 anos, atuar como Oficial de Justiça de 11 a 20 anos, possuir pós-graduação completa, não exercer outra atividade profissional, ser casado ou ter uma união estável e estar lotado no interior do Estado. Neste estudo, foram identificados como fatores ocupacionais que causam estresse na atividade profissional o fator sobrecarga de trabalho, o fator reconhecimento profissional, $\mathrm{o}$ fator ameaça/agressão/violência, $\mathrm{o}$ fator autorreconhecimento e o fator clareza de informação. Nesse sentido, identificou-se que o fator sobrecarga de trabalho apresentou a média mais elevada em relação aos demais e pode ser indicado como o principal fator relacionado ao estresse ocupacional na população estudada. Não se verificou diferença, em nenhum dos fatores, em função do gênero. Mas em relação ao local de lotação, verificou-se que a sobrecarga de trabalho e o reconhecimento são fatores nos quais existe diferença entre os grupos a partir da lotação. Desse modo, os resultados indicam a existência de diferença entre os lotados na capital e os lotados no interior, com médias superiores, no caso da sobrecarga de trabalho, para os lotados na capital e com médias superiores, no caso do reconhecimento profissional, para os lotados no interior. Identificou-se, ainda, que $73,9 \%$ da amostra afirmou já ter sofrido ameaça/violência/agressão verbal no exercício da função.

Palavras Chave: Fatores estressores ocupacionais, Oficiais de Justiça Avaliadores Federais, estresse. 


\begin{abstract}
This work is linked to the concentration area Estratégia, Inovação e Tecnologia do PPGADM and to the research line Estratégia do Mestrado Profissional em Administração da Universidade Estadual do Centro-Oeste (UNICENTRO). This study had as research focus the Federal Appraiser Justice Officers associated with Assojaf MG or Assojaf PR. The general goal was to identify occupational factors that cause stress in the professional activity of the referred population. Data were collected from December 2015 to January 2016 and the research instrument used was a survey composed by questions related to the Modelo Teórico de Explicação do Estresse Ocupacional em Gerentes (MTEG) developed by Zille (2005), as well as questions contained in the study by Merlo et al. (2012). It was found that most of the sample surveyed claimed to be male, aged between 31 and 40 years, acting as Justice Officer from 11 to 20 years, postgraduated, not engaged in any other professional activity, married or in an stable relationship and allocated in the countryside of the state. In this study, were identified as occupational factors that cause stress in the professional activity the work overload factor, the professional recognition factor, the threat / aggression / violence factor, self-recognition factor and the clarity of information factor. In this sense, it was identified that the work overload factor showed the highest average in relation to other factors and may be indicated as the main factor related to occupational stress in the studied population. There was no gender-based difference in any of the factors. Regarding the place of allocation, it was found that the work overload and recognition are factors differ between the groups based on allocation. The results indicate the existence of differences between capital allocated and countryside allocated subjects, with higher averages in the case of work overload factor for capital allocated subjects and higher average in the case of professional recognition for countryside allocated subjects. It was also found that $73.9 \%$ of the sample claimed to have suffered threats / violence / verbal abuse on duty.
\end{abstract}

Key Words: occupational stressors factors, Federal Appraiser Justice Officers, stress. 


\section{RESUMEN}

Este trabajo está ligado a la zona de concentración Estrategia, Innovación y Tecnología PPGADM y la línea de investigación Strategy Maestría Profesional en Administración de Empresas por la Universidad Estatal de Medio Oeste (UNICENTRO). Esta investigación se centran estudio de los alguaciles Tasadores Federal asociada con Assojaf MG o Assojaf PR. El objetivo general fue identificar los factores que causan estrés en el trabajo en la actividad profesional de esa población. Los datos fueron recolectados a partir de diciembre 2015-enero 2016 y fue utilizado como instrumento, un cuestionario compuesto por preguntas de los miembros del modelo teórico de Estrés Ocupacional Explicación para los directores (MTEG) desarrollados por Zille (2005), así como las cuestiones contenida en el estudio de Merlo et al. (2012). Se encontró que la mayor parte de la muestra de encuestados afirmó ser varón, de edad entre 31 y 40 años, en calidad de agente judicial de 11 a 20 años, tienen graduado íntegros, sin ninguna otra actividad profesional, estar casado o tener un estable y ser vendidos dentro del estado. En este estudio, que fueron identificados como factores ocupacionales que causan estrés en la carga de trabajo profesional factor de actividad, factor de reconocimiento profesional, el factor de amenaza / agresión / violencia, factor de auto-reconocimiento y la claridad del factor de información. En este sentido, se identificó que el factor de carga de trabajo mostró el promedio más alto en relación con el otro y puede ser indicado como el factor principal relacionada con el estrés en el trabajo en la población estudiada. No hubo diferencias en ninguno de los factores sobre la base del género. En lo que respecta al lugar de almacenamiento, se encontró que la sobrecarga de trabajo y el reconocimiento son factores en los que hay diferencias entre los grupos de la media. Los resultados indican la existencia de diferencias entre concurrido en la capital y el interior lleno de gente con promedios más altos en el caso de sobrecarga de trabajo, de lleno en la capital y por encima de la media en el caso del reconocimiento profesional de lleno en el interior. Se encontró también que el 73,9\% de la muestra afirmó haber sufrido amenazas / violencia / abuso verbal en el trabajo.

Palabras Clave: estresores ocupacionales, agentes judiciales Tasadores Federal, el estrés. 


\section{LISTA DE FIGURAS}

Figura 1 - Síntese da estrutura do trabalho 15

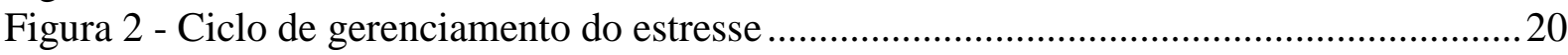

Figura 3 - Fatores que determinam o stress ............................................................... 21 


\section{LISTA DE GRÁFICOS}

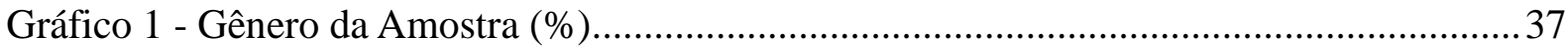

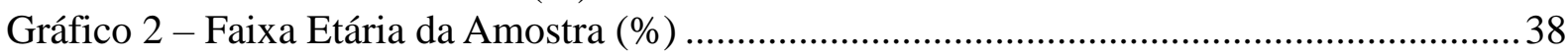

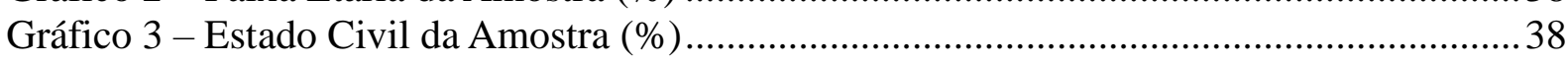

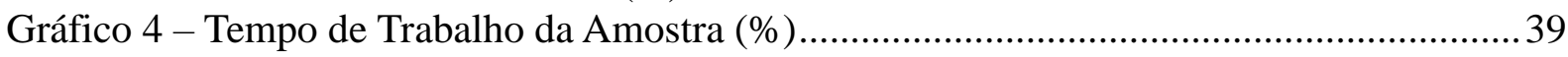

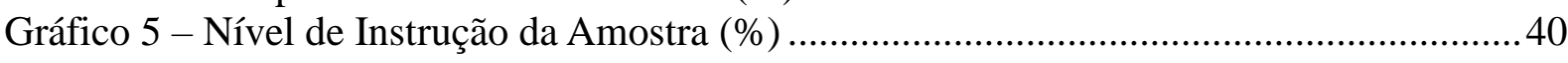

Gráfico 6 - Localidade de Lotação da Amostra (\%) .................................................................. 41 


\section{LISTA DE QUADROS}

Quadro 1 - Conceito de estresse. 16

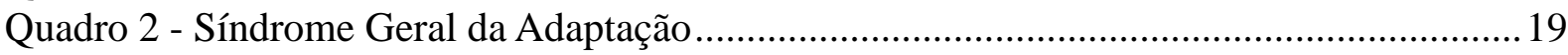

Quadro 3 - Consequências que o stress excessivo pode trazer para as empresas e para os

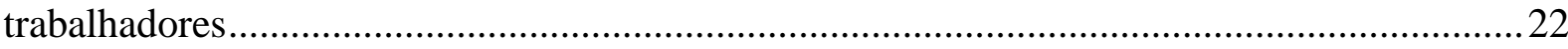

Quadro 4 - Fases do modelo de Lazarus e Folkman..............................................................25

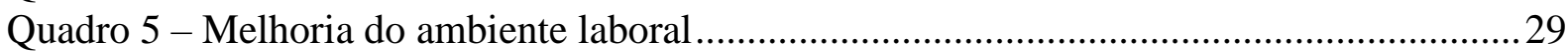

Quadro 6 - Enfoque biopsicossocial do ser humano............................................................. 30

Quadro 7 - Categorias de análise utilizadas no instrumento de coleta de dados. .....................33

Quadro 8- Síntese do método de pesquisa da dissertação.......................................................35 


\section{LISTA DE TABELAS}

Tabela 1 - Ameaça/Agressão/Violência Sofrida pela Amostra no Exercício da Profissão ...... 41

Tabela 2 - Bem Particular Danificado ou Roubado no Exercício da Função .......................... 42

Tabela 3 - Segurança no Exercício da Função .................................................................... 43

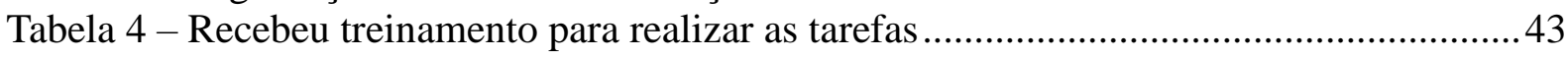

Tabela 5 - Média, Desvio-Padrão e Coeficiente de Variação das variáveis............................. 45

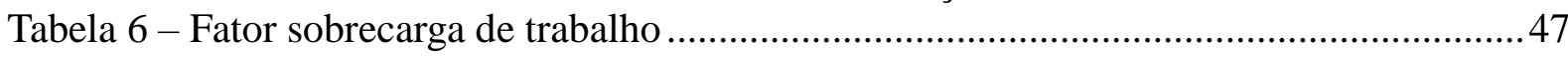

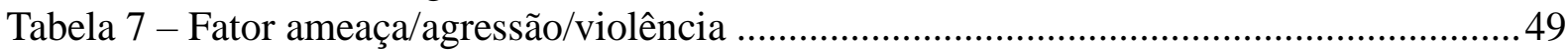

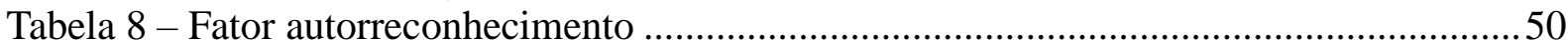

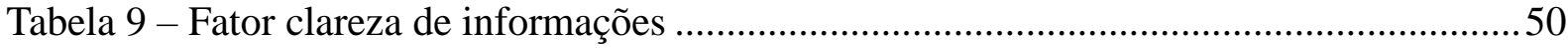

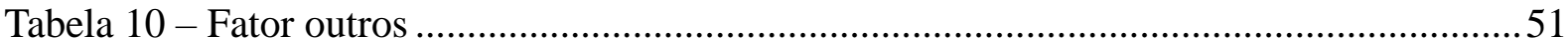

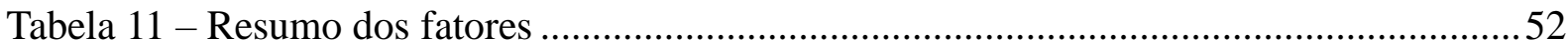

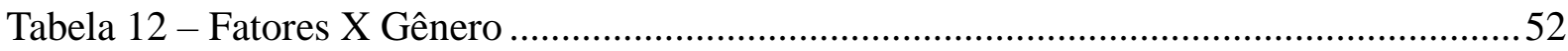

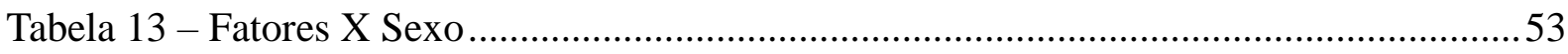

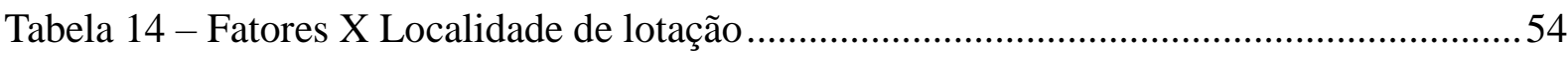




\begin{tabular}{|c|}
\hline SUMÁRIO \\
\hline 1 INTRODUÇÃO . \\
\hline 1.1 CONTEXTO DA ESQUISA.. \\
\hline 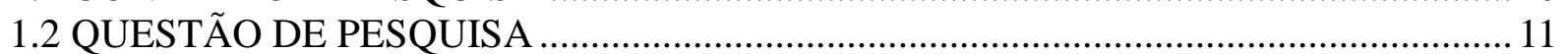 \\
\hline 1.3 OBJETIVOS \\
\hline 1.3.1 Objetivo Geral \\
\hline 1.3.2 Objetivos Específicos ... \\
\hline 1.4 JUSTIFICATIVA \\
\hline 1.5 ESTRUTURA DO TRABALHO \\
\hline
\end{tabular}

2 REFERENCIAL TEÓRICO ……..........................................................................................16

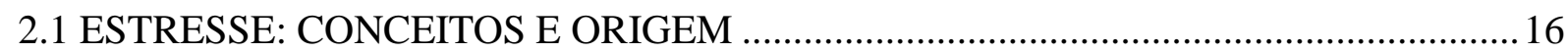

2.2 ESTRESSE: TIPOS E FASES DO ESTRESSE .......................................................... 19

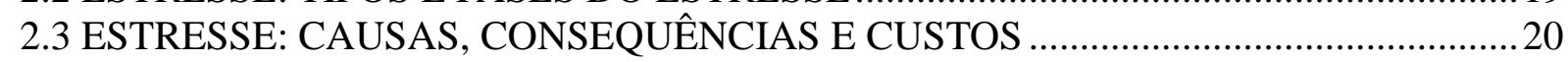

2.4 ESTRESSE OCUPACIONAL E OS FATORES ESTRESSORES …………………......

2.5 OS FATORES ESTRESSORES E AS ATIVIDADES DOS OFICIAIS DE JUSTIÇA AVALIADORES FEDERAIS .................................................................................. 2.6 QUALIDADE DE VIDA NO TRABALHO: GESTÃO PARA A PREVENÇÃO E

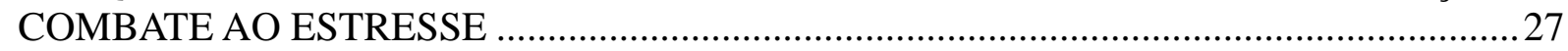

3 MÉTODO DE PESQUISA ….................................................................................................32

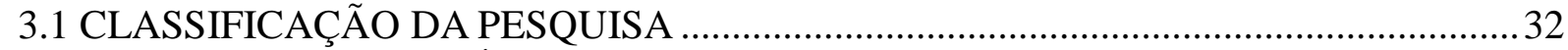

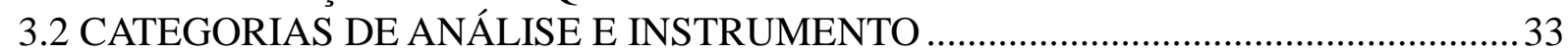

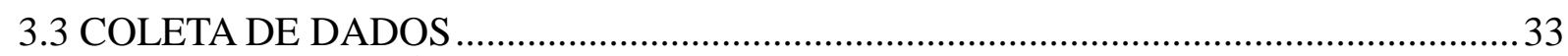

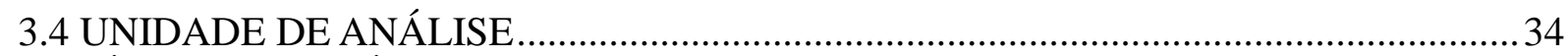

3.5 SÍNTESE DO MÉTODO DE PESQUISA ....................................................................... 35

4 ANÁLISE DOS RESULTADOS DA PESQUISA ……...................................................36

5 CONSIDERAÇÕES FINAIS......................................................................................................55

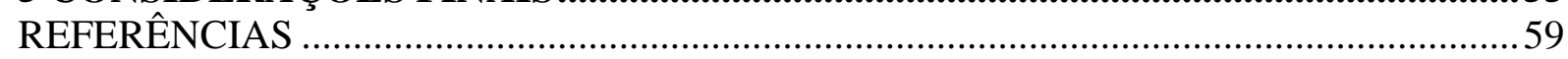

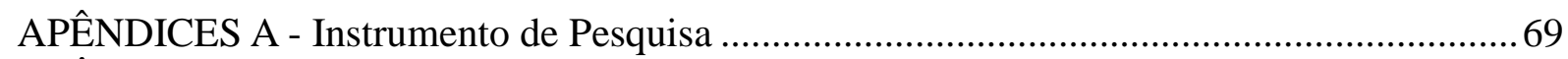

APÊNDICE B - Termo de consentimento de pesquisa …………………………………........ 75 


\section{INTRODUÇÃO}

\subsection{CONTEXTO DA PESQUISA}

As organizações atuais apresentam diferenças em relação às organizações do passado, uma dessas diferenças é a crescente busca por uma melhor qualidade de vida no trabalho (QVT), tema que abrange a tentativa de eliminação/atenuação dos fatores estressores ocupacionais.

Tanto nas organizações privadas quanto as públicas, passou a se entender que a eliminação ou atenuação dos fatores estressores relacionados ao trabalho geram uma melhor qualidade de vida para os trabalhadores e servidores, já sendo possível identificar pesquisas relacionadas à QVT no Setor Público Federal. Como, por exemplo, a realizada pelo Tribunal Regional do Trabalho da $18^{\text {a }}$ Região, divulgada em 2011 (TRT 18, 2011). Nesse sentido, o plano estratégico da Justiça do Trabalho, para o período de 2015 a 2020, possui a valorização das pessoas como um dos valores organizacionais e a promoção da melhoria da gestão de pessoas e da qualidade de vida como um dos seus objetivos estratégicos (CSJT, 2014).

Nessa perspectiva, entende-se que a maioria das organizações que investem em programas de bem-estar têm descoberto os benefícios trazidos por eles (ROBBINS, 2005; BERRY; MIRABITO; BAUN, 2010). Em relação a esses benefícios, de acordo com Alberto Ogata [presidente (2005-2014) da Associação Brasileira de Qualidade de Vida - ABQV] (ANAJUSTRA, 2010, p. 01), “[...] Nos Estados Unidos, a cada dólar investido em Qualidade de Vida, economizam-se cinco dólares em gastos com assistência médica e combate ao absenteísmo e presenteísmo [...]".

O estudo realizado por Arellano (2008) em 27 organizações, cujo um dos objetivos era analisar os resultados das ações dos programas de qualidade de vida, identificou que, dentre as organizações pesquisadas, $72 \%$ apresentou redução no índice de turnover (rotatividade) e $40 \%$ apresentou diminuição no índice de absenteísmo após a implantação dos programas de QVT.

Além disso, percebeu-se que a satisfação do funcionário (público ou privado) impacta diretamente na qualidade de atendimento ao cliente (AMORIM, 2010). Nesse sentido, aponta-se que uma das formas de a alcançar é por meio da observação de aspectos tais como: remuneração adequada, melhoria das condições de trabalho, oportunidade de desenvolvimento pessoal, dentre outros (SADIR; LIPP, 2009).

Desse modo, a QVT passou a ser um dos itens constantes no planejamento 
estratégico organizacional, sendo também tratada como uma vantagem competitiva para atrair e manter bons profissionais (AMORIM, 2010). Tem-se, ainda, que a preocupação com o diagnóstico e a intervenção das condições disfuncionais do trabalho extrapola a busca de uma maior competitividade e qualidade nas relações pessoais e organizacionais, demonstrando responsabilidade social por parte da organização (GOULART JUNIOR et al., 2014). Assim, um dos temas abordados pela QVT é a redução/eliminação do estresse ocupacional.

Nesse sentido, o estresse pode trazer prejuízos para a qualidade de vida dos indivíduos além de propiciar o desenvolvimento de vários tipos de doenças (SADIR; BIGNOTTO; LIPP, 2010; LIMONGI-FRANÇA; RODRIGUES, 2007).

Assim, no campo do estresse organizacional, há um esforço especial no sentido de identificação dos estressores, que são aqueles eventos que provocam respostas indicativas de estresse, interferindo na saúde, bem-estar e desempenho do ser humano (SADIR; LIPP, 2009). Tal identificação se torna relevante a fim de se efetuar as implementações organizacionais necessárias à prevenção e diminuição do estresse entre os profissionais (FINNEY et al., 2013), uma vez que os estressores ocupacionais impactam na qualidade de vida do trabalhador, afetando diretamente a sua saúde e seu bem-estar (GOULART JUNIOR et al., 2014).

Em relação ao direcionamento dos estudos do estresse, eles podem ser direcionados à abordagem bioquímica, psicológica e sociológica, abordagens estas que podem ser consideradas interligadas e complementares (ZILLE; BRAGA; MARQUES, 2014). Nesse sentido, afirma-se que todo o indivíduo "[...] é um complexo biopsicossocial, isto é, tem potencialidades biológicas, psicológicas e sociais que respondem simultaneamente às condições de vida [...] (ALBUQUERQUE; LIMONGI-FRANÇA, 1998, p. 41). Por fím, esclarece-se que o estresse pode ser dividido em dois tipos, o distress (estresse negativo) e o eustress (estresse positivo) (STEFANO; BONANATO; RAIFUR, 2013; LIMONGIFRANÇA; RODRIGUES, 2007), haja vista que tanto as situações consideradas como ruins quanto as situações consideradas como boas podem gerá-lo (STEFANO; BONANATO; RAIFUR, 2013).

\subsection{QUESTÃO DE PESQUISA}

Tanto em organizações privadas quanto públicas, a realização de pesquisas contribui na identificação de pontos deficitários e que podem ser melhorados por elas. 
Em relação à população pesquisada nesta dissertação, segundo a Oficial de Justiça Yvone Barreiros Moreira (Presidente da Associação dos Oficiais de Justiça do Estado de São Paulo - AOJESP), “O Oficial de Justiça é o Juiz na rua. Ele tem de localizar as partes e cumprir a determinação judicial [...], eles têm de ter um lado psicólogo, um lado assistente social, e, às vezes, atuar como policial [...]” (MATSUURA, 2009). Além disso, os Oficiais de Justiça lidam com vários tipos de pessoas no seu dia a dia, tendo sua integridade física colocada em risco na execução do seu trabalho (PIMENTEL, 2014). Desse modo, ameaças e violências, verbais e físicas, permeiam a sua atividade profissional (PIMENTEL, 2014; LIMA, 2014).

Nesse sentido, um estudo que objetivava identificar os efeitos do trabalho sobre a saúde de Oficiais da Justiça Federal de Porto Alegre identificou que um dos fatores de sofrimento apontado por eles foi a ausência de treinamento inicial para a execução da atividade. Segundo os respondentes, 90,1\% não recebeu treinamento inicial e, dos 9,9\% que afirmou ter recebido treinamento, apenas $12,5 \%$ foi treinado por meio de curso ofertado pela administração, os outros $75,0 \%$ daqueles que receberam treinamento foram treinados por outro colega de trabalho e 12,5\% indicaram outra forma (MERLO et al., 2012).

Essa ausência de treinamento se torna ainda mais preocupante quando se considera que a exposição à violência é considerada algo inerente a esse tipo de atividade (SINTRAJUFE RS, 2013). Nesse sentido, 97,10\% dos pesquisados afirmaram que se sentem inseguros no exercício da função. De acordo com eles, o que mais contribui com a insegurança são os lugares perigosos (77,9\%), o trabalho solitário (77,9\%), a violência urbana em geral $(69,1 \%)$ e as situações conflitantes decorrentes do mandado $(53,5 \%)$ (SINTRAJUFE RS, 2013).

Diante desse contexto, e partindo-se do pressuposto de que são vários os fatores que levam ao estresse, e que este pode trazer consequências negativas para o indivíduo, para as organizações e para a sociedade como um todo, a problemática de pesquisa foi: em que medida os Oficiais de Justiça Avaliadores Federais consideram a violência no desempenho da sua atividade e a sobrecarga de trabalho como fatores estressores? Quais tipos de atividades profissionais desempenhadas por eles geram mais estresse? A seguir apresentam-se os objetivos desse estudo. 


\subsection{OBJETIVOS}

\subsubsection{Objetivo Geral}

Identificar os fatores ocupacionais que causam estresse na atividade profissional dos Oficiais de Justiça Avaliadores Federais associados à Assojaf MG ou Assojaf PR.

\subsubsection{Objetivos Específicos}

a) Investigar se há uma diferença estatística significativa em relação aos gêneros e ao local de lotação (capital e interior) dos Oficiais de Justiça Avaliadores Federais no tocante aos fatores geradores de estresse na atividade profissional;

b) Identificar se a amostra pesquisada sofre agressões/violência (verbais e físicas) no exercício da sua atividade profissional;

c) Identificar se há uma sobrecarga de trabalho no exercício da função dos Oficiais de Justiça avaliadores Federais.

\subsection{JUSTIFICATIVA}

Afirma-se que a presença do estresse no ambiente laboral está em ascendência (GOULART JUNIOR et al., 2014). Ele tem sido uma das preocupações dentre os problemas de saúde ocupacional, em razão das sérias consequências que pode provocar (SADIR; BIGNOTTO; LIPP, 2010). Desse modo, se mostra relevante identificar suas causas (GOULART JUNIOR et al., 2014), pois, conforme apontado por Merlo et al. (2012), a implementação de políticas de promoção e prevenção à saúde pertinentes no âmbito laboral requer a identificação, o quanto antes, das fontes agressoras à saúde que possam levar ao adoecimento.

De acordo com a pesquisa realizada por Merlo et al., a qual buscou estudar o trabalho e a saúde dos Oficiais de Justiça Federal de Porto Alegre, dentre os aspectos relacionados à atividade laboral que exerceriam influência negativa sobre a saúde dos Oficiais de Justiça estão a sobrecarga de trabalho causada pelas atribuições legais, a violência urbana, o perigo da relação com o indivíduo a ser intimado pelo oficial, o trabalho em si (quando este traz situações de sofrimento psíquico relacionados ao conteúdo da execução dos mandados) e a questão da informatização da Justiça Federal brasileira, a qual traz consigo o medo do esvaziamento da função dos Oficiais de Justiça, haja vista que haveria uma redução de grande 
parte de suas atribuições (MERLO et al., 2012). Este último aspecto corrobora com a ideia de que a crescente informatização global traz consigo muitas incertezas, dentre elas o aumento da ameaça ao emprego (LIMONGI-FRANÇA; RODRIGUES; 2007).

Tem-se ainda a necessidade de que os estudos realizados sejam capazes de identificar os resultados conforme os setores de trabalho, uma vez que algumas atividades realizadas em diferentes setores podem ser mais desgastantes do que outras (GOULART JUNIOR et al., 2014). Nesse sentido, segundo Fábio de Paula Santos, Diretor Jurídico e de Acompanhamento Político-Legislativo da Associação dos Oficiais de Justiça Avaliadores Federais do Estado de Goiás (ASSOJAF-GO), a situação identificada na pesquisa de Merlo et al. (2012) se assemelha ao cotidiano dos Oficiais de Justiça goianos, o problema, de acordo com ele “[...] é que a maioria dos estudos realizados pelos Tribunais aborda todos os servidores. Não há um levantamento por grupo, como oficiais de Justiça, agentes de segurança e servidores que trabalham internamente, como este estudo realizado no Sul" (ASSOJAF-GO, 2013 b).

Desse modo, percebe-se que vários aspectos relacionados ao exercício da função dos Oficiais de Justiça Avaliadores Federais, tais como a violência/agressão e a sobrecarga de trabalho, podem se mostrar como fatores estressores no desempenho da sua atividade profissional. Nessa perspectiva, este estudo pretende trazer como contribuições à teoria a identificação e análise dos fatores geradores de estresse nestes servidores públicos federais. No tocante às contribuições práticas, destaca-se a importância de que os estudos realizados no âmbito do serviço público federal, e nas organizações como um todo, sejam realizados de modo que os resultados possam ser identificados em função dos cargos que foram abrangidos pela pesquisa, a fim de que se possam conhecer as especificidades relacionadas aos cargos que compõe a organização e o tema pesquisado.

Desse modo, se torna possível propor implementações mais adequadas para a redução ou eliminação dos problemas diagnosticados, envolvendo programas de QVT e da gestão estratégica de pessoas. Assim, este estudo busca compreender melhor os fatores causadores de estresse relacionados à atividade profissional dos Oficiais de Justiças Avaliadores Federais associados à Assojaf MG ou Assojaf PR.

\subsection{ESTRUTURA DO TRABALHO}

O segundo capítulo contém a fundamentação teórica, que aborda os temas relacionados ao estresse, bem como a gestão da Qualidade de Vida no Trabalho. Sua construção se baseia principalmente em estudos constantes nas plataformas SPELL® 
Scientific Periodicals Electronic Library, IBICT Instituto Brasileiro de Informação em Ciência e Tecnologia ${ }_{2}$ EBSCO e Periódicos Capes http://www.periodicos.capes.gov.br/.

O terceiro capítulo apresenta os procedimentos metodológicos por meio dos quais os dados foram coletados ao longo do estudo, e posteriormente tratados. Desse modo, apresenta a abordagem e a estratégia de pesquisa. A saber: estudo descritivo, com método de abordagem dedutivo e enfoque quantitativo.

O quarto capítulo traz a discussão dos resultados obtidos, a análise dos dados coletados e sua comparação com a teoria pesquisada. Por fim, no capítulo cinco são apresentadas as considerações finais do trabalho, sendo apresentadas as contribuições do estudo, suas limitações e sugestões para estudos futuros. A Figura 1 sintetiza a estrutura do trabalho.

\section{Figura 1 - Síntese da estrutura do trabalho}

CAPÍTULO 1

INTRODUÇÃOO

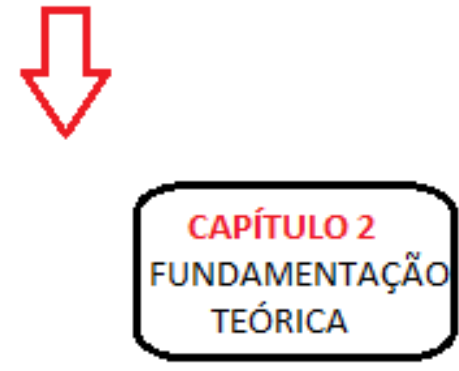

CAPÍTULO 3 MÉTODO DE PESQUISA
CAPÍTULO 4 ANÁLISE DOS RESULTADOS

Fonte: Elaborado pelos autores 


\section{REFERENCIAL TEÓRICO}

Neste capítulo serão abordados os conceitos, origem, modelos, causas, consequências e custos relacionados ao estresse, bem como a importância da gestão da qualidade de vida no trabalho na gestão do combate e controle dos fatores estressores.

\subsection{ESTRESSE: CONCEITOS E ORIGEM}

Dentre os assuntos abordados pela qualidade de vida no trabalho está o estresse. De acordo com Limongi-França $(2009$, p.43) “[...] O stress é uma resposta do corpo à pressão. Ele ocorre quando o organismo responde com o corpo, com a mente e com o coração às condições inadequadas de vida de forma contínua ou muito intensa [...]”. Em outra definição, tem-se que "O estresse pode ser considerado como uma reação do organismo, confrontando situações que, de um modo ou de outro, o deixem desconfortável ou irritada, amedrontada, ou mesmo que deixe uma sensação de extrema felicidade" (STEFANO; BONANATO; RAIFUR, 2013, p. 76).

Então o que significa estar estressado? Limongi-França e Rodrigues (2007, p.174) afirmam que "[...] o stress deve ser entendido como uma relação particular entre uma pessoa, seu ambiente e as circunstâncias às quais está submetida [...]”. No Quadro 1, são expostas outras definições acerca do que é estresse.

\section{Quadro 1 - Conceito de estresse}

\begin{tabular}{|l|l|}
\hline \multicolumn{1}{|c|}{ Autor(es) } & \multicolumn{1}{c|}{ Estresse (conceito/definição) } \\
\hline $\begin{array}{l}\text { Zille (2005, p. } \\
\text { 169) }\end{array}$ & $\begin{array}{l}\text { "sua manifestação está relacionada ao desequilíbrio acentuado entre os níveis de tensão que o } \\
\text { indivíduo recebe do meio (diversos ambientes) e à sua capacidade de psíquica de suportá-los". }\end{array}$ \\
\hline $\begin{array}{l}\text { Limongi-França } \\
\text { e Rodrigues } \\
\text { (2007, p. 30). }\end{array}$ & $\begin{array}{l}\text { "Estado do organismo, após o esforço de adaptação, que pode produzir deformações na } \\
\text { capacidade de resposta atingindo o comportamento mental e afetivo, o estado físico e o } \\
\text { relacionamento com as pessoas". }\end{array}$ \\
\hline $\begin{array}{l}\text { Lipp; Malagris } \\
\text { e Novais (2007, } \\
\text { p. 19) }\end{array}$ & $\begin{array}{l}\text { "é uma reação que temos frente a algo, bom ou mal, que nos obrigue a fazer um esforço, maior } \\
\text { do que usual, para nos adaptarmos ao que está acontecendo, seja no mundo lá fora, seja em } \\
\text { nossa mente". }\end{array}$ \\
\hline $\begin{array}{l}\text { Tamayo (2007, } \\
\text { p. 25) }\end{array}$ & $\begin{array}{l}\text { "mecanismo utilizado pelas pessoas para se adaptarem às exigências do meio externo ou para } \\
\text { responderem a metas que fixam para si próprias". }\end{array}$ \\
\hline $\begin{array}{l}\text { Tavares (2010, } \\
\text { p. 17) }\end{array}$ & $\begin{array}{l}\text { "é o resultado da interação entre o indivíduo e as condições do seu ambiente externo, e o efeito } \\
\text { negativo do estresse surge quando a pessoa atinge o seu limite para a adaptação, ou seja, } \\
\text { quando não encontra mais recursos, surgem doenças”. }\end{array}$ \\
\hline
\end{tabular}

Fonte: Limongi-França e Rodrigues (2007, p. 30); Tavares (2010, p. 17); Lipp; Malagris e Novais (2007, p. 19); Tamayo (2007, p. 25); Zille (2005, p. 169). 
Nota-se que em todas as definições constantes no Quadro 1 a palavra adaptação aparece relacionada ao estresse. Desse modo, pode-se concluir que o estresse estará presente quando existir uma demanda, seja ela interna ou externa, que implique na necessidade de adaptação do organismo.

Em relação a sua origem, o estresse pode ser proveniente de fontes variadas e afetar os indivíduos de formas distintas (ARSHADI; DAMIRI, 2013), podendo provocar consequências físicas, psicológicas e comportamentais (ROBBINS, 2005; SONNENTAG; FRESE, 2003; KALIMO, 1988; KALIMO; MEJMAN, 1988; PAFARO; MARTINO, 2004; PASCHOAL; TAMAYO, 2004; COOPER; DAVIDSON, 1988; LEVINE; SCOTCH, 1970; SANTOS, 2008). No tocante às fontes de estresse, afirma-se que elas estão presentes nos diversos cargos exercidos e que a sua presença pode ser resultante da crescente necessidade de adaptação às mudanças, do ritmo da rotina ao qual as pessoas estão sujeitas, e das relações interpessoais estabelecidas no ambiente organizacional. Sendo que as fontes estressoras mais relatadas no ambiente laboral são o excesso de atividades, a falta de planejamento e os conflitos de interesses e valores (SADIR; LIPP, 2009).

A palavra stress tem a sua origem no latim, e era utilizada, no final do século XVIII, para expressar força, pressão ou esforço (LIMONGI-FRANÇA, 2010). Desse modo, inicialmente o conceito de estresse foi empregado nas ciências exatas, como a engenharia e a física, no sentido do grau de deformação sofrido por um determinado material quando submetido a um esforço de adaptação (LIMONGI-FRANÇA, 2008; LIMONGI-FRANÇA; RODRIGUES, 2007).

Em 1914, Cannon chamou a reação de estresse de síndrome de luta ou fuga (NAKAYAMA, 1997), mas a primeira pessoa a definir o estresse foi o austríaco-canadense Hans Selye, na década de 1930. (LIMONGI-FRANÇA, 2010). Quando ainda era estudante de medicina, Selye observou que alguns sintomas, como falta de apetite, pressão alta, desânimo e fadiga, eram apresentados por pacientes com diferentes tipos de enfermidade (TAVARES, 2010). De acordo com Hans Selye, quando há estímulos (originados de naturezas diversas) que ameaçam a homeostase de um organismo, este tende a produzir um conjunto de respostas específicas que constituem uma síndrome, a qual ele chamou de stress (LIMONGI-FRANÇA; RODRIGUES, 2007). Ele conceituou o estresse como qualquer tipo de adaptação necessária ao indivíduo (LIMONGI-FRANÇA, 2010).

Nessa perspectiva, o estresse não deve ser enxergado como algo necessariamente ruim ou negativo (TAMAYO, 2007; LIMONGI-FRANÇA; RODRIGUES, 2007; GOULART JUNIOR et al., 2014; GMELCH, 1991; NAKAYAMA, 1997), pois, a partir do conceito 
desenvolvido por Selye, o estresse pode ser entendido como algo neutro, que pode se tornar positivo ou negativo (LIMONGI-FRANÇA, 2010).

Desse modo, as situações capazes de desencadear o estresse são denominadas estímulos estressores, ou estressores (provenientes tanto do meio externo quanto do meio interno), e a resposta do organismo a esses estímulos é chamada de estresse (LIMONGIFRANÇA; RODRIGUES, 2007).

Nesse sentido, "O stress resulta de uma interação entre a pessoa e o mundo em que ela vive, pois, o modo como ela percebe e interpreta o seu ambiente é, muitas vezes, o fator preponderante para determinar que reação ela terá [...]" (LIPP; MALAGRIS; NOVAIS, 2007, p. 19). Desse modo, nota-se que os indivíduos não reagem da mesma maneira diante de um determinado estressor (COOPER; DAVIDSON, 1988; NAKAYAMA, 1997; LIPP; MALAGRIS; NOVAIS, 2007).

Tem-se ainda que o estresse pode estar presente em quaisquer lugares e classes sociais, assim, o que irá varia é o estressor, ou seja, o evento gerador de estresse no campo é diferente do da cidade (LIPP; MALAGRIS; NOVAIS, 2007). Nessa perspectiva, assim como, frequentemente, a incidência de determinadas doenças não ocorre de maneira uniforme na população, ou seja, identificam-se variações conforme o país, a região, a idade, o gênero, a classe social, dentre outros parâmetros demográficos (LEVINE; SCOTCH, 1970), estudos indicam que o estresse também apresenta variações conforme o gênero (STEFANO; BONANATO; RAIFUR, 2013; LIPP; MALAGRIS; NOVAIS, 2007; AREIAS; GUIMARÃES, 2004; WOTTRICH et al., 2011), a inserção da pessoa no ambiente rural ou urbano (LEVINE; SCOTCH, 1970) e a posição do indivíduo na estrutura social (FARO; PEREIRA, 2011).

Dessa maneira, assim como as áreas urbanas apresentam uma prevalência maior de algumas doenças do que as áreas rurais, como a hipertensão, por exemplo, entende-se que a prevalência do estresse também apresenta variações quando se pesquisa indivíduos presentes em áreas rurais e urbanas (LEVINE; SCOTCH, 1970). Em relação ao gênero, afirma-se que há um maior número de mulheres com estresse do que homens, e isso, provavelmente, deve estar relacionado às expectativas da sociedade em torno dos vários papéis desempenhados pelo gênero feminino - mãe, esposa, profissional competente, dentre outros (LIPP; MALAGRIS; NOVAIS, 2007). 


\subsection{ESTRESSE: TIPOS E FASES DO ESTRESSE}

Quando a resposta do organismo ao estressor provoca um processo adaptativo inadequado tem-se o distress, ou estresse negativo, e quando essa resposta resulta em um processo adaptativo adequado, fazendo com que o indivíduo responda bem à demanda, tem-se o eustress, que é o estresse considerado positivo (LIMONGI-FRANÇA; RODRIGUES, 2007).

Os modelos teóricos sobre estresse podem ser classificados, segundo o seu foco, em três grandes grupos: nos agentes estressores; na estrutura do sujeito ou nas respostas de enfrentamento; na interação entre sujeito e ambiente (TAVARES, 2010). Neste estudo, o foco de pesquisa são os agentes estressores.

Uma das mais importantes contribuições de Hans Selye nos estudos sobre o estresse foi a Síndrome Geral da Adaptação, caracterizada pelas fases de alarme, resistência e exaustão (LIMONGI-FRANÇA, 2008), conforme disposto no Quadro 2.

\section{Quadro 2 - Síndrome Geral da Adaptação}

\begin{tabular}{|l|l|l|}
\hline \multicolumn{2}{|c|}{ Síndrome Geral da Adaptação } \\
\hline $1^{\text {a }}$ Fase & Alarme & $\begin{array}{l}\text { Os mecanismos são mobilizados para a manutenção da vida, buscando evitar que a } \\
\text { reação não se dissemine. É uma posição de alerta geral do organismo. }\end{array}$ \\
\hline $2^{\text {a }}$ Fase & Resistência & $\begin{array}{l}\text { A adaptação é obtida por meio do desenvolvimento adequado dos canais específicos de } \\
\text { defesa, podendo produzir sub-rotinas somáticos inespecíficos. }\end{array}$ \\
\hline $3^{\text {a Fase }}$ & Exaustão & $\begin{array}{l}\text { Caracterizada por reações de sobrecarga dos canais fisiológicos, falhas dos mecanismos } \\
\text { adaptativos, presença de estímulos permanentes e excessivos, levando o organismo à } \\
\text { morte. }\end{array}$ \\
\hline
\end{tabular}

Fonte: Adaptado de Limongi-França (2008, p. 20).

Desse modo, o Quadro 2 evidencia as fases do estresse descritas por Hans Selye. Já na Figura 2, tem-se o ciclo do gerenciamento do estresse apontado por Gmelch (1991). 
Figura 2 - Ciclo de gerenciamento do estresse

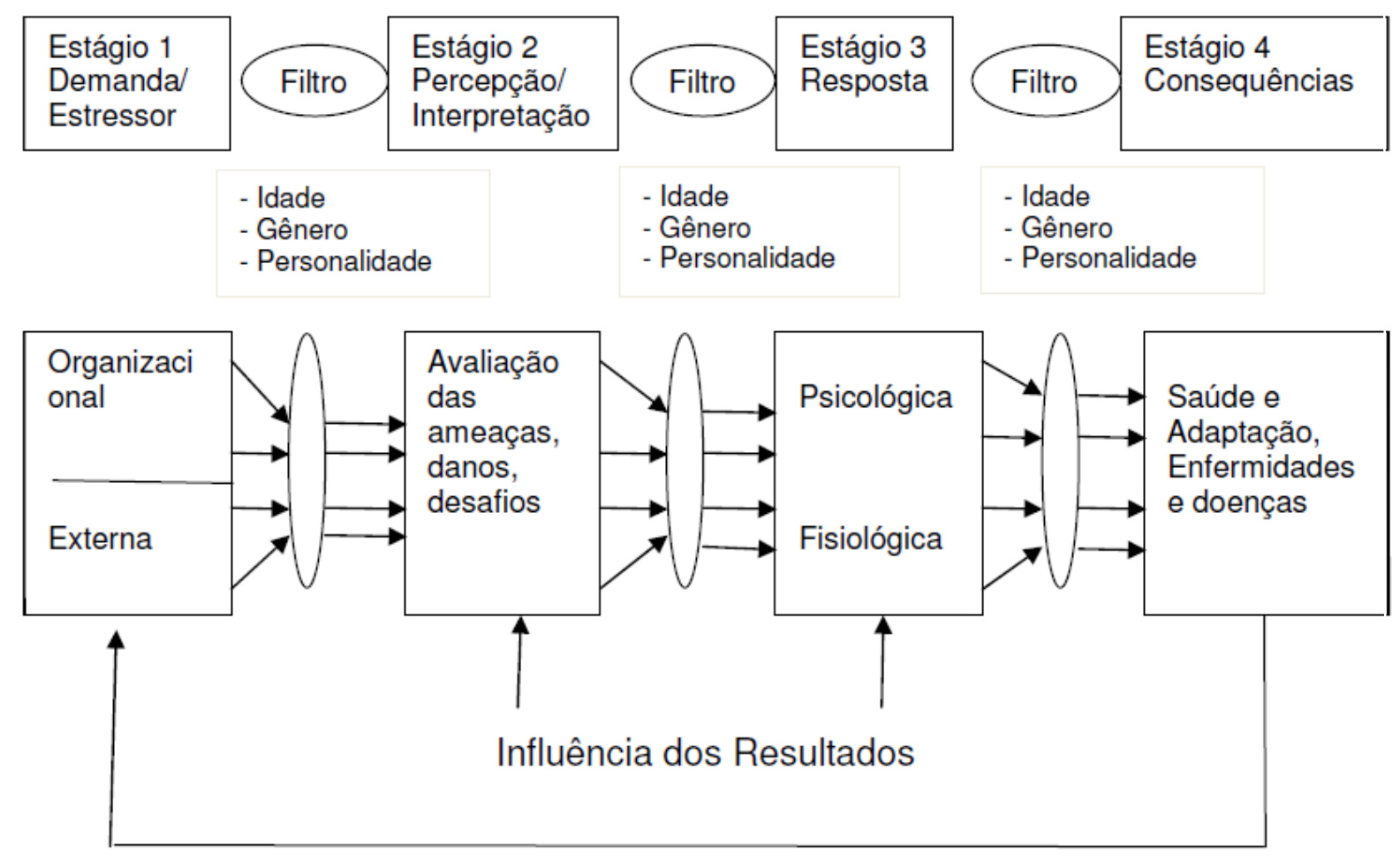

Fonte: Gmelch (1991, p. 33-34)

A Figura 2 ilustra que no ciclo de gerenciamento do estresse há a interferência de alguns filtros, tais como idade, gênero e personalidade.

Assim, diante do exposto nesta seção secundária, percebe-se que "O estresse, seja ele sadio ou negativo, tem sempre uma fonte que é responsável pelo seu aparecimento e desenvolvimento" (TAMAYO, 2007, p.25). Desse modo, faz-se necessário compreender as causas do estresse, suas consequências e custos, tema que será abordado na próxima seção secundária.

\subsection{ESTRESSE: CAUSAS, CONSEQUÊNCIAS E CUSTOS}

O estresse pode estar relacionado a fatores de natureza individual e organizacional (SILVA, 2009), conforme ilustrado na Figura 2. Nesse sentido, "[...] Chamamos de estressor todo evento ou condição capaz de gerar um estado de tensão [...]" (LIPP; MALAGRIS; NOVAIS, 2007, p. 33). Esses estressores podem ser internos e/ou externos (GOULART JUNIOR et al., 2014; LIPP; MALAGRIS; NOVAIS, 2007). 
Figura 3 - Fatores que determinam o stress

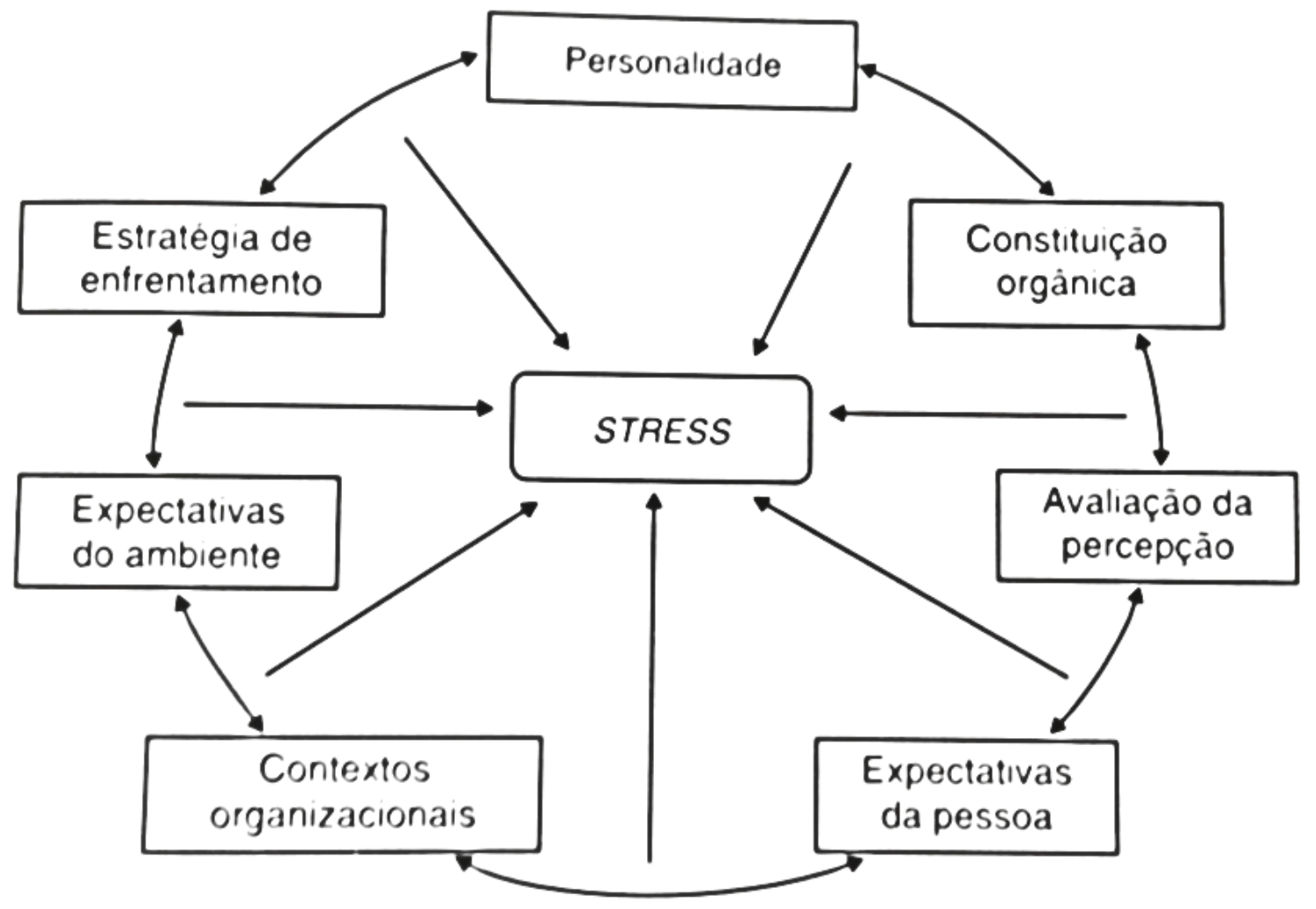

Fonte: Limongi-França e Rodrigues (2007, p. 49).

Na Figura 3 é possível observar-se que diversos fatores determinam o estresse, inclusive o contexto organizacional. Desse modo, o excesso de trabalho, o conflito de funções, as incertezas acerca do futuro profissional, as relações no ambiente de trabalho, o perigo físico, dentre outros, podem ser fatores estressores no ambiente laboral (COOPER; DAVIDSON, 1988).

Apesar de as reações fisiológicas do eustresse e do distresse serem similares (tendência de mãos e pés ficarem suados e frios, do aumento do ritmo cardíaco e da pressão arterial, da elevação da tensão muscular, etc.), no nível emocional as reações ao estresse são bastante distintas. Enquanto o eustresse provoca a motivação e o estímulo no indivíduo para que ele consiga lidar com a situação, o distresse provoca a covardia na pessoa, fazendo com que ela se intimide e tenda a fugir da situação (LIMONGI-FRANÇA, 2010).

Desse modo, os fatores estressores podem afetar o comportamento do indivíduo, trazendo uma diminuição do rendimento e o consumo excessivo de álcool, além de poderem desencadear enfermidades físicas, como a hipertensão, e mentais, como a depressão (COOPER; DAVIDSON, 1988). "[...] O stress pode se tornar excessivo porque o evento estressor é forte demais ou porque se prolonga por tempo muito longo" (LIPP; MALAGRIS; 
NOVAIS, 2007, p. 28)

Em relação ao estresse ocupacional, entende-se que ele produz uma série de consequências indesejáveis tanto no nível individual quanto no nível organizacional (BAHRI YUSOFF, 2013), gerando custos humanos e monetários (PARKER; DE COTIIS, 1983). Desse modo, na Austrália, as consequências provenientes do estresse no ambiente de trabalho são uma preocupação cada vez mais importante para os empregados, para os empregadores e para a sociedade como um todo, em razão do seu impacto sobre os trabalhadores e dos custos trazidos por ele (SWA, 2013). Nesse sentido, Lipp, Malagris e Novais (2007) elencam uma série de consequências que o excesso de estresse pode acarretar para as organizações e indivíduos, conforme disposto no Quadro 3.

\section{Quadro 3 - Consequências que o stress excessivo pode trazer para as empresas e para os} trabalhadores

\begin{tabular}{|c|c|}
\hline Para as empresas prejuízo geral devido a: & $\begin{array}{l}\text { Possíveis consequências do stress excessivo para o } \\
\text { trabalhador: }\end{array}$ \\
\hline 01- Excesso de atrasos & 01- Depressão \\
\hline 02- Excesso de faltas & 02- Falta de ânimo \\
\hline 03-Aumento de licenças médicas & 03- Falta de envolvimento com o trabalho e a organização \\
\hline 04- Alta rotatividade & 04- Faltas e atrasos frequentes \\
\hline 05-Acidentes de trabalho & 05- Excesso de idas ao ambulatório médico \\
\hline $\begin{array}{l}\text { 06- Problemas de relacionamento com a chefia e } \\
\text { subordinados }\end{array}$ & 06- Alcoolismo, tabagismo \\
\hline $\begin{array}{l}\text { 07- Queda na produtividade (qualidade e } \\
\text { quantidade) }\end{array}$ & 07- Saúde física e mental sofre consideravelmente \\
\hline 08- Falta de originalidade nas ideias & $\begin{array}{l}\text { 08- Qualidade de vida e a sensação de bem-estar e de } \\
\text { plenitude também é afetada }\end{array}$ \\
\hline 09- Desempenho irregular & $\begin{array}{l}\text { 09- Dificuldades interpessoais, no âmbito empresarial e fora } \\
\text { dele }\end{array}$ \\
\hline \multirow[t]{6}{*}{ 10- Dificuldades interpessoais com os colegas } & 10- Relações afetivas conturbadas \\
\hline & 11- Divórcios \\
\hline & 12- Farmacodependência \\
\hline & 13- Violência doméstica \\
\hline & 14- Ansiedade \\
\hline & 15- Suicídio \\
\hline
\end{tabular}

Fonte: Adaptado de Lipp, Malagris e Novais (2007, p. 64).

Assim, no Quadro 3, observa-se que, no ambiente laboral, “[...] as consequências do stress podem incluir depressão, falta de ânimo, falta de envolvimento com o trabalho e a organização, faltas e atrasos frequentes, excesso de visitas ao ambulatório médico e farmacodependência" (SADIR; BIGNOTTO; LIPP, 2010, p. 73). Outras consequências do 
estresse são mudanças na produtividade, absenteísmo, rotatividade, mudanças nos hábitos alimentares, aumento do consumo de álcool ou tabaco, inquietação, distúrbios do sono e aceleração da fala (Robbins, 2005). Nessa perspectiva, estudos confirmam que o estresse no trabalho pode diminuir a produtividade e a eficácia no ambiente laboral, além de elevar o absenteísmo (FINNEY et al., 2013) e a rotatividade (ARSHADI; DAMIRI, 2013; FINNEY et al., 2013; MOSADEGHRAD, 2013).

Nesse sentido, acredita-se que "No Brasil, $30 \%$ da população economicamente ativa sofre com o estresse no ambiente de trabalho [...]" (MARTINIANO, 2012, p. 41).

Em relação aos custos ocasionados pelo estresse, na Austrália, um estudo publicado em 2008 relatava que o estresse no trabalho custava $\$ 14,81$ bilhões de dólares australianos por ano para a economia australiana. Os custos diretos dos empregadores australianos causados pelo presenteísmo ( $\$ 6,63$ bilhões de dólares australianos) e pelo absenteísmo ( $\$ 3,48$ bilhões de dólares australianos) eram de \$10,1 bilhões de dólares australianos por ano, e que cada trabalhador perdia 3,2 dias de trabalho por ano em razão de estresse no local de trabalho, resultando em uma perda de produtividade no trabalho de 1,36\% (MEDIBANK PRIVATE, 2008). Tem-se ainda que “[...] em 2001, o absenteísmo por doença custou para a Alemanha, 44,76 bilhões de euros enquanto que para o Reino Unido, a perda foi de 11 bilhões de libras esterlinas [...]" (FAVA, 2007, p.01).

\subsection{ESTRESSE OCUPACIONAL E OS FATORES ESTRESSORES}

Enquanto os estudos de estresse em geral enfocam os estressores gerais presentes na vida das pessoas, os estudos de estresse ocupacional enfocam os estressores relacionados ao ambiente de trabalho, o que diferencia estes dois tipos de estudos (PASCHOAL; TAMAYO, 2004).

No trabalho, o estresse é vivenciado "[...] a partir da capacidade de adaptação, que envolve sempre o equilíbrio obtido entre exigência e capacidade. Se o equilíbrio for atingido, obtém-se o bem-estar; se for negativo, gerará diferentes graus de incerteza, conflitos e sensação de desamparo" (LIMONGI-FRANÇA, 1996, p.149). Nesse sentido, entende-se que “A ocupação profissional, pelas próprias demandas que envolve, pode ser uma fonte de stress significativa [...]” (LIPP; MALAGRIS; NOVAIS, 2007, p. 62).

No tocante a sua conceituação, o estresse ocupacional pode ser definido "[...] como um processo em que o indivíduo percebe demandas do trabalho como estressores, os quais, ao exceder sua habilidade de enfrentamento, provocam no sujeito reações negativas" 
(PASCHOAL; TAMAYO, 2004, p. 46).

Nessa perspectiva, se tem observado que "as rotinas diárias do ambiente laboral, a estrutura e o funcionamento das empresas moldam e definem a saúde organizacional, e, se não forem bem administradas, podem gerar desgaste entre os indivíduos, causando transtornos e stress ocupacional [...]” (VISENTINI et al., 2010).

Desse modo, quando o trabalhador é submetido a um esforço físico constante, a uma sobrecarga de trabalho e tensões no ambiente laboral, as pesquisas relacionadas ao estresse ocupacional se tornam muito significativas, auxiliando na melhoria da qualidade de vida no trabalho e aumentando a produtividade, a competitividade organizacional e a satisfação no trabalho (VISENTINI et al., 2010).

Em relação aos estudos sobre estresse ocupacional, eles podem se basear nos estressores organizacionais, nas respostas dos indivíduos a esses estressores ou nas muitas variáveis integrantes do processo estressor-resposta (PASCHOAL; TAMAYO, 2004; CANOVA; PORTO, 2010), havendo uma tendência em se considerar o estresse ocupacional como um processo estressor-resposta por ser um enfoque mais completo, que abrange tanto o enfoque baseado nos estressores quanto o enfoque baseado nas respostas (PASCHOAL; TAMAYO, 2004).

Os estressores organizacionais podem ser de natureza física, como barulho, ventilação e iluminação do local de trabalho, ou de natureza psicossocial, fatores intrínsecos ao trabalho, conflito/ambiguidade de papéis, autonomia/controle no trabalho, aspectos do relacionamento interpessoal no trabalho e fatores relacionados ao desenvolvimento na carreira. As respostas do indivíduo a esses estressores podem ser positivas ou negativas e podem ser divididas em respostas psicológicas, fisiológicas e comportamentais (PASCHOAL; TAMAYO, 2004).

A teoria de Lazarus e Folkman focaliza a dimensão psicológica do estresse (ZANELATO, 2008). O modelo dos referidos autores “[...] entende que os eventos não são estressantes em si, mas podem vir a se tornar ou não, conforme a forma como são interpretados e a reação que despertam no indivíduo [...]” (SAMPAIO, 2010, p. 34-35). Desse modo, o indivíduo, diante de um agente estressor, realiza uma avaliação a fim de verificar se ele é controlável. No caso afirmativo, a pessoa bloqueará a reação do estresse e voltará a homeostase. No caso negativo, se inicia uma fase de adaptação mais intensa, bem como o surgimento de doenças ou comportamentos de fuga e esquiva (ZANELATO, 2008). Desse modo, esse modelo “[...] enfatiza a função cognitiva do indivíduo na percepção e interpretação das situações de estresse [...]" (SAMPAIO, 2010, p. 34). 
Assim, no modelo de Lazarus e Folkman, o processo de estresse passaria por quatro fases: avaliação primária, avaliação secundária, reavaliação e coping, conforme disposto no Quadro 4.

\section{Quadro 4 - Fases do modelo de Lazarus e Folkman}

\begin{tabular}{|l|l|}
\hline \multicolumn{2}{|c|}{ Fases do modelo de Lazarus e Folkman } \\
\hline $\begin{array}{l}\text { Avaliação } \\
\text { Primária }\end{array}$ & $\begin{array}{l}\text { O indivíduo examina, baseado em seu bem-estar, se a situação ocorrida é irrelevante, positiva ou } \\
\text { estressante. }\end{array}$ \\
\hline $\begin{array}{l}\text { Avaliação } \\
\text { Secundária }\end{array}$ & $\begin{array}{l}\text { Há um julgamento envolvendo as atitudes que podem ser tomadas, ou seja, as estratégias de } \\
\text { enfrentamento ou coping. }\end{array}$ \\
\hline $\begin{array}{l}\text { Reavaliação } \\
\text { É realizada uma nova avaliação baseada nas novas informações obtidas do ambiente e levantadas } \\
\text { pelo próprio indivíduo. }\end{array}$ \\
\hline $\begin{array}{l}\text { Coping ou } \\
\text { enfrentamento }\end{array}$ & $\begin{array}{l}\text { A pessoa adota esforços cognitivos e comportamentais para administrar as demandas quando } \\
\text { estas são consideradas excedentes aos recursos que o indivíduo dispõe. }\end{array}$ \\
\hline
\end{tabular}

Fonte: Adaptado de Sampaio (2010, p. 35).

Essas fases elencadas no quadro acima mediariam a relação pessoa-ambiente, e seriam examinadas por meio de perguntas dirigidas aos indivíduos pesquisados (SAMPAIO, 2010).

\subsection{OS FATORES ESTRESSORES E AS ATIVIDADES DOS OFICIAIS DE JUSTIÇA AVALIADORES FEDERAIS}

A violência vivenciada pelos oficiais de justiça avaliadores federais no desempenho da sua atividade profissional tem trazido à tona questões como a concessão de porte de arma para a categoria, a aposentadoria especial para a classe (ASSOJAF-GO, 2013), o uso de colete à prova de balas e o acesso a equipamentos de proteção no exercício da função (TST, 2014). Ressalta-se ainda que "Apesar de a atividade estar prevista como atividade de risco, não há um adicional de risco para o seu exercício” (MERLO et al., 2012, p. 109).

Além da violência que cerca a profissão, o gap entre o número de Oficiais de Justiça necessários e o número existente (ativos) em cada jurisdição acarreta uma sobrecarga de trabalho para estes profissionais. De acordo com a Oficial de Justiça Yvone Barreiros Moreira, Presidente da Associação dos Oficiais de Justiça do Estado de São Paulo - AOJESP, em 2009, "Nove mil oficiais seriam necessários para dar conta de toda a demanda do Judiciário paulista. Mas temos um déficit de 4.024 oficiais. [...]" (MATSUURA, 2009, p. 01), representando um gap de mais de 44\%. Nesse sentido, conforme aponta Merlo et al. (2012) o aumento da carga 
de trabalho pode se revelar um fator importante no sofrimento no trabalho, pois a redução do número de trabalhadores pode se mostrar nociva à saúde no trabalho.

Nesse sentido, a Associação dos Oficiais de Justiça Avaliadores Federais de Goiás (ASSOJAF-GO, 2015) divulgou um relatório cujo conteúdo contempla os crimes cometidos contra esses servidores públicos. Dentre os tipos de violência sofridos por esses profissionais, no exercício da sua função, pode-se citar: assassinato a tiros no cumprimento de mandado de busca e apreensão; mão e pulso torcidos na entrega de mandados (TRIBUNA JUDICIÁRIA, 2009), dentre outros tipos de agressão. Também se observa que os Oficiais de Justiça pertencentes ao quadro da Justiça do Trabalho não estão imunes aos episódios de violência, a exemplo do Oficial de Justiça Avaliador Federal, de 25 anos de idade, do Tribunal Regional do Trabalho da $1^{a}$ Região que foi morto a tiros ao entregar uma intimação em 2014 (TST, 2014).

Nessa perspectiva, um estudo realizado com os Oficiais de Justiça da Justiça Federal, lotados na Central de Mandados de Porto alegre, que buscava investigar as consequências provocadas pelo trabalho na saúde destes profissionais, apontou que, dentre os pesquisados, no exercício da sua função, $63,8 \%$ tiveram bens danificados, $38,8 \%$ tiveram bens roubados, $65,7 \%$ sofreram algum tipo de acidente ou agressão, 81,7\% sentiram-se ameaçados e 18,8\% foram efetivamente agredidos. Ressalta-se ainda que, de acordo com a pesquisa, não há nenhum tipo de treinamento específico para esses Oficiais de Justiça nem são tomadas quaisquer medidas no sentido de limitar os riscos de exposição à violência. Dentre os participantes do referido estudo, 36,1\% utilizavam antidepressivos, 19,1\% medicamentos para dormir e o mesmo percentual necessitava de ansiolíticos (MERLO et al., 2012).

Outras dificuldades encontradas por esses profissionais são os endereços imprecisos, as situações imprevistas (aquelas que fogem das situações comuns no exercício da função), a falta de interação entre os magistrados e os oficiais de justiça, além dos mandados sem total clareza ou distribuídos de forma incompleta (PIMENTEL, 2014). Para os Oficiais de Justiça da Justiça Federal lotados na Central de Mandados de Porto alegre, as situações mais penosas são: desocupações, despejos, etc. (57,7\%); diligências em locais pouco urbanizados, com histórico de violência, e poucas condições de higiene $(52,1 \%)$; cumprimento de mandados sem as informações necessárias (43,6\%); avaliações socioeconômicas $(28,1 \%)$; mandados em presídios $(28,1 \%)$ e mandados de penhora (25,3\%) (SINTRAJUFE RS, 2013). 
2.6 QUALIDADE DE VIDA NO TRABALHO: GESTÃO PARA A PREVENÇÃO E COMBATE AO ESTRESSE

A percepção de que os resultados organizacionais são influenciados por aspectos relativos à saúde física e mental do trabalhador no ambiente laboral (AMORIM, 2010; MICHIE, 2002), trouxe a implementação de programas de qualidade de vida no trabalho (QVT) nas organizações, buscando-se aumentar o bem-estar dos funcionários e, consequentemente, melhorar o nível de atendimento ao usuário/cliente (AMORIM, 2010; LIMA, 2004);

No tocante ao bem-estar dos funcionários, em entrevista concedida à Associação Nacional dos Servidores da Justiça do Trabalho (ANAJUSTRA, 2010), Alberto Ogata [presidente (2005-2014) da Associação Brasileira de Qualidade de Vida - ABQV] (ANAJUSTRA, 2010, p. 01), afirmou que o equilíbrio entre o bem-estar físico, emocional e pessoal gera uma melhora profissional. Dessa maneira, as organizações estão investindo em programas de QVT buscando propiciar um ambiente laboral saudável (aumentando a disposição do trabalhador), reduzir o absenteísmo (faltas ao trabalho) e o presenteísmo (quando o empregado está presente no trabalho sem condições de exercer as suas atividades), e também aumentar a produtividade (ANAJUSTRA, 2010).

Entende-se que, a partir da década de 1980, a busca pelo aumento da qualidade de vida do trabalhador foi motivada pela procura de elevação das taxas de produtividade, lucro e resolução dos conflitos organizacionais (LIMA; STEFANO; ZAMPIER, 2011). Desse modo, as organizações estão cada vez mais preocupadas com o ambiente organizacional em razão de que a melhora no ambiente organizacional propicia um aumento do desempenho do trabalhador e, consequentemente, uma elevação na produtividade organizacional (PAZINI; STEFANO, 2009). Tem-se ainda que, "Em consequência do ritmo atual mais intenso de trabalho, a preocupação com a qualidade de vida passou a ser uma necessidade para o profissional [...]" (LIMONGI-FRANÇA, 2009, p. 43).

Entretanto, diante da dificuldade de se mensurar os ganhos que a organização obtém com os programas de gestão de pessoas, muitos administradores não dão a devida atenção à tarefa de avaliar os resultados do que foi investido nessas ações. Desse modo, muitas vezes os resultados decorrentes dos programas de qualidade de vida no trabalho (QVT) e de outras atividades organizacionais ligadas à área de gestão de pessoas (como os programas de treinamento e desenvolvimento) não são diretamente relacionados com a obtenção de valores financeiros, como são outras atividades empresariais, como a promoção de vendas 
(OLIVEIRA; LIMONGI-FRANÇA, 2005).

Por outro lado, antes do ano 2000 já se afirmava que “[...] o grande capital da empresa é representado por pessoas capazes, aptas, sadias, equilibradas, criativas, íntegras e motivadas" (MIYAMOTO et al.,1999, p. 90). Nessa perspectiva, Cooper (1988) propõe uma série de perguntas que as organizações deveriam se fazer a fim de se tornarem mais conscientes acerca do valor dos seus recursos humanos. O referido autor afirma que as organizações deveriam começar a formular essas questões a fim de tomarem decisões racionais acerca dos processos de seleção, treinamento, desenvolvimento e alocação de pessoas dentro das empresas. Algumas das perguntas sugeridas por Cooper (1988) são: Qual é o valor total dos ativos humanos da sua organização? Esse valor está aumentando, permanece constante, ou está diminuindo? Quanto capital humano se perdeu em razão de doenças ou de morte prematura? Quanto custou substituir essas pessoas? Quantos profissionais jovens foram perdidos por causa da política de ascensão e mobilidade, ou em razão de uma das duas? Qual foi o custo da perda dessas pessoas em termos de potencial?

A adoção desse tipo de perspectiva, a longo prazo, seria capaz de gerar lucros para a organização que poderiam ser tão vantajosos quanto aqueles auferidos por um novo tipo de avanço tecnológico (COOPER, 1988).

Exemplificando, nas empresas J\&Js para cada dólar que foi investido em programas de bem-estar o retorno foi de US\$ 2, 71 (BERRY; MIRABITO; BAUN, 2010), confirmando a ideia de que "Pessoas saudáveis representam negócios saudáveis, com melhores lucros e maior retorno do investimento [...]” (MIYAMOTO et al. ,1999, p. 90). Destarte, “[...], somente as organizações que priorizem seus colaboradores com programas estruturados de gestão de pessoas se tornarão diferenciadas no século XXI [...]” (LIMA; STEFANO; ZAMPIER, 2011, p.110).

Nessa perspectiva, a qualidade de vida no trabalho (QVT) pode ser analisada como uma ferramenta de gestão (VASCONCELOS, 2001). A QVT atua na valorização das condições de trabalho, abrangendo os procedimentos da tarefa em si, o ambiente físico e os padrões de relacionamento (LIMONGI-FRANÇA, 1996).

Nesse sentido, Merlo et al. (2012, p. 107) afirma que:

"estudar apenas as patologias diagnosticáveis produziria um resultado muito aquém
da verdadeira situação de saúde desses servidores. Pode-se dizer que as patologias
diagnosticáveis são a pequena parte visível de um enorme iceberg, que esconde sob a
água uma parte muitas vezes maior, que é o sofrimento psíquico relacionado ao
trabalho. Para se poder estabelecer políticas de promoção e prevenção à saúde
adequadas no trabalho, é necessário identificar, da forma mais precoce possível, as 
fontes da agressão à saúde que possam levar ao adoecimento e que não são visíveis aos instrumentos tradicionais da clínica médica ou psicológica."

Nesse sentido, de acordo com Levi (1988), os esforços no sentido da melhoria do ambiente de trabalho, e na proteção e melhoria da saúde e do bem-estar dos trabalhadores devem se basear em um conceito amplo do indivíduo e do seu ambiente, e também em critérios ecológico, cibernético e democrático, conforme disposto no Quadro 5.

\section{Quadro 5 - Melhoria do ambiente laboral}

\begin{tabular}{|l|l|}
\hline \multicolumn{2}{|c|}{ Melhoria do ambiente laboral } \\
\hline $\begin{array}{l}\text { Conceito amplo do } \\
\text { indivíduo e do seu } \\
\text { ambiente }\end{array}$ & $\begin{array}{l}\text { Consideração justa e abrangente dos aspectos físicos, mentais, sociais e econômicos, } \\
\text { considerando o trabalhador e a situação de trabalho do ponto de vista médico, psicológico, } \\
\text { tecnológico e econômico; }\end{array}$ \\
\hline Critério ecológico & $\begin{array}{l}\text { Consideração da interação entre o indivíduo, em sua totalidade, e de todo o ambiente } \\
\text { (físico, químico e psicossocial), bem como da dinâmica desse sistema complexo, ou seja, } \\
\text { considerando completamente todos os componentes do ecossistema pessoa-ambiente; }\end{array}$ \\
\hline Critério cibernético & $\begin{array}{l}\text { Monitoramento e avaliação contínua acerca dos efeitos físicos, mentais, sociais e } \\
\text { econômicos que o ambiente laboral exerce sobre o trabalhador, bem como das mudanças } \\
\text { relacionadas a ele. Isso significa que todos os processos e atividades empreendidos sejam } \\
\text { acompanhados e avaliados de forma interdisciplinar; }\end{array}$ \\
\hline $\begin{array}{l}\text { Critério } \\
\text { democrático }\end{array}$ & $\begin{array}{l}\text { Permitir ao trabalhador a máxima influência possível sobre a sua própria situação, bem } \\
\text { como a construção de canais de comunicação diretos e eficientes entre o trabalhador e o } \\
\text { nível gerencial. Possibilitando aos trabalhadores, individualmente ou em grupo, a } \\
\text { participação na formulação e execução de decisões. }\end{array}$ \\
\hline
\end{tabular}

Fonte: Adaptado de Levi (1988, p. 167-168).

O Quadro 6 reforça o entendimento de que a QVT pode ser analisada com base nas abordagens de sistemas de qualidade, saúde e segurança no trabalho, e potencial humano. Ela ainda pode ser compreendida a nível individual, grupal e organizacional (LIMONGIFRANÇA, 1996).

“A construção da Qualidade de Vida no Trabalho ocorre a partir do momento em que se olham as pessoas como um todo, o que chamamos de enfoque biopsicossocial" (LIMONGI-FRANÇA, 1996, p.146). O conceito biopsicossocial fundamenta-se na visão holística do indivíduo, ou seja, entende a pessoa como um ser que possui potencialidades biológicas, psicológicas e sociais que respondem simultaneamente às situações vivenciadas (LIMONGI-FRANÇA, 1996). No Quadro 6 estão descritos estes três níveis. 
Quadro 6 - Enfoque biopsicossocial do ser humano

\begin{tabular}{|l|l|}
\hline \multicolumn{1}{|c|}{ Nível } & \multicolumn{1}{c|}{ Descrição } \\
\hline Biológico & $\begin{array}{l}\text { Refere-se às características físicas herdadas ou adquiridas ao nascer e ao longo da vida, tais como } \\
\text { metabolismo, resistências e vulnerabilidades dos sistemas e órgãos. }\end{array}$ \\
\hline Psicológico & $\begin{array}{l}\text { Refere-se aos processos afetivos, emocionais e de raciocínio, conscientes ou inconscientes, que } \\
\text { formam a personalidade de cada indivíduo e a sua maneira de perceber e se posicionar diante das } \\
\text { pessoas e das situações vivenciadas. }\end{array}$ \\
\hline Social & $\begin{array}{l}\text { Refere-se aos valores, às crenças, ao papel da família, no trabalho e nos círculos sociais que cada } \\
\text { pessoa pertence e participa. }\end{array}$ \\
\hline
\end{tabular}

Fonte: Adaptado de (LIMONGI-FRANÇA, 1996, p.146).

Tem-se ainda que "[...] há três elementos que fundamentam a qualidade de vida: a subjetividade, a multidimensionalidade e por último, a presença de dimensões positivas caracterizadas pela mobilidade e as negativas caracterizadas pela dor" (PAZINI; STEFANO, 2009, p. 4).

Nesse sentido, de acordo com Limongi-França (1996, p.149), “O stress é, talvez, a melhor medida do estado de bem-estar obtido ou não pela pessoa, isto é, a qualidade de vida no trabalho é individualizada na pessoa por meio de suas diferentes manifestações de stress".

Nessa perspectiva, tendo-se em vista que "A presença de estresse minimiza a qualidade de vida das pessoas, afetando o seu comportamento nos diferentes âmbitos de sua vida, sobretudo, no âmbito profissional [...]” (GOULART JUNIOR et al., 2014, p. 05), e que "Os estressores ocupacionais presentes nos contextos de trabalho afetam diretamente a saúde e bem-estar do trabalhador e precisam se reconhecidos e minimizados [...]" (GOULART JUNIOR et al., 2014, p. 07), faz-se necessário que as organizações implementem ações no sentido de reduzir os fatores estressores relacionados ao estresse ocupacional.

Os programas organizacionais para lidar com o estresse podem ser voltados para: a ginástica laboral; uma comunicação positiva; a maturidade de interação; a educação alimentar; o arranjo físico/ambiente; a corresponsabilidade e critérios e modelos legitimados (LIMONGI-FRANÇA; RODRIGUES, 2007).

Em relação às estratégias de controle do stress, elas "se dividem basicamente em dois tipos: (a) as de curto prazo que visam à redução dos sintomas e do desconforto gerado pela tensão e (b) as de longo prazo que almejam eliminar ou gerenciar as causas do stress" (LIPP; MALAGRIS; NOVAIS, 2007, p. 76). De acordo com Santos (2008), os programas de gestão de estresse também podem ser individuais ou organizacionais. “[...] O programa individual é dirigido a ajudar pessoas que já estão sofrendo de estresse, enquanto que os programas organizacionais atuam numa perspectiva mais preventiva, reduzindo os estressores, reais ou potenciais" (SANTOS, 2008, p. 64).

Nesse sentido, Santos (2008) ressalta que é necessário agir nas causas do estresse, 
atuando nos fatores que provocam o estresse nocivo. Desse modo, as estratégias de longo prazo são as que efetivamente resolvem os problemas relacionados ao estresse, identificando as fontes estressoras e eliminando as que forem possíveis de serem eliminadas (LIPP; MALAGRIS; NOVAIS, 2007).

Têm-se ainda alguns pontos que devem ser lembrados para um gerenciamento adequado do estresse: o estresse supõe um determinado estado psicofisiológico do organismo; o estresse implica numa interação entre o indivíduo e o ambiente; em certas circunstâncias, o estresse implica num estado de frustração ou conflitos graves; o estresse interfere no trabalho, diminuindo a produtividade e a atenção; o estresse afeta a integridade do organismo, podendo gerar sensações boas ou doenças e acidentes (SANTOS, 2008).

Diante do referencial apresentado, percebe-se que estresse pode trazer uma série de impactos negativos para as organizações e para os indivíduos, desse modo, aquelas necessitam possuir uma gestão de qualidade de vida bem estruturada a fim de conseguir gerenciar o problema de maneira adequada. Na seção primária seguinte, é apresentado o método de pesquisa empregado neste estudo. 


\section{MÉTODO DE PESQUISA}

Neste capítulo é apresentado o método de pesquisa, composto dos seguintes tópicos: a) classificação da pesquisa; b) categorias de análise; c) coleta de dados; d) unidade de análise; e) público de análise; f) instrumentos utilizados.

Nesta seção secundária, serão expostos o método de abordagem, a forma de pesquisa, e os objetivos metodológicos adotados neste estudo, o qual possui o método de abordagem dedutivo, a forma de enfoque quantitativa e objetivo metodológico descritivo.

\subsection{CLASSIFICAÇÃO DA PESQUISA}

Este estudo possui o método de abordagem dedutivo, no qual o pesquisador se baseia nas teorias preexistentes para construir as suas hipóteses de estudo (LEÃO; MELLO; VIEIRA, 2009). Nesse sentido, "No método dedutivo, a racionalização ou a combinação de ideias em sentido interpretativo têm mais valor que a experimentação caso a caso, ou seja, utiliza-se a dedução, raciocínio que caminha do geral para o particular" (KAUARK; MANHÃES; MEDEIROS, 2010, p. 67).

Desse modo, este estudo parte dos conhecimentos teóricos existentes acerca dos fatores estressores ocupacionais buscando-se identificar as causas geradoras do estresse ocupacional na população pesquisada.

Em relação ao tipo de pesquisa, é uma abordagem quantitativa. A pesquisa quantitativa busca “[...] fazer uma mensuração precisa de algo [...] (COOPER; SCHINDLER, 2011, p. 166), nesse tipo de estudo “[...] o pesquisador conduz seu trabalho a partir de um plano estabelecido a priori, com hipóteses claramente especificadas e variáveis operacionalmente definidas" (GODOY, 1995, p. 58).

Desse modo, "[...] metodologias quantitativas normalmente medem comportamento, conhecimento, opiniões ou atitudes [...]” (COOPER; SCHINDLER, 2011, p. 166). Esse tipo de metodologia preocupa-se com a medição objetiva e a quantificação dos resultados, além de buscar a precisão, a fim de que sejam evitados quaisquer tipos de distorções na análise e interpretação dos dados coletados e utilizados (GODOY, 1995, p. 58).

Nessa perspectiva, os dados quantitativos “[...] costumam consistir em respostas de participantes que são codificadas, categorizadas e reduzidas a números para que esses dados possam ser manipulados por análise estatística [...]" (COOPER; SCHINDLER, 2011, p. 166). 
Assim, nesta pesquisa, os dados coletados acerca dos fatores estressores relacionados às atividades profissionais desempenhadas pelos oficiais de justiça avaliadores federais serão quantificados para realização de testes estatísticos que permitam aferir a existência, ou não, de diferenças significativas entre os constructos e grupos de respondentes.

Por fim, o objetivo metodológico é descritivo. Esse tipo de estudo descreve aspectos ou comportamentos da população estudada, ou seja, elas identificam, relatam, comparam, entre outros aspectos (RAUPP; BEUREN, 2006).

\subsection{CATEGORIAS DE ANÁLISE E INSTRUMENTO}

Neste estudo, as categorias de análise utilizadas estão descritas no Quadro 7, que são os constructos constantes no questionário aplicado

\section{Quadro 7 - Categorias de análise utilizadas no instrumento de coleta de dados.}

\begin{tabular}{|l|l|}
\hline $\begin{array}{l}\text { Sobrecarga de } \\
\text { trabalho }\end{array}$ & $\begin{array}{l}\text { Buscou identificar se, na opinião dos respondentes, a carga de trabalho é adequada ou } \\
\text { excessiva. }\end{array}$ \\
\hline $\begin{array}{l}\text { Ameaça/agressão/ } \\
\text { violência }\end{array}$ & $\begin{array}{l}\text { Visou identificar se os pesquisados já sofreram algum tipo de ameaça, violência ou agressão } \\
\text { verbal e/ou física no desempenho do trabalho, bem como se já tiveram algum bem danificado } \\
\text { ou roubado no exercício da profissão. }\end{array}$ \\
\hline Comunicação & Buscou identificar se a comunicação dentro da organização ocorre de maneira fácil. \\
\hline $\begin{array}{l}\text { Atividades mais } \\
\text { desgastantes }\end{array}$ & $\begin{array}{l}\text { Visou identificar quais as atividades que os pesquisados consideram mais desgastantes na sua } \\
\text { profissão. }\end{array}$ \\
\hline
\end{tabular}

Fonte: Elaborado pelos autores

A partir das categorias descritas no Quadro 7, a pesquisa buscou realizar a coleta de dados de maneira que os objetivos da pesquisa fossem respondidos, identificando-se, por exemplo, a existência ou não de sobrecarga de trabalho, ameaça/agressão/violência no trabalho.

O questionário aplicado foi composto de 55 questões, sendo 50 objetivas e 05 discursivas. A partir da questão 18 , exceto a questão 41, foi utilizada uma escala Likert variando de 1 a 5 pontos. O instrumento utilizado foi adaptado de Zille (2005), Rezende (2010) e Merlo et al. (2012), conforme apêndice.

\subsection{COLETA DE DADOS}

Em uma pesquisa, as fontes de dados primárias são aquelas que os dados coletados gerarão análises que permitirão a criação de informações posteriormente. Já as fontes de dados secundárias são aquelas em que os dados coletados já sofreram algum tipo de 
tratamento, ou seja, as informações já foram elaboradas (KAUARK; MANHÃES; MEDEIROS, 2010).

A pesquisa envolveu a coleta de dados primários como questionários. Foi utilizado questionário estruturado disfarçado, em que não foram identificados os constructos de pesquisa, e auto preenchidos (Apêndice A), aplicados com a utilização do google drive, e encaminhados para o e-mail da população pesquisada. Também foram utilizadas informações constantes em trabalhos publicados acerca de temas relacionados à qualidade de vida no trabalho que tenham sido efetuados junto aos Oficiais de Justiça Avaliadores Federais.

Nesse sentido, os dados primários utilizados neste estudo foram os coletados no instrumento aplicado junto aos Oficiais de Justiça Avaliadores Federais. Desse modo, a coleta de dados foi realizada por meio de questionário, o qual compõe-se de questões aderentes ao Modelo Teórico de Explicação do Estresse Ocupacional em Gerentes (MTEG), desenvolvido por Zille (2005), bem como questões constantes no estudo de Merlo et al. (2012).

A coleta de dados foi realizada por meio do Google Drive e contou-se com a colaboração da Assojaf PR (Associação dos Oficiais de Justiça Avaliadores Federais do Estado do Paraná) e da Assojaf MG (Associação dos Oficiais de Justiça Avaliadores Federais em Minas Gerais). O link contendo o questionário foi encaminhado para as supramencionadas Associações, que o reencaminharam para os Oficiais de Justiça Avaliadores Federais associados.

A coleta de dados ocorreu no período de 21 de dezembro de 2015 a 30 de janeiro de 2016, não havendo prorrogação no prazo de coleta.

\subsection{UNIDADE DE ANÁLISE}

Em relação à preocupação do Poder Judiciário Federal com a gestão da qualidade de vida no trabalho, tem-se que em 2014, durante o VIII Encontro Nacional do Poder Judiciário, foi aprovada a seguinte Diretriz Estratégica para orientar a atuação do Judiciário brasileiro em 2015: “É diretriz estratégica, aplicável a todos os órgãos do Poder Judiciário, zelar pelas condições de saúde de magistrados e servidores, com vistas ao bem-estar e à qualidade de vida no trabalho" (CNJ, 2015).

A pesquisa foi efetuada junto aos oficiais de justiça avaliadores federais, associados à Assojaf MG ou Assojaf PR e atuantes nos Estados de Minas Gerais (MG) ou Paraná (PR). Desse modo, foi aplicado um questionário (Apêndice A) para estes servidores, obtendo-se 88 respondentes. A Assojaf MG e Assojaf PR possuem 310 e 230 associados, respectivamente. 


\subsection{SÍNTESE DO MÉTODO DE PESQUISA}

Nesta seção secundária, são apresentados, sinteticamente, os métodos de pesquisa utilizados nesta dissertação, conforme exposto no Quadro 8, a seguir:

\section{Quadro 8- Síntese do método de pesquisa da dissertação}

\begin{tabular}{|l|l|}
\hline Categorias/Aspectos & Etapas \\
\hline Objetivo Geral & $\begin{array}{l}\text { Identificar os fatores ocupacionais que causam estresse na atividade } \\
\text { profissional dos Oficiais de Justiça Avaliadores Federais. }\end{array}$ \\
\hline Características da Pesquisa & Descritiva, de abordagem dedutiva e enfoque quantitativo. \\
\hline Dimensão de Tempo & Ocasional único. \\
\hline Natureza das Variáveis & $\begin{array}{l}\text { Quantitativa: Dados primários decorrentes da aplicação de questionário junto } \\
\text { aos oficiais de justiça avaliadores federais que compõe o quadro da } \\
\text { organização. }\end{array}$ \\
\hline Meios de Investigação & Levantamento, survey. \\
\hline $\begin{array}{l}\text { Critérios de Seleção da organização } \\
\text { Pesquisada }\end{array}$ & $\begin{array}{l}\text { A Assojaf PR e a Assojaf MG se disponibilizaram em colaborar com a } \\
\text { pesquisa. }\end{array}$ \\
\hline População da Pesquisa & $\begin{array}{l}\text { Oficiais de Justiça Avaliadores Federais associados à Assojaf PR ou a } \\
\text { Assojaf MG, lotados na capital, região metropolitana e interior do Estado. }\end{array}$ \\
\hline $\begin{array}{l}\text { Critérios de Seleção do Público } \\
\text { Alvo }\end{array}$ & Método não probabilístico, por conveniência. \\
\hline Instrumento de Pesquisa & Questionário Estruturado (Apêndice A). \\
\hline Coleta de Dados & $\begin{array}{l}\text { Por meio de questionário estruturado. No período de 21 de dezembro de } \\
\text { 2015 a 30 de janeiro de 2016. }\end{array}$ \\
\hline Técnica de Análise de Dados & $\begin{array}{l}\text { Análises quantitativas, envolvendo estatística descritiva do perfil dos } \\
\text { respondentes. }\end{array}$ \\
\hline
\end{tabular}

Fonte: Elaborado pelos autores

O Quadro 8 foi construído objetivando-se permitir uma maior compreensão acerca do estudo desenvolvido.

Nesse sentido, a fim de embasar cientificamente o que vem sendo constatado in loco ou por meio de relatos dos servidores, o Sindicato dos Trabalhadores do Judiciário Federal no Rio Grande do Sul (SINTRAJUFE RS) vem realizando pesquisas quantitativas e qualitativas junto ao quadro funcional, e tem identificado uma queda significativa na qualidade de vida dos servidores envolvendo sofrimento psíquico e adoecimento físico. Um destes estudos, realizado por meio da construção de uma parceria entre o Sintrajufe e a Universidade Federal do Rio Grande do Sul, pesquisou os Oficiais de Justiça da Justiça Federal lotados na Central de Mandados de Porto alegre e buscou investigar as consequências provocadas pelo trabalho na saúde destes profissionais (SINTRAJUFE RS, 2013). 


\section{ANÁLISE DOS RESULTADOS DA PESQUISA}

A Lei No 13.105, de 16 de março de 2015 (novo Código de Processo Civil), dispõe como atribuições dos Oficiais de Justiça Avaliadores Federais:

Art. 154. Incumbe ao oficial de justiça:

I - fazer pessoalmente citações, prisões, penhoras, arrestos e demais diligências próprias do seu ofício, sempre que possível na presença de 2 (duas) testemunhas, certificando no mandado o ocorrido, com menção ao lugar, ao dia e à hora;

II - executar as ordens do juiz a que estiver subordinado;

III - entregar o mandado em cartório após seu cumprimento;

IV - auxiliar o juiz na manutenção da ordem;

$\mathrm{V}$ - efetuar avaliações, quando for o caso;

VI - certificar, em mandado, proposta de auto composição apresentada por qualquer das partes, na ocasião de realização de ato de comunicação que lhe couber.

Parágrafo único. Certificada a proposta de auto composição prevista no inciso VI, o juiz ordenará a intimação da parte contrária para manifestar-se, no prazo de 5 (cinco) dias, sem prejuízo do andamento regular do processo, entendendo-se o silêncio como recusa.

Art. 255. Nas comarcas contíguas de fácil comunicação e nas que se situem na mesma região metropolitana, o oficial de justiça poderá efetuar, em qualquer delas, citações, intimações, notificações, penhoras e quaisquer outros atos executivos.

Art. 782. Não dispondo a lei de modo diverso, o juiz determinará os atos executivos, e o oficial de justiça os cumprirá.

$\S 1$ o $\mathrm{O}$ oficial de justiça poderá cumprir os atos executivos determinados pelo juiz também nas comarcas contíguas, de fácil comunicação, e nas que se situem na mesma região metropolitana.

Para a análise dos fatores estressores entre os trabalhadores, o perfil sócio demográfico, como gênero, idade, escolaridade, dentre outros, colabora no entendimento acerca do assunto. Desse modo, identificou-se que a maior parte da amostra declarou ser do sexo masculino, ter idade entre 31 e 40 anos, atuar como Oficial de Justiça de 11 a 20 anos, possuir pós-graduação completa, não exercer outra atividade profissional, ser casado ou ter uma união estável e estar lotado no interior do Estado. 


\section{Gráfico 1 - Sexo da Amostra (\%)}
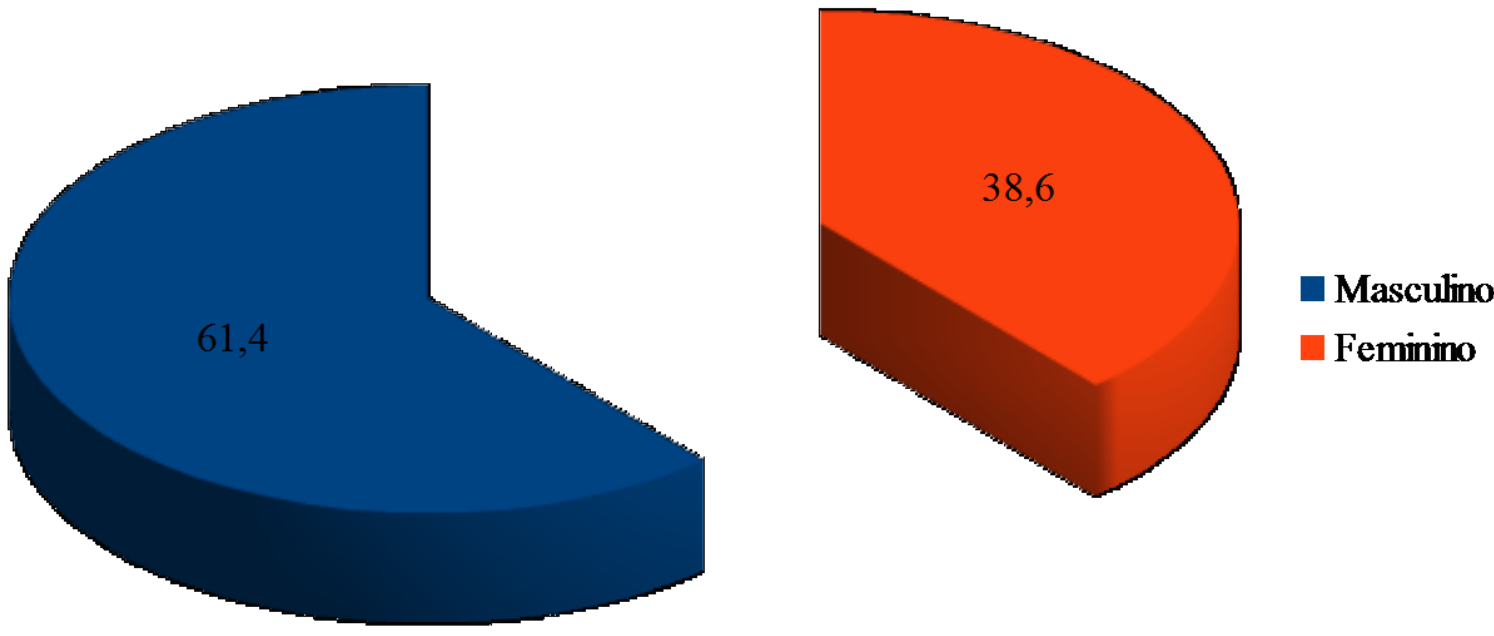

Fonte: Elaborado pelos autores com dados coletados na pesquisa de campo (2016).

O Gráfico 1 evidencia o sexo da amostra pesquisada. Observa-se que há uma predominância do sexo masculino (mais de $60 \%$ dos respondentes). A predominância deste sexo também pode ser observada na pesquisa de Merlo et al. (2012) com Oficiais de Justiça no Rio Grande do Sul (54,3\% dos participantes eram homens). Desse modo, outros estudos tendo como população os Oficiais de Justiça Avaliadores Federais contribuiriam no sentido de se identificar se a predominância do sexo masculino é uma característica dessa profissão. 


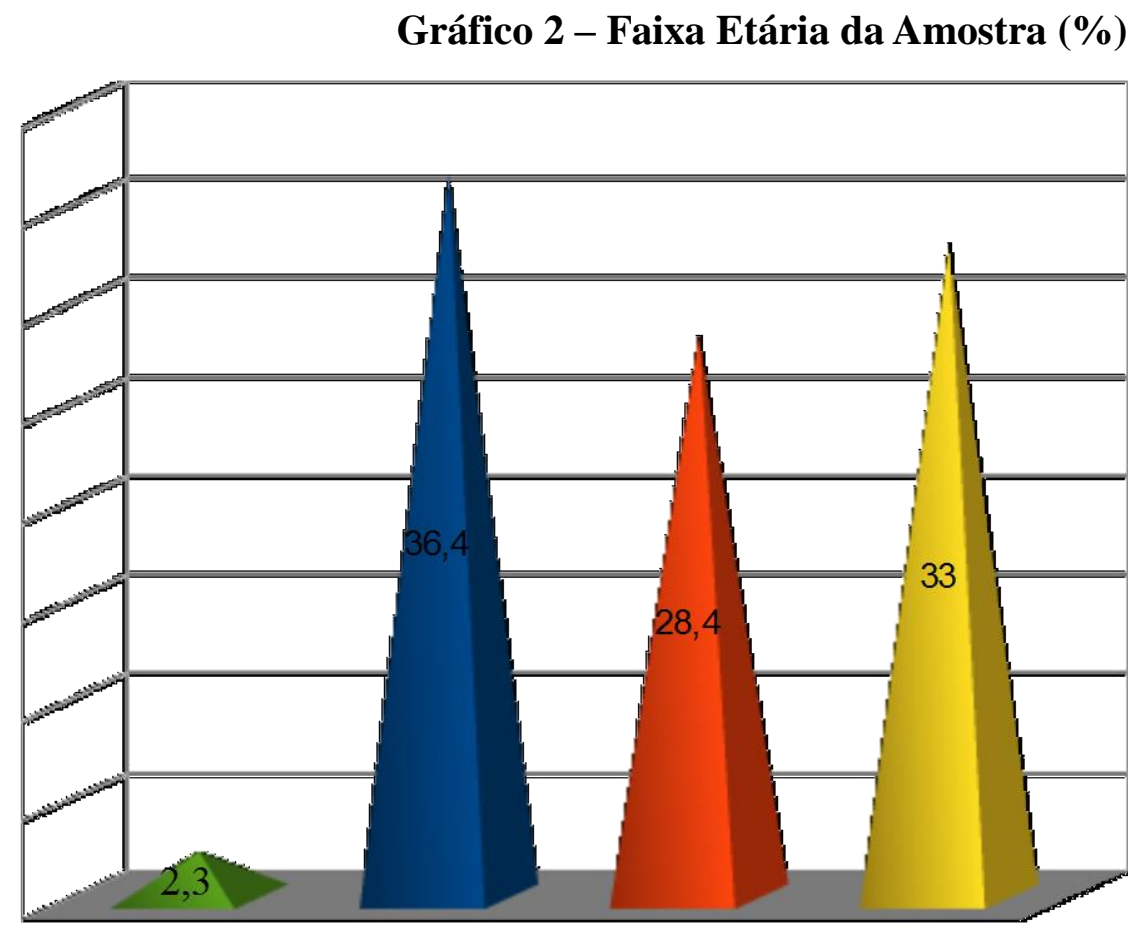

Acima de 50 anos

$\square$ De 41 a 50 anos

De 31 a 40 anos

Até 30 anos

Fonte: Elaborado pelos autores com dados coletados na pesquisa de campo (2016).

O Gráfico 2 mostra que a maior parte da amostra está situada na faixa etária de 31 a $40 \operatorname{anos}(36,4 \%)$.

Gráfico 3 - Estado Civil da Amostra (\%)

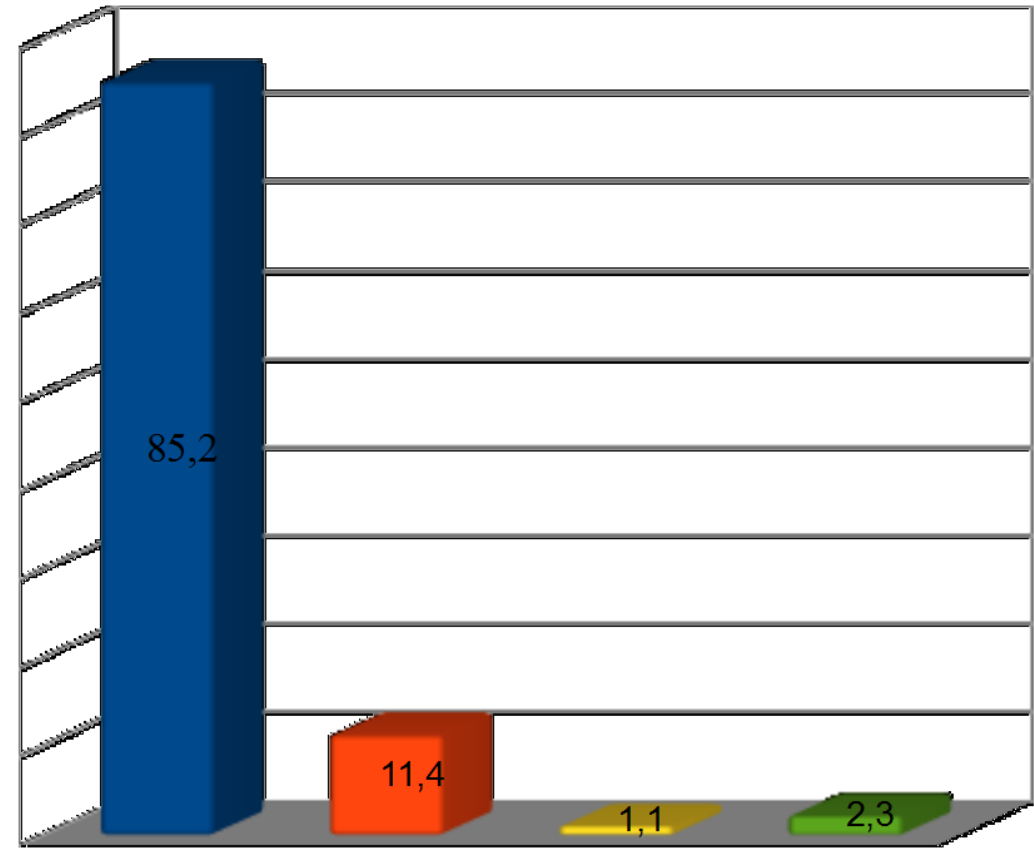

Divorciado(a)

Viúvo(a)

Solteiro(a)

casado(a)/União Estável

Fonte: Elaborado pelos autores com dados coletados na pesquisa de campo (2016). 
No Gráfico 3, nota-se que $85,2 \%$ dos indivíduos que participaram da pesquisa indicaram ser casado (a) ou estar numa união estável. Talvez o estado civil predominante esteja relacionado com a faixa etária da amostra, composta em sua maioria por indivíduos de 31 a 40 anos.

\section{Gráfico 4 - Tempo de Trabalho da Amostra (\%)}

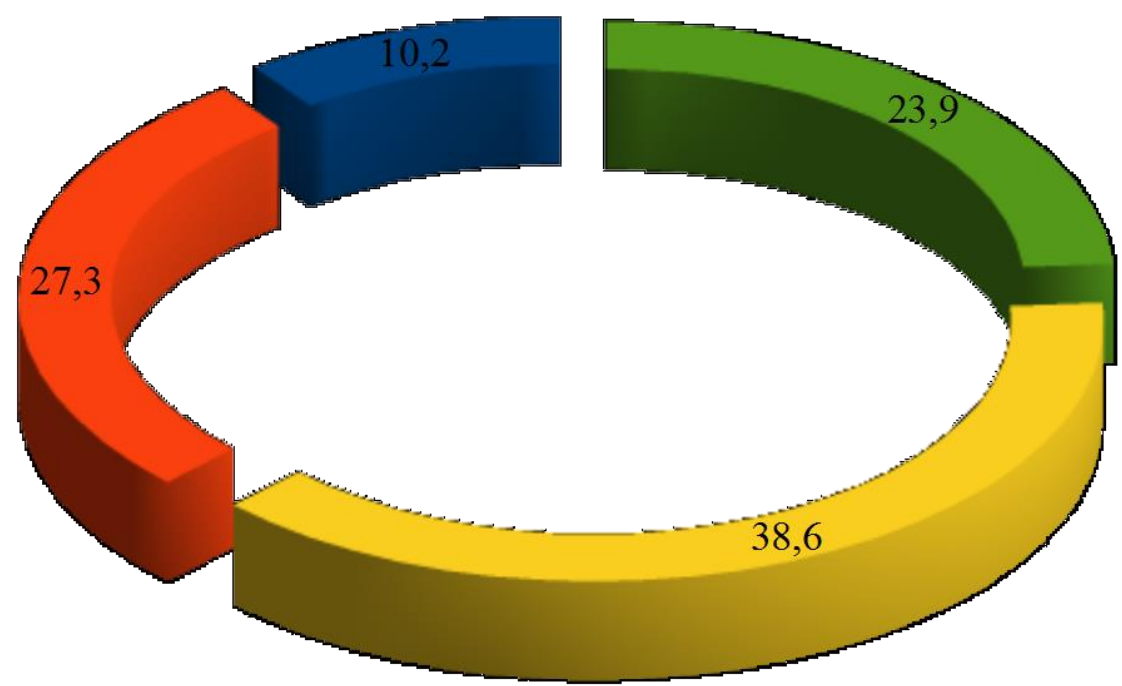

- Até 05 anos

De 06 a 10 anos

De 11 a 20 anos

Acima de 20 anos

Fonte: Elaborado pelos autores com dados coletados na pesquisa de campo (2016).

Como pode ser observado no Gráfico 4, 38,6\% da amostra exerce o cargo de Oficial de Justiça Avaliador Federal de 11 a 20 anos. 
Gráfico 5 - Nível de Instrução da Amostra (\%)

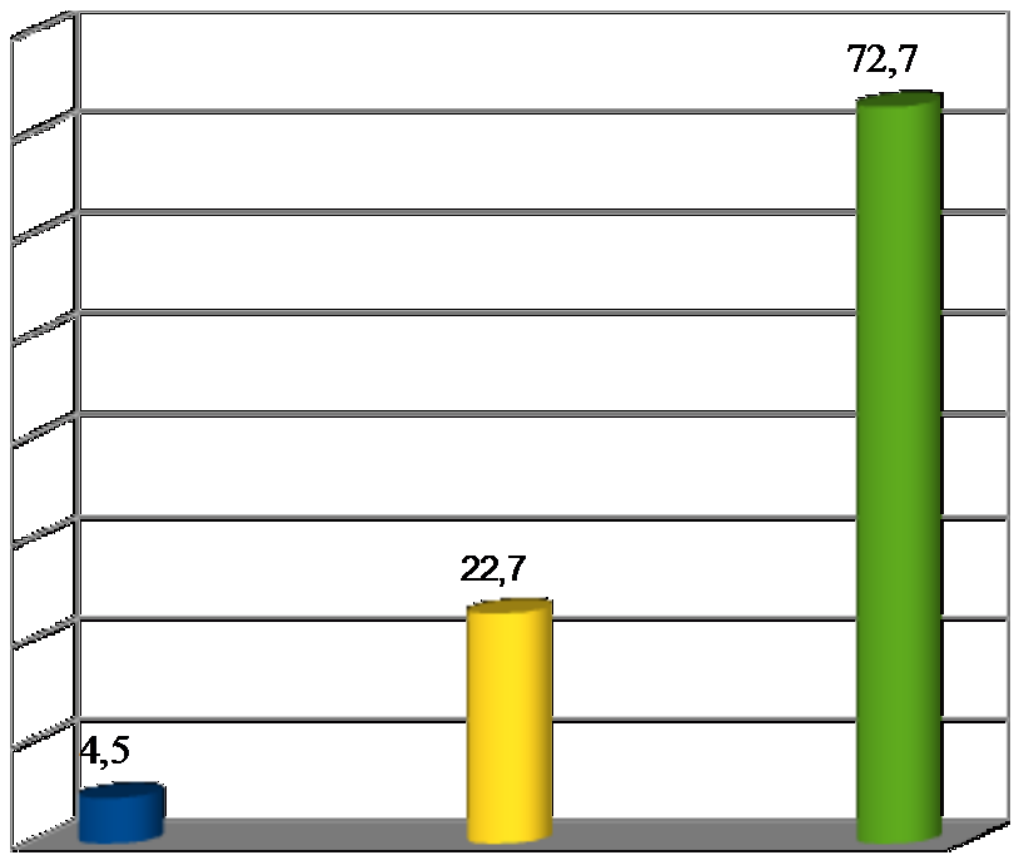

Mestrado Completo Superior Completo Pós-graduação completa

Fonte: Elaborado pelos autores com dados coletados na pesquisa de campo (2016).

O Gráfico 5 mostra que a maior parte dos respondentes indicaram possuir pósgraduação completa $(72,7 \%)$. Talvez, esse nível de escolaridade se justifique em razão de a lei N ${ }^{\mathrm{o}}$ 11.416, de 15 de dezembro de 2006, que dispõe sobre as carreiras dos servidores do Poder Judiciário da União, prever um adicional de qualificação de 7,5\% sobre o vencimento básico do servidor, em se tratando de certificado de especialização.

Também foi identificado que 96,6\% dos Oficiais de Justiça que participaram da pesquisa afirmaram não exercer outra atividade profissional além da desenvolvida no Poder Judiciário Federal, enquanto 3,4\% indicaram o oposto. 


\section{Gráfico 6 - Localidade de Lotação da Amostra (\%)}
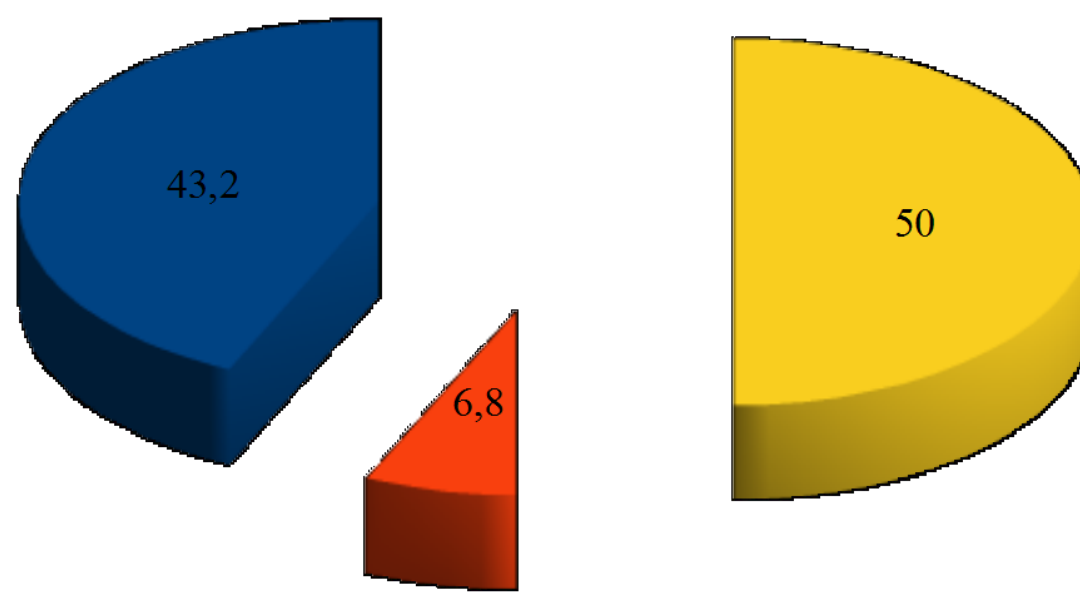

Capital

Região Metropolitana

Interior

Fonte: Elaborado pelos autores com dados coletados na pesquisa de campo (2016).

Metade da amostra pesquisada (50\%) afirmou que está lotada no interior do Estado em que labora, como pode ser observado no Gráfico 6.

Sintetizando, tem-se que a maior parte da amostra declarou ser do gênero masculino, ter idade entre 31 e 40 anos, atuar como Oficial de Justiça de 11 a 20 anos, possuir pósgraduação completa, não exercer outra atividade profissional, ser casado ou estar numa união estável e estar lotado no interior do Estado.

Tabela 1 - Ameaça/Agressão/Violência Sofrida pela Amostra no Exercício da Profissão

\begin{tabular}{c|l|c|c|c|c}
\hline \multicolumn{2}{c|}{} & Frequência & Porcentual & Porcentagem Válida & Porcentagem Acumulativa \\
\hline \multirow{5}{*}{ Válido } & Verbal & 65 & 73,9 & 73,9 & 73,9 \\
\cline { 2 - 6 } & Física & 2 & 2,3 & 2,3 & 76,1 \\
\cline { 2 - 6 } & Verbal e Física & 16 & 18,2 & 18,2 & 94,3 \\
\cline { 2 - 6 } & Não & 5 & 5,7 & 5,7 & 100,0 \\
\cline { 2 - 6 } & Total & 88 & 100,0 & 100,0 & \\
\hline
\end{tabular}

Fonte: Elaborado pelos autores com dados coletados na pesquisa de campo (2016).

Conforme exposto na Tabela 1, observa-se que 5,7\% dos respondentes afirmou não ter sofrido nenhum tipo de ameaça/violência/agressão verbal ou física no exercício da 
atividade profissional, enquanto que $73,9 \%$ da amostra afirmou já ter sofrido ameaça/violência/agressão verbal no exercício da função. Esses dados confirmam os apontamentos da Assojaf-GO $(2013 ; 2015)$ e de Merlo et al. (2012) no tocante a essa questão.

Isso encontra consonância com o que Merlo et al. (2012, p.108) descreve:

\begin{abstract}
"Nos relatos desses trabalhadores, é possível perceber que, para a instituição, a questão da violência a que estão expostos é considerada algo inerente à própria atividade. Há uma tendência à banalização, quase a uma "naturalização". No entanto, existem várias atividades nas quais os trabalhadores podem estar expostos a risco de violência e nas quais, diferentemente das forças policiais, não há uma preocupação de treinamento e prevenção constante. No caso dos oficiais de Justiça Federal, não há nenhum tipo de treinamento específico nem são tomadas medidas que possam limitar os riscos de exposição à violência."
\end{abstract}

Tabela 2 - Bem Particular Danificado ou Roubado no Exercício da Função

\begin{tabular}{c|l|c|c|c|c}
\hline \multicolumn{2}{c|}{} & Frequência & Porcentual & Porcentagem Válida & Porcentagem Acumulativa \\
\hline \multirow{5}{*}{ Válido } & Danificado & 40 & 45,5 & 45,5 & 45,5 \\
\cline { 2 - 6 } & Roubado & 5 & 5,7 & 5,7 & 51,1 \\
\cline { 2 - 6 } & Danificado e Roubado & 5 & 5,7 & 5,7 & 56,8 \\
\cline { 2 - 6 } & Não & 38 & 43,2 & 43,2 & 100,0 \\
\cline { 2 - 6 } & Total & 88 & 100,0 & 100,0 & \\
\hline
\end{tabular}

Fonte: Elaborado pelos autores com dados coletados na pesquisa de campo (2016).

A Tabela 2, mostra que $43,2 \%$ da amostra afirmaram não ter tido um bem particular danificado ou roubado no exercício da função, enquanto 45,5\% indicaram já ter tido um bem danificado no exercício da profissão. Dentre aqueles que afirmaram ter tido um bem danificado ou roubado, $68,2 \%$ afirmaram não ter tido seu prejuízo ressarcido pela administração. Nessa perspectiva, um estudo realizado com os Oficiais de Justiça da Justiça Federal, lotados na Central de Mandados de Porto alegre, que buscava investigar as consequências provocadas pelo trabalho na saúde destes profissionais, apontou que, dentre os pesquisados, no exercício da sua função, 63,8\% tiveram bens danificados e 38,8\% tiveram bens roubados (MERLO et al., 2012). Desse modo, tanto neste estudo quanto no de Merlo et al. (2012), mais de 45\% dos participantes declararam já ter tido algum bem danificado no exercício da atividade profissional. 
Tabela 3 - Segurança no Exercício da Função

\begin{tabular}{c|l|c|c|c|c}
\hline \multicolumn{2}{c|}{} & Frequência & Porcentual & Porcentagem Válida & Porcentagem Acumulativa \\
\hline \multirow{3}{*}{ Válido } & Sim & 10 & 11,4 & 11,4 & 11,4 \\
\cline { 2 - 6 } & Não & 78 & 88,6 & 88,6 & 100,0 \\
\cline { 2 - 6 } & Total & 88 & 100,0 & 100,0 & \\
\hline
\end{tabular}

Fonte: Elaborado pelos autores com dados coletados na pesquisa de campo (2016).

Em relação à sensação de segurança no exercício profissional, a Tabela 3 mostra que $88,6 \%$ dos respondentes afirmaram não se sentirem seguros durante o exercício da função. De acordo com os 77 indivíduos que responderam ao item discursivo "quais fatores mais contribuem para a insegurança no exercício da função", 41,56\% indicaram o trabalho solitário [confirmando o apontamento de Merlo et al. (2012, p. 108) de que "Os oficiais referem o caráter solitário como uma característica de seu trabalho [...]"], 19,48\% apontaram a falta de equipamento de proteção (andar desarmado) e 42,86\% indicaram a violência. Essas foram as respostas mais apontadas nesse item, sendo que o respondente podia indicar mais de um fator.

Nesse sentido, 97,10\% dos Oficiais de Justiça que participaram do estudo de Merlo et al. (2012) afirmaram que se sentem inseguros no exercício da função. De acordo com eles, o que mais contribui com a insegurança são os lugares perigosos $(77,9 \%)$, o trabalho solitário $(77,9 \%)$, a violência urbana em geral $(69,1 \%)$ e as situações conflitantes decorrentes do mandado (53,5\%) (SINTRAJUFE RS, 2013).

Desse modo, identifica-se que o trabalho solitário, andar desarmado e a violência urbana são os fatores mais indicados pelos respondentes como os que mais contribuem para a insegurança no Exercício da Função, confirmando o trabalho de Merlo et al. (2012) no tocante à sensação de insegurança no exercício da função e na contribuição do trabalho solitário e da violência para essa sensação de insegurança.

Tabela 4 - Recebeu treinamento para realizar as tarefas

\begin{tabular}{c|l|c|c|c|c}
\hline \multicolumn{2}{c|}{} & Frequência & Porcentual & Porcentagem Válida & Porcentagem Acumulativa \\
\hline \multirow{3}{*}{ Válido } & Não & 57 & 64,8 & 64,8 & 64,8 \\
\cline { 2 - 6 } & Sim & 31 & 35,2 & 35,2 & 100,0 \\
\cline { 2 - 6 } & Total & 88 & 100,0 & 100,0 & \\
\hline
\end{tabular}

Fonte: Elaborado pelos autores com dados coletados na pesquisa de campo (2016).

No tocante ao treinamento para a realização das atividades, a Tabela 4 aponta que, dentre os respondentes, 35,2\% afirmaram ter recebido treinamento para realizar as tarefas enquanto $64,8 \%$ informaram o oposto. Dentre aqueles que afirmaram ter recebido 
treinamento, 58,06\% informaram que o treinamento foi ofertado pela organização e 41,94\% indicou que foi treinado por outro colega de trabalho.

Nesse sentido, um estudo que objetivava identificar os efeitos do trabalho sobre a saúde de Oficiais da Justiça Federal de Porto Alegre identificou que um dos fatores de sofrimento apontado por eles foi a ausência de treinamento inicial para a execução da atividade. Segundo os respondentes do referido estudo, 90,1\% não recebeu treinamento inicial e, dos $9,9 \%$ que afirmou ter recebido treinamento, apenas $12,5 \%$ foi treinado por meio de curso ofertado pela administração, os outros $75,0 \%$ daqueles que receberam treinamento foram treinados por outro colega de trabalho e 12,5\% indicaram outra forma (MERLO et al., 2012). Desse modo, tanto neste estudo quanto na pesquisa de Merlo et al. (2012), mais de $60 \%$ dos respondentes apontaram não ter recebido treinamento para a execução das atividades realizadas. De acordo com o referido autor, "A falta de um treinamento inicial para a execução da atividade também é apontada como um fator de sofrimento, na medida em que aprendem sozinhos ou apenas com algum colega [...]" (MERLO et al., 2012, p.108).

Tem-se ainda que "[...] A ausência de uma política de educação continuada na instituição também é apontada como falha nas situações de mudança nas rotinas de trabalho, muitas vezes sem aviso prévio, para as quais os oficiais não são preparados com antecedência." (MERLO et al., 2012, p.108).

Em relação à utilização de aparelho telefônico particular, dentre os respondentes, $65,9 \%$ afirmaram utilizar o telefone celular particular no desempenho da sua atividade profissional e 34,1\% informaram o contrário.

Dentre os tipos de mandados considerados mais desgastantes pelos 88 indivíduos que responderam a este item, aparecem com maior frequência os mandados de imissão na posse $(15,91 \%)$, penhora $(43,18 \%)$ e remoção $(30,68 \%)$. Nesse sentido, para $25,3 \%$ dos participantes do estudo de Merlo et al., (2012) os mandados de penhora eram considerados uma das atividades mais penosas (SINTRAJUFE RS, 2013).

Quando indagados acerca da existência de outros fatores causadores de tensão excessiva no ambiente de trabalho, citou-se a falta de organização, o assédio moral, a falta de material de trabalho adequado, a ocupação de cargos de chefia por indivíduos sem a competência necessária e a ineficiência do sitema PJE (Processo Judicial Eletrônico), dentre outros. Nesse sentido, Sadir e Lipp afirmam que (2009, p.120) "[...] O funcionário que não tem conhecimento suficiente para exercer determinada função ou aquele que o tem, mas que não se propõe a ajudar o colega, proporciona situações de grande desgaste na empresa." 
Tabela 5 - Média, Desvio-Padrão e Coeficiente de Variação das variáveis.

\begin{tabular}{|c|c|c|c|}
\hline VARIÁVEIS & $\mathbf{M}$ & DP & $\begin{array}{l}\text { CV } \\
(\%)\end{array}$ \\
\hline $\begin{array}{l}\text { Q01-Executo um trabalho complexo, que me deixa desgastado (a) /muito } \\
\text { cansado (a). }\end{array}$ & 4,22 & 0,952 & 22,56 \\
\hline $\begin{array}{l}\text { Q02-A tecnologia do meu trabalho tem me sobrecarregado muito (ex: } \\
\text { mensagens eletrônicas, softwares, sistemas integrados, etc.). }\end{array}$ & 3,51 & 1,286 & 36,64 \\
\hline $\begin{array}{l}\text { Q03-O trabalho que executo consiste na realização de várias atividades ao } \\
\text { mesmo tempo, com alto grau de cobrança, o que gera em mim tensão em } \\
\text { excesso. }\end{array}$ & 3,91 & 1,190 & 30,43 \\
\hline $\begin{array}{l}\text { Q04-Percebo que a gestão da organização em que trabalho é excessivamente } \\
\text { pautada em resultados quantitativos (números) causando-me tensão excessiva. }\end{array}$ & 3,92 & 1,261 & 32,17 \\
\hline $\begin{array}{l}\text { Q05-É normal que as organizações queiram fazer mais com o mínimo, porém, } \\
\text { na organização em que atuo esta situação é exagerada, e o número de Oficiais } \\
\text { de Justiça que compõe o seu quadro funcional está muito abaixo do } \\
\text { necessário. }\end{array}$ & 4,14 & 1,157 & 27,94 \\
\hline $\begin{array}{l}\text { Q06-A organização em que trabalho estabelece metas de trabalho em excesso, } \\
\text { gerando grande desgaste na sua execução, acompanhamento e avaliação. }\end{array}$ & 3,63 & 1,244 & 34,27 \\
\hline $\begin{array}{l}\text { Q07-Grande parte das decisões relacionadas ao meu trabalho é tomada sem a } \\
\text { minha participação, o que causa em mim desgaste excessivo. }\end{array}$ & 3,72 & 1,339 & 35,99 \\
\hline $\begin{array}{l}\text { Q08-No desenvolvimento do meu trabalho, sofro pressão excessiva em seus } \\
\text { diversos aspectos. }\end{array}$ & 3,63 & 1,316 & 36,25 \\
\hline $\begin{array}{l}\text { Q09-A convivência com ocorrências de alto impacto emocional, deixa-me } \\
\text { tenso (a) no trabalho. }\end{array}$ & 4,16 & 1,103 & 26,51 \\
\hline $\begin{array}{l}\text { Q10-O risco de violência/agressão decorrente da minha atividade causa em } \\
\text { mim uma tensão excessiva. }\end{array}$ & 4,10 & 1,125 & 27,43 \\
\hline $\begin{array}{l}\text { Q11-Na organização em que trabalho existe a prática } \\
\text { isolar/perseguir pessoas que eventualmente } \\
\text { sejam }\end{array} \begin{array}{c}\text { reconte de } \\
\text { consideradas }\end{array}$ & 2,53 & 1,438 & 56,83 \\
\hline Q12-Há situações de desrespeito humano na organização em que trabalho. & 2,59 & 1,419 & 54,78 \\
\hline $\begin{array}{l}\text { Q13-Para atingir os resultados que a organização exige, muitas vezes, } \\
\text { defronto-me com situações em que há orientações superiores, explícitas ou } \\
\text { implícitas, para agir fora do que considero eticamente correto. }\end{array}$ & 2,44 & 1,405 & 57,58 \\
\hline $\begin{array}{l}\text { Q14-Muitos prazos, e prazos apertados, são rotina no meu trabalho, } \\
\text { acarretando-me grande incômodo e tensão excessiva. }\end{array}$ & 3,98 & 1,250 & 31,40 \\
\hline $\begin{array}{l}\text { Q15-As minhas atividades, na organização em que trabalho, geram uma } \\
\text { excessiva carga de trabalho, o que, de certa forma, está ultrapassando os meus } \\
\text { limites e gerando significativa fonte de tensão em mim. }\end{array}$ & 3,63 & 1,307 & 36,00 \\
\hline $\begin{array}{l}\text { Q16-Conheço o que é qualidade de vida no trabalho, bem como sua } \\
\text { importância, mas não tenho tempo de praticar esses conceitos devido à } \\
\text { absorção pelo trabalho. }\end{array}$ & 3,57 & 1,276 & 35,74 \\
\hline $\begin{array}{l}\text { Q17-Tenho dificuldade de compatibilizar os compromissos de trabalho com os } \\
\text { compromissos de família, sociais, entre outros. }\end{array}$ & 3,13 & 1,388 & 44,34 \\
\hline $\begin{array}{l}\text { Q18-Vivencio conflitos por estar em sobrecarga, mas não ter como questioná- } \\
\text { la. }\end{array}$ & 3,36 & 1,408 & 41,90 \\
\hline $\begin{array}{l}\text { Q19-Convivo com situações de tensão excessiva inerente às relações humanas } \\
\text { no trabalho. }\end{array}$ & 3,31 & 1,496 & 45,19 \\
\hline $\begin{array}{l}\text { Q20-Na organização em que trabalho, há um canal aberto de comunicação } \\
\text { para discussão das situações de dificuldade e tensão vivenciadas. }\end{array}$ & 2,38 & 1,280 & 53,78 \\
\hline $\begin{array}{l}\text { Q21-Percebo que na organização em que atuo há uma colaboração dos colegas } \\
\text { de trabalho na execução das tarefas desempenhadas. }\end{array}$ & 3,40 & 1,291 & 37,97 \\
\hline Q22-O trânsito me deixa tensionado excessivamente. & 3,88 & 1,230 & 31,70 \\
\hline $\begin{array}{l}\text { Q23-Os endereços incompletos ou insuficientes, constantes nos mandados, me } \\
\text { causam tensão excessiva. }\end{array}$ & 4,20 & 1,105 & 26,30 \\
\hline $\begin{array}{l}\text { Q25-Sinto que a quantidade de trabalho a ser executado aumentou nos últimos } \\
05 \text { anos. }\end{array}$ & 4,42 & 1,003 & 22,69 \\
\hline $\begin{array}{l}\text { Q26-Sinto que a dificuldade de realizar o meu trabalho aumentou nos últimos } \\
05 \text { anos. }\end{array}$ & 4,06 & 1,207 & 29,72 \\
\hline Q27-Percebo que há competitividade entre o & 2,55 & 1,405 & 55,09 \\
\hline
\end{tabular}




\begin{tabular}{l|r|r|r}
\hline $\begin{array}{l}\text { Q28-A maioria dos Diretores de Vara procura a minha colaboração quando } \\
\text { existem decisões que influem no cumprimento do mandado. }\end{array}$ & 2,02 & 1,398 & 69,20 \\
\hline $\begin{array}{l}\text { Q29-A maioria dos Diretores de Vara explica o motivo das ordens e das } \\
\text { decisões importantes. }\end{array}$ & 1,82 & 1,246 & 68,46 \\
\hline Q30-Eu me sinto respeitado pela maioria dos Diretores de Vara. & 2,73 & 1,444 & 52,89 \\
\hline $\begin{array}{l}\text { Q31-O(A) Juiz(a) conversa comigo, previamente, sobre o teor da ordem } \\
\text { existente no mandado. }\end{array}$ & 1,36 & 0,985 & 72,42 \\
\hline $\begin{array}{l}\text { Q32-Os bons resultados alcançados por mim em meu trabalho são } \\
\text { reconhecidos pela organização em que trabalho. }\end{array}$ & 2,05 & 1,249 & 60,92 \\
\hline $\begin{array}{l}\text { Q33-Eu me sinto seguro (a) tecnicamente para realizar minhas tarefas no } \\
\text { trabalho. }\end{array}$ & 3,40 & 1,291 & 37,97 \\
\hline $\begin{array}{l}\text { Q34-O (A) meu (minha) superior procura a minha colaboração quando há } \\
\text { decisões que me afetam. }\end{array}$ & 3,03 & 1,466 & 48,38 \\
\hline $\begin{array}{l}\text { Q35-Eu costumo conversar com os (as) colegas Oficiais sobre problemas } \\
\text { relacionados ao trabalho. }\end{array}$ & 4,08 & 1,297 & 31,78 \\
\hline $\begin{array}{l}\text { Q36-Percebo que as ordens contidas nos mandados são expressas de forma } \\
\text { clara, não gerando dúvidas na sua execução. }\end{array}$ & 2,38 & 1,075 & 45,16 \\
\hline $\begin{array}{l}\text { Q37-Os mandados que recebo contém todas as informações necessárias, } \\
\text { evitando, desse modo, que eu tenha que buscar complementações junto às } \\
\text { Varas. }\end{array}$ & 2,27 & 0,979 & 43,12 \\
\hline $\begin{array}{l}\text { Q38-No meu trabalho, o (a) Juiz (a) possibilita um contato posterior caso haja } \\
\text { necessidade de algum tipo de esclarecimento acerca do teor da ordem } \\
\text { existente no mandado. }\end{array}$ & 2,49 & 1,501 & 60,28 \\
\hline
\end{tabular}

Fonte: Elaborado pelos autores com dados coletados na pesquisa de campo (2016).

O desvio-padrão (DP) indica a coesão das respostas, ou seja, quanto menor o DP mais coesas são as respostas, indicando que os respondentes concordam entre si (tem a opinião similar). Desvios padrão maiores indicam pouca coesão.

Dividindo-se o desvio-padrão (DP) pela média (M), obtém-se o coeficiente de variação $(\mathrm{CV})$, cujos limites vão de 0 a 100. Coeficiente de Variação (CV) próximo a zero indica que a maioria das importâncias atribuídas pelos respondentes foi praticamente igual. Então, quanto menor o coeficiente de variação, mais coesa é a importância atribuída. Desse modo, de acordo com a Tabela 5, as respostas das questões Q01, Q05, Q10, Q23 e Q25 apresentaram uma importância atribuída mais coesa, e as questões Q28, Q29, Q31, Q32 e Q38 apresentaram uma importância atribuída menos coesa.

A seguir passou-se para a tentativa de identificar os fatores ocupacionais que causam estresse na atividade profissional, buscando-se agrupar as diversas questões (variáveis) em fatores com a utilização da Análise Fatorial Exploratória. Nesse sentido, tem-se que a análise fatorial é "uma técnica estatística multivariada que pode sintetizar as informações de um grande número de variáveis em um número muito menor de variáveis ou fatores. Identificando relações latentes (não facilmente identificáveis) e combinando variáveis em alguns fatores, a análise fatorial simplifica a nossa compreensão dos dados [...] (HAIR JUNIOR et al., 2005, p. 388).

"[...] O teste de Kaiser-Meyer-Olklin (KMO) varia entre 0 e 1. Quanto mais perto de 
1, tanto melhor [...] (FIGUEIREDO FILHO; SILVA JUNIOR, 2010). Nesse sentido, o resultado do teste $\mathrm{KMO}(0,889)$ indica que é viável a realização da AFE, sendo que a análise do resultado da mesma indica que existem seis fatores que agrupam as 38 variáveis deste estudo. A variância explicada é da ordem de 65,81\%. Durante a realização das análises percebeu-se que a variável Q23 (Os endereços incompletos ou insuficientes, constantes nos mandados, me causam tensão excessiva) estava gerando resultados inconsistentes, tanto que em análises posteriores (Alfa de Cronbach) a mesma era indicada como uma possibilidade de exclusão. Desta forma a mesma foi retirada das análises.

Em relação à confiabilidade, "Geralmente afirma-se que um valor de 0,7-0,8 é aceitável para o $\alpha$ de Cronbach e valores substancialmente mais baixos indicam uma escala não confiável [...]" (FIELD, 2009, p. 594)

As Tabelas 6 a 11 apresentam a composição de cada um destes fatores, bem como os valores referentes a média, ao desvio-padrão e a carga fatorial, além do resultado da verificação da confiabilidade, ou consistência interna, da escala.

Tabela 6 - Fator sobrecarga de trabalho

\begin{tabular}{|c|c|c|c|}
\hline VARIÁVEIS & Média & \begin{tabular}{|l|} 
Desvio \\
Padrão \\
\end{tabular} & $\begin{array}{c}\text { Carga } \\
\text { Fatorial } \\
\end{array}$ \\
\hline $\begin{array}{l}\text { Q15-As minhas atividades, na organização em que trabalho, geram uma } \\
\text { excessiva carga de trabalho, o que, de certa forma, está ultrapassando os } \\
\text { meus limites e gerando significativa fonte de tensão em mim. }\end{array}$ & 3,63 & 1,307 & 0,898 \\
\hline $\begin{array}{l}\text { Q16-Conheço o que é qualidade de vida no trabalho, bem como sua } \\
\text { importância, mas não tenho tempo de praticar esses conceitos devido à } \\
\text { absorção pelo trabalho. }\end{array}$ & 3,57 & 1,276 & 0,863 \\
\hline $\begin{array}{l}\text { Q06-A organização em que trabalho estabelece metas de trabalho em } \\
\text { excesso, gerando grande desgaste na sua execução, acompanhamento e } \\
\text { avaliação. }\end{array}$ & 3,63 & 1,244 & 0,840 \\
\hline $\begin{array}{l}\text { Q18-Vivencio conflitos por estar em sobrecarga mas não ter como } \\
\text { questioná-la. }\end{array}$ & 3,36 & 1,408 & 0,837 \\
\hline $\begin{array}{l}\text { Q14-Muitos prazos, e prazos apertados, são rotina no meu trabalho, } \\
\text { acarretando-me grande incômodo e tensão excessiva. }\end{array}$ & 3,98 & 1,250 & 0,808 \\
\hline $\begin{array}{l}\text { Q04-Percebo que a gestão da organização em que trabalho é } \\
\text { excessivamente pautada em resultados quantitativos (números) causando- } \\
\text { me tensão excessiva. }\end{array}$ & 3,92 & 1,261 & 0,800 \\
\hline $\begin{array}{l}\text { Q05-É normal que as organizações queiram fazer mais com o mínimo, } \\
\text { porém, na organização em que atuo esta situação é exagerada, e o número } \\
\text { de Oficiais de Justiça que compõe o seu quadro funcional está muito } \\
\text { abaixo do necessário. }\end{array}$ & 4,14 & 1,157 & 0,748 \\
\hline $\begin{array}{l}\text { Q26-Sinto que a dificuldade de realizar o meu trabalho aumentou nos } \\
\text { últimos } 05 \text { anos. }\end{array}$ & 4,06 & 1,207 & 0,733 \\
\hline $\begin{array}{l}\text { Q03-O trabalho que executo consiste na realização de várias atividades ao } \\
\text { mesmo tempo, com alto grau de cobrança, o que gera em mim tensão em } \\
\text { excesso. }\end{array}$ & 3,91 & 1,190 & 0,731 \\
\hline $\begin{array}{l}\text { Q01-Executo um trabalho complexo, que me deixa desgastado (a) /muito } \\
\text { cansado (a). }\end{array}$ & 4,22 & 0,952 & 0,688 \\
\hline $\begin{array}{l}\text { Q08-No desenvolvimento do meu trabalho, sofro pressão excessiva em } \\
\text { seus diversos aspectos. }\end{array}$ & 3,63 & 1,316 & 0,685 \\
\hline Q17-Tenho dificuldade de compatibilizar os compromissos de trabalho & 3,13 & 1,388 & 0,651 \\
\hline
\end{tabular}




\begin{tabular}{l|c|c|c}
\hline com os compromissos de família, sociais, entre outros. & & \\
\hline $\begin{array}{l}\text { Q25-Sinto que a quantidade de trabalho a ser executado aumentou nos } \\
\text { últimos 05 anos. }\end{array}$ & 4,42 & 1,003 & 0,644 \\
$\begin{array}{l}\text { Q07-Grande parte das decisões relacionadas ao meu trabalho é tomada sem } \\
\text { a minha participação, o que causa em mim desgaste excessivo. }\end{array}$ & 3,72 & 1,339 & 0,586 \\
\hline $\begin{array}{l}\text { Q02-A tecnologia do meu trabalho tem me sobrecarregado muito (ex: } \\
\text { mensagens eletrônicas, softwares, sistemas integrados, etc.). }\end{array}$ & 3,51 & 1,286 & 0,562 \\
\hline $\begin{array}{l}\text { Q27-Percebo que há competitividade entre os meus colegas de trabalho. } \\
\text { Q10-O risco de violência/agressão decorrentes da minha atividade causa } \\
\text { em mim uma tensão excessiva. }\end{array}$ & 2,55 & 1,405 & 0,518 \\
\hline $\begin{array}{l}\text { Média do fator } \\
\text { Alfa de Cronbach do fator }\end{array}$ & 1,125 & 0,477 \\
\hline
\end{tabular}

Fonte: Elaborado pelos autores com dados coletados na pesquisa de campo (2016).

A partir das características das variáveis foi possível sugerir um nome para o fator, conforme indicado no título da Tabela. O resultado do Alfa de Cronbach indica a confiabilidade ou consistência interna da escala, uma vez que seu valor foi superior a 0,8 .

As variáveis que apresentaram maiores valores em relação à média foram Q05 $(4,14)$, Q26 (4,06), Q01 (4,22), Q25 $(4,42)$ e Q10 (4,10). A variável Q05 indica que, na opinião dos respondentes, o número de Oficiais de Justiça que compõe o quadro funcional da organização em que atuam está muito abaixo do necessário. Nesse sentido, Merlo et al. (2012) identificou que as futuras aposentadorias e o aumento da carga de trabalho são situações que geram preocupações para esses profissionais, uma vez que não há previsão de reposição desses trabalhadores, acarretando um aumento da carga de trabalho.

Nessa perspectiva, as variáveis Q25 e Q26 indicam uma concordância dos respondentes acerca da elevação do volume de trabalho e aumento da dificuldade de realização do trabalho nos últimos 05 anos. No estudo de Merlo et al. (2012) também foi identificado que os participantes percebiam um aumento da quantidade de trabalho $(89,2 \%) \mathrm{e}$ uma maior dificuldade para realizar o trabalho (97\%), e que essa elevação da dificuldade de realização do serviço estaria relacionada a aspectos diretamente ligados à organização do trabalho (aumento do número de processos, redução do número de servidores) e também a outros aspectos, tais como violência urbana, trânsito congestionado, dentre outros.

As variáveis que apresentaram menores valores em relação à média foram Q27, Q17 e Q18. Essas variáveis estavam relacionadas à competitividade entre os colegas de trabalho, dificuldade de compatibilizar os compromissos de trabalho com outros compromissos e sentimento de conflitos por estar em sobrecarga, mas não ter como questioná-la.

O desvio-padrão indica a coesão das respostas, ou seja, quanto menor o DP mais coesas são as respostas, indicando que os respondentes concordam entre si (tem a opinião similar). Desvios padrão maiores indicam pouca coesão. Desse modo, verifica-se na Tabela 7 
que a variável Q01 [executo um trabalho complexo, que me deixa desgastado(a)/muito cansado(a)] foi aquela que apresentou o menor valor de DP, sendo, portanto, a que apresentou maior coesão.

Tabela 7 - Fator reconhecimento profissional

\begin{tabular}{|c|c|c|c|}
\hline VARIÁ VEIS & Média & $\begin{array}{l}\text { Desvio } \\
\text { Padrão }\end{array}$ & $\begin{array}{c}\text { Carga } \\
\text { Fatorial }\end{array}$ \\
\hline $\begin{array}{l}\text { Q28-A maioria dos Diretores de Vara procura a minha colaboração } \\
\text { quando existem decisões que influem no cumprimento do mandado. }\end{array}$ & 2,02 & 1,398 & 0,861 \\
\hline $\begin{array}{l}\text { Q31-O (A) Juiz (a) conversa comigo, previamente, sobre o teor da } \\
\text { ordem existente no mandado. }\end{array}$ & 1,36 & 0,985 & 0,789 \\
\hline $\begin{array}{l}\text { Q29-A maioria dos Diretores de Vara explica o motivo das ordens e das } \\
\text { decisões importantes. }\end{array}$ & 1,82 & 1,246 & 0,757 \\
\hline $\begin{array}{l}\text { Q38-No meu trabalho, o (a) Juiz(a) possibilita um contato posterior caso } \\
\text { haja necessidade de algum tipo de esclarecimento acerca do teor da } \\
\text { ordem existente no mandado. }\end{array}$ & 2,49 & 1,501 & 0,631 \\
\hline $\begin{array}{l}\text { Q32-Os bons resultados alcançados por mim em meu trabalho são } \\
\text { reconhecidos pela organização em que trabalho. }\end{array}$ & 2,05 & 1,249 & 0,569 \\
\hline Q30-Eu me sinto respeitado pela maioria dos Diretores de Vara. & 2,73 & 1,444 & 0,568 \\
\hline Média do fator & \multicolumn{3}{|c|}{2,08} \\
\hline Alfa de Cronbach do fator & \multicolumn{3}{|c|}{0,850} \\
\hline
\end{tabular}

Fonte: Elaborado pelos autores com dados coletados na pesquisa de campo (2016).

A partir das características das variáveis foi possível sugerir um nome para o fator, conforme indicado no título da Tabela. O resultado do Alfa de Cronbach indica a confiabilidade ou consistência interna da escala, uma vez que seu valor foi superior a 0,8 . Também no estudo desenvolvido por Merlo et al. (2012), a falta de reconhecimento foi uma das questões apontadas pelos Oficiais de Justiça, tendo, de acordo com eles, a falta de respaldo e a desautorização para a realização do trabalho como consequências. Ainda, segundo o referido autor, se não são reconhecidos, há uma dificuldade de a organização entender as dificuldades inerentes à função. Nas palavras do autor, "O reconhecimento no trabalho é indispensável para a construção do equilíbrio psíquico e isso não vem ocorrendo de forma adequada. Esse reconhecimento não se dá, inicialmente, sobre a pessoa do trabalhador, mas sobre o próprio trabalho" (MERLO et al., 2012, p. 107).

Como o respondente poderia atribuir um valor que variava em uma escala de 1 até 5 , em que "1" representava discordo totalmente e "5" concordo totalmente, e a média do Fator reconhecimento profissional foi 2,08, pode-se concluir que, dentre os respondentes, não há uma elevada sensação de reconhecimento profissional. A variável Q31 foi a que apresentou menor média e menor desvio padrão (indicando que os respondentes concordam entre si), e a variável Q30 foi a que apresentou maior média. 
Tabela 8 - Fator ameaça/agressão/violência

\begin{tabular}{l|c|c|c}
\hline \multicolumn{1}{c|}{ VARIÁVEIS } & Média & $\begin{array}{c}\text { Desvio } \\
\text { Padrão }\end{array}$ & $\begin{array}{c}\text { Carga } \\
\text { Fatorial }\end{array}$ \\
\hline $\begin{array}{l}\text { Q12-Há situações de desrespeito humano na organização em que } \\
\text { trabalho. }\end{array}$ & 2,59 & 1,419 & 0,713 \\
$\begin{array}{l}\text { Q11-Na organização em que trabalho existe a prática recorrente de } \\
\text { isolar/perseguir pessoas que eventualmente sejam consideradas } \\
\text { funcionalmente inadequadas (assédio moral). }\end{array}$ & 2,53 & 1,438 & 0,707 \\
$\begin{array}{l}\text { Q19-Convivo com situações de tensão excessiva inerente às relações } \\
\text { humanas no trabalho. }\end{array}$ & 3,31 & 1,496 & 0,598 \\
\hline $\begin{array}{l}\text { Q09-A convivência com ocorrências de alto impacto emocional, deixa- } \\
\text { me tenso (a) no trabalho. }\end{array}$ & 4,16 & 1,103 & 0,596 \\
$\begin{array}{l}\text { Q13-Para atingir os resultados que a organização exige, muitas vezes, } \\
\text { defronto-me com situações em que há orientações superiores, explícitas }\end{array}$ & 2,44 & 1,405 & 0,565 \\
\hline $\begin{array}{l}\text { ou implícitas, para agir fora do que considero eticamente correto. } \\
\text { Média do fator }\end{array}$ & $\mathbf{3 , 0 1}$ \\
\hline Alfa de Cronbach do fator & \multicolumn{3}{|c}{0,860} \\
\hline Fonte: Elaborado pelos autores
\end{tabular}

Fonte: Elaborado pelos autores com dados coletados na pesquisa de campo (2016).

A partir das características das variáveis foi possível sugerir um nome para o fator, conforme indicado no título da Tabela. O resultado do Alfa de Cronbach indicam a confiabilidade ou consistência interna da escala, uma vez que foi superior a 0,8 .

A média do fator ameaça/agressão/violência foi 3,01, sendo que a variável Q13 apresentou a menor média e a variável Q09 apresentou a maior média, sugerindo que, para os pesquisados, a convivência com situações de alto impacto emocional gera uma tensão no trabalho.

Tabela 9 - Fator autorreconhecimento

\begin{tabular}{|c|c|c|c|}
\hline VARIÁ VEIS & Média & $\begin{array}{l}\text { Desvio } \\
\text { Padrão }\end{array}$ & $\begin{array}{c}\text { Carga } \\
\text { Fatorial }\end{array}$ \\
\hline $\begin{array}{l}\text { Q33-Eu me sinto seguro(a) tecnicamente para realizar minhas tarefas no } \\
\text { trabalho. }\end{array}$ & 3,40 & 1,291 & 0,730 \\
\hline $\begin{array}{l}\text { Q34-O (A) meu (minha) superior procura a minha colaboração quando } \\
\text { há decisões que me afetam. }\end{array}$ & 3,03 & 1,466 & 0,695 \\
\hline $\begin{array}{l}\text { Q20-Na organização em que trabalho, há um canal aberto de } \\
\text { comunicação para discussão das situações de dificuldade e tensão } \\
\text { vivenciadas. }\end{array}$ & 2,38 & 1,280 & 0,522 \\
\hline Média do fator & \multicolumn{3}{|c|}{2,94} \\
\hline Alfa de Cronbach do fator & \multicolumn{3}{|c|}{0,658} \\
\hline
\end{tabular}

Fonte: Elaborado pelos autores com dados coletados na pesquisa de campo (2016).

A partir das características das variáveis foi possível sugerir um nome para o fator, conforme indicado no título da Tabela. O resultado do Alfa de Cronbach indica a confiabilidade ou consistência interna da escala. A variável que apresentou menor média e menor desvio padrão foi a variável Q20, indicando que os respondentes concordam entre si, e que não há uma grande percepção acerca da existência de um canal aberto de comunicação 
para discussão das situações de dificuldade e tensão vivenciadas. A variável que apresentou a maior média foi Q33, sugerindo que os respondentes se consideram tecnicamente seguros na realização das tarefas relacionadas ao trabalho.

Tabela 10 - Fator clareza de informações

\begin{tabular}{|c|c|c|c|}
\hline VARIÁVEIS & Média & $\begin{array}{c}\text { Desvio } \\
\text { Padrão }\end{array}$ & $\begin{array}{c}\text { Carga } \\
\text { Fatorial }\end{array}$ \\
\hline $\begin{array}{l}\text { Q36-Percebo que as ordens contidas nos mandados são expressas de } \\
\text { forma clara, não gerando dúvidas na sua execução. }\end{array}$ & 2,38 & 1,075 & 0,777 \\
\hline $\begin{array}{l}\text { Q37-Os mandados que recebo contém todas as informações necessárias, } \\
\text { evitando, desse modo, que eu tenha que buscar complementações junto } \\
\text { às Varas. }\end{array}$ & 2,27 & 0,979 & 0,751 \\
\hline Média do fator & \multicolumn{3}{|c|}{2,32} \\
\hline Alfa de Cronbach do fator & \multicolumn{3}{|c|}{0,722} \\
\hline
\end{tabular}

Fonte: Elaborado pelos autores com dados coletados na pesquisa de campo (2016).

A partir das características das variáveis foi possível sugerir um nome para o fator, conforme indicado no título da Tabela. O resultado do Alfa de Cronbach indica a confiabilidade ou consistência interna da escala. A média do fator clareza de informação foi 2,32, sugerindo que, para os respondentes, a clareza de informações dentro da organização poderia ser melhorada. Em relação à comunicação, o estudo de Merlo et al. (2012) identificou que os Oficiais de Justiça muitas vezes necessitavam repetir um mesmo procedimento em razão dos erros constantes nos mandados, e, mesmo constatando o erro existente, não tinham possibilidade de corrigi-lo, sendo que, em algumas ocasiões, eram orientados a cumprir o mandado mesmo sabendo do erro. No referido estudo, também foi identificada a falta de comunicação entre a Vara e a Central de Mandados. Ainda segundo Merlo et al. (2012, p.107), "[..] praticamente não ocorrem contatos diretos com os juízes e eles se sentem sem possibilidades de construir referências sobre a qualidade de seu trabalho e sem condições de buscar amparo para as situações inesperadas que ocorrem em seu dia a dia."

Desse modo, percebe-se, tanto neste estudo quanto no de Merlo et al. (2012), que a falta de clareza e insuficiência de informações permeiam a atividade dos Oficiais de Justiça pesquisados, podendo gerar estresse nesses trabalhadores.

Assim, corrobora-se a perspectiva de que algumas das dificuldades encontradas por esses profissionais são os endereços imprecisos, as situações imprevistas (aquelas que fogem das situações comuns no exercício da função), a falta de interação entre os magistrados e os oficiais de justiça, além dos mandados sem total clareza ou distribuídos de forma incompleta (PIMENTEL, 2014). 
Tabela 11 - Fator outros

\begin{tabular}{|c|c|c|c|}
\hline VARIÁVEIS & Média & $\begin{array}{c}\text { Desvio } \\
\text { Padrão }\end{array}$ & $\begin{array}{c}\text { Carga } \\
\text { Fatorial }\end{array}$ \\
\hline $\begin{array}{l}\text { Q21-Percebo que na organização em que atuo há uma colaboração dos } \\
\text { colegas de trabalho na execução das tarefas desempenhadas. }\end{array}$ & 3,40 & 1,291 & 0,678 \\
\hline $\begin{array}{l}\text { Q35-Eu costumo conversar com os (as) colegas Oficiais sobre problemas } \\
\text { relacionados ao trabalho. }\end{array}$ & 4,08 & 1,297 & 0,626 \\
\hline Q22-O trânsito me deixa tensionado excessivamente. & 3,88 & 1,230 & 0,566 \\
\hline Média do fator & \multicolumn{3}{|c|}{3,78} \\
\hline Alfa de Cronbach do fator & \multicolumn{3}{|c|}{0,480} \\
\hline
\end{tabular}

Fonte: Elaborado pelos autores com dados coletados na pesquisa de campo (2016).

A partir das características das variáveis foi possível sugerir um nome para o fator, conforme indicado no título da Tabela, porém, neste caso, as três variáveis possuem características bastante distintas, então optou-se pelo título de outros. O resultado do Alfa de Cronbach $(0,480)$ foi muito abaixo do recomendado, e o mesmo não apresenta indicação de que a exclusão de algumas das variáveis venha a melhorar o resultado. Desta forma, este fator será desconsiderado nas análises subsequentes.

A Tabela 12 resume os fatores identificados

Tabela 12 - Resumo dos fatores

\begin{tabular}{l|c}
\hline \multicolumn{1}{c|}{ Fatores } & Média \\
\hline Fator sobrecarga de trabalho & 3,73 \\
\hline Fator reconhecimento profissional & 2,08 \\
\hline Fator ameaça/agressão/violência & 3,01 \\
\hline Fator autorreconhecimento & 2,94 \\
\hline Fator clareza de informação & 2,32 \\
\hline
\end{tabular}

Fonte: Elaborado pelos autores com dados coletados na pesquisa de campo (2016).

Estes fatores indicam os fatores ocupacionais que causam estresse na atividade profissional. O fator sobrecarga de trabalho apresentou a média mais elevada em relação aos demais e pode ser indicado como o principal fator relacionado ao estresse ocupacional. Por outro lado, o fator reconhecimento profissional foi o que apresentou a menor média em relação aos demais.

Nesse sentido, Merlo et al. (2012, p.107) explana que “[...] a execução de um mandado pode demorar horas, ou mesmo dias, e coloca os oficiais em situações embaraçosas, perigosas e, muitas vezes, insalubres, não sendo computada essa qualidade do trabalho, apenas o número de mandados efetuados."

O segundo fator com média mais elevada é o relacionado à ameaça, agressão e/ou violência, sendo que a média deste fator está localizado no meio termo entre a discordância e a concordância total (ponto neutro, nem concordo, nem discordo), indicando que no geral este 
fator não tem um impacto significativo na geração de estresse junto aos Oficiais de Justiça Avaliadores Federais que participaram deste estudo.

O fator denominado autorreconhecimento apresentou uma média também próxima ao ponto neutro da escala, o que também indica que este fator não é um dos que gera estresse.

O fator reconhecimento profissional apresenta médias baixa, o que é um problema porque os respondentes indicaram em média que discordam parcialmente das afirmativas que indicam o reconhecimento, e isto pode gerar estresse. O mesmo ocorre com o fator clareza de informação, sendo este um motivador do retrabalho, gerando maior carga de trabalho e, consequentemente, aumentando o estresse.

Com relação ao primeiro objetivo específico, buscou-se verificar por meio do teste para diferença de médias entre grupos, se existe diferença nas médias dos cinco fatores identificados pela AFE.

Tabela 13 - Fatores X Sexo

\begin{tabular}{|c|c|c|c|c|c|}
\hline & Sexo & Média & $\begin{array}{l}\text { Desvio } \\
\text { Padrão }\end{array}$ & Teste $\mathbf{T}$ & Sig \\
\hline \multirow{2}{*}{ Sobrecarga } & Masculino & 3,69 & 0,917 & \multirow{2}{*}{$-0,463$} & \multirow{2}{*}{0,645} \\
\hline & Feminino & 3,79 & 0,988 & & \\
\hline \multirow{2}{*}{ Reconhecimento } & Masculino & 2,14 & 1,027 & \multirow{2}{*}{0,763} & \multirow{2}{*}{0,448} \\
\hline & Feminino & 1,98 & 0,946 & & \\
\hline \multirow{2}{*}{ Ameaça } & Masculino & 2,95 & 1,137 & \multirow{2}{*}{$-0,626$} & \multirow{2}{*}{0,533} \\
\hline & Feminino & 3,10 & 1,060 & & \\
\hline \multirow{2}{*}{ Autorreconhecimento } & Masculino & 2,98 & 0,964 & \multirow{2}{*}{0,520} & \multirow{2}{*}{0,605} \\
\hline & Feminino & 2,86 & 1,161 & & \\
\hline \multirow{2}{*}{ Informação } & Masculino & 2,43 & 0,908 & \multirow{2}{*}{1,332} & \multirow{2}{*}{0,186} \\
\hline & Feminino & 2,16 & 0,902 & & \\
\hline
\end{tabular}

Fonte: Elaborado pelos autores com dados coletados na pesquisa de campo (2016).

Nesse sentido, conforme pode ser observado na Tabela 13, os resultados indicam que não existe diferença em nenhum dos fatores em função do sexo, não corroborando o estudo de Stefano, Bonanato e Raifur (2013).

Com relação ao local de lotação, verifica-se que a sobrecarga de trabalho e o reconhecimento são fatores nos quais existe diferença entre os grupos a partir da lotação. Os resultados indicam a existência de diferença entre os lotados na capital e os lotados no interior, com medias superiores, no caso da sobrecarga de trabalho, para os lotados na capital e com média superiores, no caso do reconhecimento profissional, para os lotados no interior. 
Tabela 14 - Fatores X Localidade de lotação

\begin{tabular}{|c|c|c|c|c|c|}
\hline Fator & Lotação & Média & Desvio Padrão & $\mathbf{F}$ & Sig \\
\hline \multirow{4}{*}{ Sobrecarga } & Capital & 4,07 & 0,680 & \multirow{4}{*}{5,457} & \multirow{4}{*}{0,006} \\
\hline & $\begin{array}{c}\text { Região } \\
\text { Metropolitana }\end{array}$ & 3,85 & 1,167 & & \\
\hline & Interior & 3,42 & 1,014 & & \\
\hline & Total & 3,73 & 0,940 & & \\
\hline \multirow{4}{*}{ Reconhecimento } & Capital & 1,67 & 0,714 & \multirow{4}{*}{8,305} & \multirow{4}{*}{0,001} \\
\hline & $\begin{array}{c}\text { Região } \\
\text { Metropolitana }\end{array}$ & 1,72 & 0,672 & & \\
\hline & Interior & 2,48 & 1,088 & & \\
\hline & Total & 2,08 & 0,995 & & \\
\hline \multirow{4}{*}{ Ameaça } & Capital & 3,17 & 1,088 & \multirow{4}{*}{1,757} & \multirow{4}{*}{0,179} \\
\hline & $\begin{array}{c}\text { Região } \\
\text { Metropolitana }\end{array}$ & 3,47 & 1,366 & & \\
\hline & Interior & 2,80 & 1,064 & & \\
\hline & Total & 3,01 & 1,104 & & \\
\hline \multirow{4}{*}{ Autorreconhecimento } & Capital & 2,98 & 1,019 & \multirow{4}{*}{0,141} & \multirow{4}{*}{0,868} \\
\hline & $\begin{array}{c}\text { Região } \\
\text { Metropolitana }\end{array}$ & 3,06 & 1,042 & & \\
\hline & Interior & 2,88 & 1,076 & & \\
\hline & Total & 2,94 & 1,039 & & \\
\hline \multirow{4}{*}{ Informação } & Capital & 2,26 & 0,898 & \multirow{4}{*}{0,995} & \multirow{4}{*}{0,374} \\
\hline & $\begin{array}{c}\text { Região } \\
\text { Metropolitana }\end{array}$ & 1,92 & 0,861 & & \\
\hline & Interior & 2,43 & 0,925 & & \\
\hline & Total & 2,32 & 0,910 & & \\
\hline
\end{tabular}

Fonte: Elaborado pelos autores com dados coletados na pesquisa de campo (2016).

Nesse sentido, afirma-se que, assim como, frequentemente, a incidência de determinadas doenças não ocorre de maneira uniforme na população, ou seja, identificam-se variações conforme o país, a região, a idade, o gênero, a classe social, a inserção da pessoa no ambiente rural ou urbano (LEVINE; SCOTCH, 1970) e a posição do indivíduo na estrutura social (FARO; PEREIRA, 2011), neste estudo, o fator estressor apresentou variação conforme a localidade de lotação do indivíduo, porém não se verificou diferença, em nenhum dos fatores, em função do gênero. 


\section{CONSIDERAÇÕES FINAIS}

Esta pesquisa teve como população de estudo os Oficiais de Justiça Avaliadores Federais associados à Assojaf MG ou Assojaf PR. Desse modo, identificou-se que a maioria da amostra pesquisada declarou-se ser do sexo masculino, ter idade entre 31 e 40 anos, atuar como Oficial de Justiça de 11 a 20 anos, possuir pós-graduação completa, não exercer outra atividade profissional, ser casado ou ter uma união estável e estar lotado no interior do Estado.

O objetivo geral foi identificar os fatores ocupacionais que causam estresse na atividade profissional da referida população. Neste estudo, foram identificados como fatores ocupacionais que causam estresse na atividade profissional o fator sobrecarga de trabalho, o fator reconhecimento profissional, o fator ameaça/agressão/violência, o fator auto reconhecimento e o fator clareza de informação. Nesse sentido, identificou-se que o fator sobrecarga de trabalho apresentou a média mais elevada em relação aos demais e pode ser indicado como o principal fator relacionado ao estresse ocupacional na população estudada.

Em relação aos objetivos específicos, buscou-se: a) Investigar se há uma diferença estatística significativa entre os gêneros e ao local de lotação (capital e interior) dos Oficiais de Justiça Avaliadores Federais no tocante aos fatores geradores de estresse na atividade profissional; b) Identificar se eles sofrem agressões/violência (verbais e físicas) no exercício da sua atividade profissional e sua relação com o estresse; c) Identificar se há uma sobrecarga de trabalho no exercício da função dos Oficiais de Justiça avaliadores Federais.

Respondendo aos objetivos específicos, não se verificou diferença, em nenhum dos fatores, em função do gênero. Com relação ao local de lotação, verificou-se que a sobrecarga de trabalho e o reconhecimento são fatores nos quais existe diferença entre os grupos a partir da lotação. Os resultados indicam a existência de diferença entre os lotados na capital e os lotados no interior, com medias superiores, no caso da sobrecarga de trabalho, para os lotados na capital e com médias superiores, no caso do reconhecimento profissional, para os lotados no interior. Identificou-se, ainda, que 5,7\% dos respondentes afirmou não ter sofrido nenhum tipo de ameaça/violência/agressão verbal ou física no exercício da atividade profissional, enquanto que $73,9 \%$ da amostra afirmou já ter sofrido ameaça/violência/agressão verbal no exercício da função. Por fim, verificou-se que o fator sobrecarga de trabalho apresentou a média mais elevada em relação aos demais e pode ser indicado como o principal fator relacionado ao estresse ocupacional na população estudada.

Nesse sentido, afirma-se que a identificação dos fatores estressores se torna relevante a fim de se efetuar as implementações organizacionais necessárias à prevenção e diminuição 
do estresse entre os profissionais (FINNEY et al., 2013), uma vez que os estressores ocupacionais impactam na qualidade de vida do trabalhador, afetando diretamente a sua saúde e seu bem-estar (GOULART JUNIOR et al., 2014).

Observou-se, uma predominância do gênero masculino na amostra pesquisada, sendo que essa situação também foi identificada na pesquisa de Merlo et al. (2012) com Oficiais de Justiça no Rio Grande do Sul. Também verificou-se que mais de 95\% dos participantes da pesquisa afirmaram não exercer outra atividade profissional além da desenvolvida no Poder Judiciário Federal. Desse modo, outros estudos tendo como população os Oficiais de Justiça Avaliadores Federais contribuiriam no sentido de se identificar se a predominância do sexo masculino e a dedicação exclusiva ao serviço público seria uma característica dessa profissão.

Identifica-se, tanto neste estudo quanto no de Merlo et al. (2012), que a falta de clareza e insuficiência de informações permeiam a atividade dos Oficiais de Justiça pesquisados, podendo gerar estresse nesses trabalhadores. Assim, corrobora-se a perspectiva de que algumas das dificuldades encontradas por esses profissionais são os endereços imprecisos, as situações imprevistas (aquelas que fogem das situações comuns no exercício da função), a falta de interação entre os magistrados e os oficiais de justiça, além dos mandados sem total clareza ou distribuídos de forma incompleta (PIMENTEL, 2014).

Nesse sentido, a criação/melhoria de canais de comunicação poderia contribuir tanto para a redução dos fatores estressores desta profissão e, consequentemente o aumento da qualidade de vida destes servidores, quanto para o aumento da eficiência, uma vez que poderia haver a redução do retrabalho e de atividades desnecessárias.

Outro aspecto que merece atenção é o treinamento inicial destes profissionais. Dentre os respondentes, $35,2 \%$ afirmaram ter recebido treinamento para realizar as tarefas enquanto $64,8 \%$ informaram o oposto. Nesse sentido, um estudo que objetivava identificar os efeitos do trabalho sobre a saúde de Oficiais da Justiça Federal de Porto Alegre identificou que um dos fatores de sofrimento apontado por eles foi a ausência de treinamento inicial para a execução da atividade (MERLO et al., 2012). Desse modo, a implementação de treinamento inicial desses profissionais poderia contribuir no aumento da qualidade de vida no trabalho desses trabalhadores.

Desse modo, levando-se em consideração que os fatores ocupacionais que causam estresse na atividade profissional são o fator sobrecarga de trabalho, o fator reconhecimento profissional, o fator ameaça/agressão/violência, o fator autorreconhecimento e o fator clareza de informação, sugere-se como práticas para a QVT e gestão de pessoas dos Oficiais de Justiça a implementação/melhoria dos canais de comunicação de modo que possa haver uma 
maior interação desses servidores com a organização, possibilitando que eles possam expor as dificuldades vivenciadas e sugerir melhorias nas suas rotinas de trabalho. Medidas nesse sentido poderiam reduzir o retrabalho e, consequentemente, diminuiriam a sobrecarga de trabalho, outro fator apontado por eles como gerador de estresse.

Em relação ao fator ameaça/agressão/violência, seria indicado que a organização investigada avaliasse e planejasse quais medidas poderiam ser realizadas para que esses servidores pudessem exercer sua atividade com maior segurança.

Nesse sentido, "[...] estudos sobre estresse nas organizações tornam-se cada vez mais relevantes, uma vez que gestores podem utilizá-los para a definição de políticas e estratégias de redução do estresse organizacional e suas consequências. [...] (STEFANO; BONANATO; RAIFUR, 2013, p. 89). Desse modo, estudos que investigam o estresse do trabalhador são importantes porque podem contribuir para a melhoria da qualidade de vida no trabalho e do próprio trabalhador, gerando, também, maior competitividade, produtividade e satisfação no trabalho (VISENTINI, et al., 2010).

Em relação aos programas organizacionais para lidar com o estresse, eles podem ser voltados para: a ginástica laboral; uma comunicação positiva; a maturidade de interação; a educação alimentar; o arranjo físico/ambiente; a corresponsabilidade e critérios e modelos legitimados (LIMONGI-FRANÇA; RODRIGUES, 2007).

No tocante às limitações desse estudo, cita-se o fato de ele ter abrangido apenas os Oficiais de Justiça Avaliadores Federais associados à Assojaf MG ou à Assojaf PR. Portanto, outros estudos que conseguissem abranger uma população maior poderiam trazer uma melhor compreensão acerca das situações que permeiam a atividade desses profissionais. Também seria interessante que os estudos futuros identificassem a qual Órgão do Poder Judiciário a amostra pertence (Tribunal Regional Federal, Tribunal Regional Eleitoral, Tribunal Regional do Trabalho, etc.), para uma melhor compreensão das características da amostra.

Outra limitação que pode ser apontada é que este estudo realizou apenas um levantamento dos fatores causadores de estresse ocupacional, entretanto, seria relevante que pesquisas futuras investigassem as consequências ocasionadas por estas fontes.

Por fim, sintetizando, os resultados obtidos revelaram como fatores ocupacionais que causam estresse na atividade profissional o fator sobrecarga de trabalho, o fator reconhecimento profissional, o fator ameaça/agressão/violência, o fator auto reconhecimento e o fator clareza de informação, sendo que o fator sobrecarga de trabalho apresentou a média mais elevada em relação aos demais e pode ser indicado como o principal fator relacionado ao estresse ocupacional na população estudada. Não se verificou diferença, em nenhum dos 
fatores, em função do gênero, e, com relação ao local de lotação, verificou-se que a sobrecarga de trabalho e o reconhecimento são fatores nos quais existe diferença entre os grupos a partir da lotação. 


\section{REFERÊNCIAS}

ALBUQUERQUE, L. G.; LIMONGI-FRANÇA, A. C. Estratégias de recursos humanos e gestão da qualidade de vida no trabalho: o stress e a expansão do conceito de qualidade total. Revista de Administração. São Paulo: v. 33, n. 2, p. 40-51, abr.jun. 1998. Disponível em: <http://www.rausp.usp.br/busca/artigo.asp?num_artigo=144>. Acesso em: 09/04/2015.

AMORIM, T. G. F. N. Qualidade de vida no trabalho: preocupação também para os servidores públicos?. Revista Eletrônica de Ciência Administrativa (RECADM). Campo Largo - PR. v.9, n. $1, \quad$ p. 35-48, maio/2010. Disponível em: <http://www.spell.org.br/documentos/ver/5211/qualidade-de-vida-no-trabalho--preocupacaotambem-para-servidores-publicos->. Acesso em: 07/05/2015.

ANAJUSTRA, Associação Nacional do Servidores da Justiça do Trabalho. Qualidade de vida e serviço público: presidente da ABQV fala sobre o tema. 2010. Disponível em <https://www.anajustra.org.br/noticia/4274/8/Qualidade-de-vida-e-servico-publicopresidente-da-ABQV-fala-sobre-o-tema $>$. Acesso em: 04/12/2014.

AREIAS, M. E. Q.; GUIMARÃES, L. A. M. Gênero e estresse em trabalhadores de uma universidade pública do Estado de São Paulo. Psicologia em Estudo. Maringá, v. 9, n. 2, p. 255-262, 2004. Disponível em: <http://www.scielo.br/pdf/pe/v9n2/v9n2a11.pdf>. Acesso em $10 / 06 / 2015$.

ARELLANO, E. B. Avaliação dos programas de qualidade de vida no trabalho - análise crítica das práticas das empresas premiadas no Brasil.São Paulo: 2008. 194 p. Tese Programa de Pós-Graduação Interunidades em Nutrição Humana Aplicada - PRONUT, Faculdade de Ciências Farmacêuticas, Faculdade de Economia, Administração e Contabilidade, Faculdade de Saúde Pública, Universidade de São Paulo. Disponível em: $<$ http://www.teses.usp.br/teses/disponiveis/89/89131/tde-11082008-110815/pt-br.php>.

Acesso em: 26/04/2015.

ARSHADI, N.; DAMIRI, H. The Relationship of Job Stress with Turnover Intention and Job Performance: Moderating Role of OBSE. Procedia - Social and Behavioral Sciences, v. 84, p. 707-710, 2013. Disponível em: <http://ac.els-cdn.com/S1877042813017059/1-s2.0S1877042813017059-main.pdf? tid=ca103a1a-e140-11e4-9cce00000aab0f01\&acdnat $=1428863091 \_2 b 608 a 6 a 4 d 488 b b 142829 a e a 4 f 478 b 4 e>$. Acesso em: $12 / 04 / 2015$.

ASSOJAF-GO, Associação dos Oficiais de Justiça Avaliadores Federais do Estado de Goiás. Oficial de Justiça: os riscos da profissão ganham destaque na mídia nacional. 2013. Disponível em: <http://assojafgo.org.br/noticia/2013/08/02/os-riscos-da-profissao-ganhamdestaque-na-midia-nacional/>. Acesso em: 07/04/2015. 
ASSOJAF-GO, Associação dos Oficiais de Justiça Avaliadores Federais do Estado de Goiás. Pesquisa aponta que 50\% dos oficiais de Justiça federais do RS sofrem de distúrbios psiquiátricos. 2013 b. Disponível em: <http://assojafgo.org.br/noticia/2013/09/11/pesquisaaponta-que-50-dos-oficiais-de-justica-federais-do-rs-sofrem-de-disturbios-psiquiatricos/> . Acesso em: 07/04/2015.

ASSOJAF-GO, Associação dos Oficiais de Justiça Avaliadores Federais de Goiás. Crimes cometidos contra Oficiais de Justiça durante o cumprimento de ordens judiciais. 2015. Disponível em: <http://assojafgo.org.br/wp-content/uploads/2015/03/relatorio-crimes-contraoficiais-justica-mar2015.pdf >. Acesso em: 07/04/2015.

BAHRI YUSOFF, M. S. Dealing with Occupational Stress - A Self-Changed Model. Occupational Medicine e Health Affairs. V. 1, n. 7, 2013. Disponível em: $<$ http://esciencecentral.org/journals/dealing-with-occupational-stress-a-selfchanged-model2329-6879.1000138.php?aid=20917 > . Acesso em: 28/04/2015.

BERRY, L. L.; MIRABITO, A. M.; BAUN, W. B. What's the hard return on employee welness programs?. Harvard Business Review. December, v. 88, n. 12, p. 104-112, 2010.

CANOVA, K. R.; PORTO, J. B. O Impacto dos Valores Organizacionais no Estresse Ocupacional: Um Estudo com Professores de Ensino Médio. Revista de Administração Mackenzie, v. 11, n. 5, art. 169, p. 4-31, 2010. Disponível em: <http://www.spell.org.br/documentos/ver/4229/o-impacto-dos-valores-organizacionais-noestresse-ocupacional--um-estudo-com-professores-de-ensino-medio >. Acesso em: 27/04/2015.

CNJ - Conselho Nacional de Justiça. Diretriz Estratégica para 2015. 2015. Disponível em: $<\quad$ http://www.cnj.jus.br/images/gestao-planejamentocnj/2015/Diretriz_estrat\%C3\%A9gica_aprovada_no_VIII_Encontro.pdf >. Acesso em 19/07/2015.

COOPER, C. L. Medios de afrontar el estrés en las organizaciones: la función del personal directivo . In R. Kalimo, M. El-Batawi e C. L. Cooper, Los factores psicosociales en el trabajo y su relación con la salud, Parte V, Capítulo 17 (pp. 183-203). Genebra: Organizacion Mundia de la $\quad$ Salud $\quad-\quad$ OMS, $1988 . \quad$ Disponível em: $<$ http://whqlibdoc.who.int/publications/1988/9243561022_spa_Part5-6.pdf $>$. Acesso em: 04/06/2015.

COOPER, C. L.; DAVIDSON, M. Las fuentes de estrés em el trabajo y su relación con los ambientes no laborales. In R. Kalimo, M. El-Batawi e C. L. Cooper, Los factores psicosociales en el trabajo y su relación con la salud, Parte III, Capítulo 10 (pp. 97-109). Genebra: Organizacion Mundia de la Salud - OMS, 1988. Disponível em: $<$ http://whqlibdoc.who.int/publications/1988/9243561022_spa_Part3-4.pdf $>$. Acesso em: 
04/06/2015.

COOPER, D. R.; SCHINDLER, P. S. Métodos de pesquisa em administração. Trad. Iuri Duquia Abreu. 10 edição. Porto Alegre: Bookman, 2011.

CSJT, Conselho Superior da Justiça do Trabalho. Resolução CSJT nº 145/2014. Disponível em:

<http://aplicacao.tst.jus.br/dspace/bitstream/handle/1939/53283/2014_res0145_csjt.pdf?seque nce $=1>$. Acesso em: 18/04/2015.

FARO, A.; PEREIRA, M. E. Raça, racismo e saúde: a desigualdade social da distribuição do estresse. Estudos de Psicologia. v. 16, n. 3, set./dez., p. 271-278, 2011. Disponível em: <http://www.scielo.br/pdf/epsic/v16n3/09.pdf>. Acesso em 10/06/2015.

FAVA, L. R. Absenteísmo e Presenteísmo. O gerente.com. Carreira/qualidade de vida. 2007. Disponível

$<$ http://www.ogerente.com.br/novo/colunas_ler.php?canal=6\&canallocal=53\&canalsub2=177

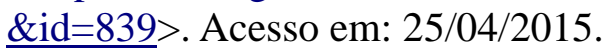

FIELD, Andy. Descobrindo a estatística usando o SPSS. $2^{\text {a }}$ edição. 688 p. Tradução: Lorí Viali. Porto Alegre: Artmed, 2009.

FIGUEIREDO FILHO, Dalson Brito; SILVA JÚNIOR, José Alexandre da. Visão além do alcance: uma introdução à análise fatorial. Opinião Pública. v. 16, n. 1, jun., p. 160-185, 2010. Disponível em: <http://www.scielo.br/pdf/op/v16n1/a07v16n1.pdf>. Acesso em 27/04/2016.

FINNEY, C.; STERGIOPOULOS, E.; HENSEL, J.; BONATO, S.; DEWA, C. S. Organizational stressors associated with job stress and burnout in correctional officers: a systematic review. BMC Public Health. 2013, 13:82. Disponível em:<http://www.ncbi.nlm.nih.gov/pmc/articles/PMC3564928/pdf/1471-2458-13-82.pdf>. Acesso em: 09/04/2015.

GMELCH, W. H. A conceptual Understanding of administrative stress. Annual meeting of the American Educational Research Association. Chigago, April, 1991. Disponível em: $<$ http://files.eric.ed.gov/fulltext/ED341148.pdf>. Acesso em 06/06/2015.

GODOY, A. S. Introdução à pesquisa qualitativa e suas possibilidades. Revista de Administração de Empresas. v. 35, n. 2, p. 57-63, mar/abr. São Paulo: 1995. Disponível em: $<$ http://rae.fgv.br/sites/rae.fgv.br/files/artigos/10.1590_S0034-75901995000200008.pdf >. Acesso em 19/07/2015. 
GOULART JUNIOR, E.; CARDOSO, H. F.; DOMINGUES, L. C.; GREEN, R. M.; LIMA, T. R. Trabalho e estresse: identificação do estresse e dos estressores ocupacionais em trabalhadores de uma unidade administrativa de uma instituição pública de ensino superior (IES). Revista Gestão Universitária na América Latina - GUAL. v. 7, n. 1, p. 01-17, Florianópolis, jan. 2014. Disponível em: <https://periodicos.ufsc.br/index.php/gual/article/viewFile/1983-4535.2014v7n1p1/26333>. Acesso em: 2/04/2015.

HAIR JUNIOR, Joseph F.; BABIN, Barry; MONEY, Arthur H.; SAMOUEL, Phillip. Fundamentos de métodos de pesquisa em administração. Tradução: Lene Belon Ribeiro. 471 p. Porto Alegre: Bookman, 2005.

KALIMO, R.. Los factores psicosociales y la salud de los trabajadores: panorama general. In R. Kalimo, M. El-Batawi e C. L. Cooper, Los factores psicosociales en el trabajo y su relación con la salud (pp. 3-8). Genebra: Organizacion Mundia de la Salud - OMS, 1988. Disponível em: $<$ http://whqlibdoc.who.int/publications/1988/9243561022_spa.pdf $>$. Acesso em: $23 / 04 / 2015$.

KALIMO R.; MEJMAN, T. Respuestas psicológicas y de conducta al estrés em el trabajo. In R. Kalimo, M. El-Batawi e C. L. Cooper, Los factores psicosociales en el trabajo y su relación con la salud (pp. 23-36). Genebra: Organizacion Mundia de la Salud - OMS, 1988. Disponível em: $<$ http://whqlibdoc.who.int/publications/1988/9243561022_spa.pdf $>$. Acesso em: 23/04/2015.

KAUARK, F. S.; MANHÃES, F. C.; MEDEIROS, C. H. Metodologia da pesquisa: um guia prático. Bahia: Via Litterarum, 2010.

LEÃO, A. L. M. S.; MELLO, S. C. B.; VIEIRA, R. S. G. O papel da teoria no método de pesquisa em Administração. Revista Organizações em Contexto, v. 5, n. 10, p. 1-16, 2009. Disponível em: < http://www.spell.org.br/documentos/ver/5935/o-papel-da-teoria-no-metodode-pesquisa-em-admi--->. Acesso em 19/07/2015.

LEVI, L. Adaptación del trabajo a las capacidades y necesidades humanas: mejoras del contenido y la organización del trabajo . In R. Kalimo, M. El-Batawi e C. L. Cooper, Los factores psicosociales en el trabajo y su relación con la salud, Parte V, Capítulo 16 (pp. 166182). Genebra: Organizacion Mundia de la Salud - OMS, 1988. Disponível em: $<$ http://whqlibdoc.who.int/publications/1988/9243561022_spa_Part5-6.pdf $>$. Acesso em: 04/06/2015.

LEVINE, S.; SCOTCH, N. A. Social stress (1970). In: Social Stress. Editors Levine S. e Scotch N. A., Part I, Transaction Pub. 295 p., 2013. Disponível em: < https://books.google.com.br/books?hl=pt-

$\mathrm{BR} \& \mathrm{lr}=\& \mathrm{id}=\mathrm{Zd} 1 \mathrm{tAAAAQBAJ} \& \mathrm{i}=\mathrm{fnd} \& \mathrm{pg}=\mathrm{PP} 1 \& \mathrm{dq}=$ social+stress+levine $\&$ ots $=\mathrm{FH} 3 \mathrm{Q}$ yoUb 
2s\&sig=vBR19eR4vOACNeL8H8-

HjZtMrQ8\#v=onepage\&q=social\%20stress\%20levine\&f=false $>$. Acesso em 06/06/2015.

LIMA, A. C. C.; STEFANO, S. R.; ZAMPIER, M. A. Satisfação da qualidade de vida no trabalho dos professores de arte da rede escolar no interior do Paraná. Revista Capital Científico - Eletrônica, v. 9, n. 1, p. 99-112, jan./jun., 2011. Disponível em: < http://www.spell.org.br/documentos/ver/33036/satisfacao-da-qualidade-de-vida-no-trabalhodos-professores-de-arte-da-rede-escolar-no-interior-do-parana >. Acesso em 27/07/2015.

LIMA, F. B. Stress, qualidade de vida, prazer e sofrimento no trabalho de call center. Campinas: 2004, 114 p. Dissertação (Mestrado em Psicologia) - Programa de Pós-Graduação Psicologia, Centro de Ciências da Vida, Pontifícia Universidade Católica de Campinas PUC-Campinas. Disponível em: $\quad$ http://www.bibliotecadigital.puccampinas.edu.br/tde arquivos/6/TDE-2007-05-17T051105Z1322/Publico/dissertacaocompleta.pdf>. Acesso em: 09/04/15.

LIMA, I. B. A. Amplitude conceitual da segurança no cumprimento de ordem judicial pelo oficial de justiça face à Dignidade da Pessoa Humana. Jus Navigandi. 2014. Disponível em: $<$ http://jus.com.br/artigos/33995/amplitude-conceitual-da-seguranca-no-cumprimento-deordem-judicial-pelo-oficial-de-justica-face-a-dignidade-da-pessoa-humana>. Acesso em: 21/04/2015.

LIMONGI-FRANÇA, A. C. Indicadores empresariais de qualidade de vida no trabalho: esforço empresarial e satisfação dos empregados no ambiente de manufaturas com certificação ISSO 9000. São Paulo: 1996, 355 p. Tese (Doutorado em Administração) Departamento de Administração, Faculdade de Economia, Administração e Contabilidade, Universidade de São Paulo. Disponível em: < http://www.teses.usp.br/teses/disponiveis/12/12132/tde-14042009-113324/pt-br.php>. Acesso em: 19/07/15.

LIMONGI-FRANÇA, A. C.; RODRIGUES, A. L. Stress e trabalho: uma abordagem psicossomática. $4^{\mathrm{a}}$ ed., $2^{\mathrm{a}}$ reimp., 217p. São Paulo: Atlas, 2007, 191 p.

LIMONGI-FRANÇA, A. C. Psicologia do trabalho: psicossomática, valores e práticas organizacionais. 299 p. São Paulo: Saraiva, 2008.

LIMONGI-FRANÇA, A. C. Qualidade de vida no trabalho - QVT: conceitos e práticas nas empresas da sociedade pós-industrial. $2^{\mathrm{a}}$ ed., $4^{\mathrm{a}}$ reimp., São Paulo: Atlas, 2009.

LIMONGI-FRANÇA, A. C. Práticas de recursos humanos - PRH: conceitos, ferramentas e procedimentos. 267p. $1^{\text {a }}$ ed. $4^{\text {a }}$ reimpr. São Paulo: Atlas, 2010. 
LIPP, M. E. N.; MALAGRIS, L. E. N.; NOVAIS, L. E. Stress ao longo da vida. p.111, São Paulo: Ícone, 2007.

MARTINIANO, A. S. Aplicação de técnica da mineração de dados na identificação do perfil de empregados absenteístas e presenteístas em uma empresa de courier da cidade de São Paulo. São Paulo: 2012. 130 p. Dissertação (Mestrado em Engenharia de Produção) Programa de Pós-Graduação em Engenharia de Produção, Universidade Nove de Julho UNINOVE. Disponível em: $<$ http://www.uninove.br/PDFs/Mestrados/Eng/Resumos_dissertacoes_2012/Disseratacao_An drea_Martiniano.pdf >. Acesso em: 25/04/2015.

MATSUURA, L. Justiça na rua: morte de Oficial de Justiça expõe desafios da profissão. Revista Consultor Jurídico. 2009. Disponível em <http://www.conjur.com.br/2009-mai10/entrevista-yvone-barreiros-moreira-oficial-justica-sao-paulo>. Acesso em: 13/04/2015.

Medibank Private. The cost of workplace stress in Australia. 2008. Disponível em: $\langle$ http://www.medibank.com.au/client/documents/pdfs/the-cost-of-workplace-stress.pdf $>$.

Acesso em: 19/04/2015.

MERLO, A. R. C.; DORNELLES, R. A. N.; BOTTEGA, C. G.; TRENTINI, L. O trabalho e a saúde dos Oficiais de Justiça Federal de Porto Alegre. Cadernos de Psicologia Social do Trabalho. v. 15, n. 1, p. 101-113, 2012. Disponível em: <http://www.revistas.usp.br/cpst/article/view/49624/53727>. Acesso em: 13/04/2015.

MICHIE, S. Causes and management of stress at work. Occupational e Environmental Medicine, 2002, v. 59, n. 01, p. 67-72. Disponível em: <http://oem.bmj.com/content/59/1/67.full.pdf+html >. Acesso em: 23/04/2015.

MIYAMOTO, S. T.; SALMASO, C.; MEHANNA, A.;BATISTELA, A. E.; SATO, T.; GREGO, M. L. Fisioterapia preventiva atuando na ergonomia e no stress no trabalho. Fisioterapia e Pesquisa - Revista de Fisioterapia da Universidade de São Paulo. v. 6, n. 1, p. 83-91, jan./jun., $1999 . \quad$ Disponível em: <http://www.revistas.usp.br/fpusp/article/view/79596>. Acesso em 07/06/2015.

MOSADEGHRAD, A. M. Occupational Stress and Turnover Intention: Implications for Nursing Management. International Journal of Health Policy and management. Article 17, v. 01, n. 02, p. 169-176, 2013. Disponível em: < http://www.ijhpm.com/article_2749_584.html $>$. Acesso em: 21/04/2015.

NAKAYAMA, M. K. A influência da cultura organizacional na predisposição do gerente ao estresse ocupacional. Porto Alegre: 1997. 168 p. Tese (Doutorado em Administração) 
Escola de Administração, Departamento de Administração, Programa de Pós-Graduação em Administração, Universidade Federal do Rio Grande do Sul. Disponível em: <http://tupi.fisica.ufmg.br/michel/docs/Artigos_e_textos/Cultura_e_cultura_organizacional/00 7\%20-\%20A\%20influ\%EAncia\%20da\%20cultura\%20organizacional\%20-\%20Tese.pdf >. Acesso em: 06/06/2015.

OLIVEIRA, P. M.; LIMONGI-FRANÇA, A. C. Avaliação da gestão de programas de qualidade de vida no trabalho. Revista de Administração de Empresas - RAE-eletrônica. v. 4, n. 1, artigo 9, jan./jun., 2005. Disponível em: <http://www.scielo.br/pdf/raeel/v4n1/v4n1a05>. Acesso em 06/06/2015.

PAFARO, R. C.; DE MARTINO, M. M. F. Estudo do estresse do enfermeiro com dupla jornada de trabalho em um hospital de oncologia pediátrica de Campinas. Revista da Escola de Enfermagem da USP, São Paulo, v. 38, n. 2, 2004, p. 152-160. Disponível em: <http://www.revistas.usp.br/reeusp/article/viewFile/41391/44970>. Acesso em: 25/04/2014.

PASCHOAL, T.; TAMAYO, A. Validação da escala de estresse no trabalho. Estudos de Psicologia. v. 9 , n. 1, p. 45-52, 2004. Disponível em: <http://www.scielo.br/pdf/epsic/v9n1/22380.pdf>. Acesso em: 23/05/2015.

PARKER, D. F.; DE COTIIS, T. A. Organizational determinants of job stress. Organizational Behavior and Human Performance. v. 32, p. 160-177, 1983. Disponível em: $<$ http://deepblue.lib.umich.edu/bitstream/handle/2027.42/25099/0000531.pdf\&embedded=tru e? sequence=1>. Acesso em: 09/04/2015.

PAZINI, M. H.; STEFANO, S. R. A qualidade de vida no trabalho e satisfação: um estudo multi-casos com os funcionários das empresas do sistema "S". II Encontro de Gestão de Pessoas e Relações de Trabalho - EnGPR 2009, Curitiba: 2009. Disponível em: <http://www.anpad.org.br/diversos/trabalhos/EnGPR/engpr_2009/2009_ENGPR150.pdf〉. Acesso em 19/07/2015.

PIMENTEL, D. Diligência judicial sob risco. O Liberal. 2014. Disponível em: <http://www.tjpa.jus.br/PortalExterno/imprensa/noticias/Informes/988-Diligencia-judicialsob-risco.xhtml>. Acesso em: 07/04/2015.

RAUPP, F. M.; BEUREN, I. M.. Metodologia da pesquisa aplicável às ciências sociais. In. BEUREN, Ilse Maria. (Org). Como elaborar trabalhos monográficos em contabilidade. 3.ed. São Paulo: Atlas, 2006.

REZENDE, F. S. S.O.S. Polícia! - Estresse no trabalho: estudo no centro integrado de 
comunicações operacionais (atendimento de urgência 190) da Polícia Militar de Minas Gerais na região metropolitana de Belo Horizonte. Belo Horizonte: 2010, 123 p. Dissertação (Mestrado em Administração) - Centro de Pós-Graduação e Pesquisa em Administração, Faculdade de Ciências Econômicas, Universidade Federal de Minas Gerais UFMG. Disponível em: http://www.bibliotecadigital.ufmg.br/dspace/bitstream/handle/1843/BUBD9A4FGD/disserta_o_fabiana_santos_rezende.pdf?sequence=1 >. Acesso em: 16/08/15.

ROBBINS, S. Comportamento organizacional. tradução técnica: Reynaldo Marcondes, $11^{\mathrm{a}}$ ed., 536 p. São Paulo: Pearson Prentice Hall, 2005.

SADIR, M. A.; LIPP, M. E. N. As fontes de stress no trabalho. Revista de Psicologia da IMED. v. 01, n. 01, p. 114-126, 2009. Disponível em: $<$ http://seer.imed.edu.br/index.php/revistapsico/article/viewFile/16/16 $>$. Acesso em: $13 / 04 / 2015$.

SADIR, M. A.; BIGNOTTO, M. M.; LIPP, M. E. N. Stress e qualidade de vida: influência de algumas variáveis pessoais. Paidéia. v. 20, n. 45, p. 73-81, jan./abr., 2010. Disponível em <http://www.scielo.br/pdf/paideia/v20n45/a10v20n45.pdf $>$. Acesso em: 12/04/2015.

SAMPAIO, R, F. V. Percepção de estressores ocupacionais e sua relação com fatores geradores de qualidade de vida no trabalho de agentes de trânsito: um estudo de caso. São João Del-Rey: 2010. 141 p. Dissertação (Mestrado em Psicologia) - Programa de PósGraduação em Psicologia, Universidade Federal de São João Del-Rey. Disponível em: $<$ http://www.ufsj.edu.br/portal2-

repositorio/File/mestradopsicologia/2010/Dissertacoes/DISSERTACAORENATA.pdf>.

Acesso em: 15/04/2015.

SANTOS, C. L. M. Proposta de um sistema de gestão de estresse para médicos em hospitais baseado na OHSAS 18001. João Pessoa: 2008, 113 p. Tese (Doutorado em Engenharia de Produção) - Programa de Pós-Graduação em Engenharia de Produção, Centro de Tecnologia, Universidade Federal da Paraíba. Disponível em: <http://tede.biblioteca.ufpb.br/bitstream/tede/5276/1/arquivototal.pdf $>$. Acesso em: 06/06/15.

SILVA, R. R. Uma análise da pressão no trabalho, da liberdade e do apoio social entre servidores de um tribunal. Cadernos de Psicologia Social do Trabalho. v. 12, n. 1, p. 123135, 2009. Disponível em: <http://www.revistas.usp.br/cpst/article/viewFile/25768/27501>. Acesso em 04/06/2015.

SINTRAJUFE RS, Sindicato dos Trabalhadores do Judiciário Federal no Rio Grande do Sul. Pesquisa de saúde dos Oficiais de Justiça. 2013. Disponível em: $<$ http://assojafgo.org.br/wp-content/uploads/2013/09/Pesquisa-sobre-a-saude-dos-oficiais-de- 
justica.pdf>. Acesso em: 07/04/2015.

SONNENTAG, S.; FRESE, M. Stress in organizations. In: Handbook of Psychology, volume 12: Industrial and Organizational Psychology, eds. Walter C. Borman, Daniel R. Ilgen and Richard J. Klimoski. Chapter 18, p. 453-491. New York: Wiley, 2003.

STEFANO, S. R.; BONANATO, F. M.; RAIFUR, L. Estresse em funcionários de uma instituição de ensino superior: diferenças entre gênero. Revista Economia e Gestão - E\&G. v. $13, \quad$ n. $31, \quad$ p. 73-92, jan./abr., 2013. Disponível em: <http://www.spell.org.br/documentos/ver/10292/estresse-em-funcionarios-de-uma-instituicaode-ensino-superior--diferencas-entre-genero>. Acesso em: 07/04/2015.

SWA, Safe Work Austrália. The incidence of accepted workers' compensation claims for mental stress in Australia. 2013.2 Disponível em: $<$ http://www.safeworkaustralia.gov.au/sites/SWA/about/Publications/Documents/769/TheIncidence-Accepted-WC-Claims-Mental-Stress-Australia.pdf $>$. Acesso em: 19/04/2015.

TAMAYO, A. Impacto dos valores da organização sobre o estresse ocupacional. Revista de Administração Contemporânea RAC-Eletrônica, v.1, n. 2, art. 2, p. 20-33, mai./ago., 2007. Disponível em: <http://www.spell.org.br/documentos/ver/30978/impacto-dos-valores-daorganizacao-sobre-o-estresse-ocupacional>. Acesso em: 12/04/2015.

TAVARES, F. A. Estresse em motoristas de transporte coletivo urbano por ônibus. Uberlândia 2010, 88 p. Dissertação (Mestrado em Psicologia Aplicada) - Programa de PósGraduação em Psicologia, Instituto de Psicologia, Universidade Federal de Uberlândia. Disponível em: <http://www.bdtd.ufu.br//tde busca/arquivo.php?codArquivo=3107>. Acesso em 30/05/2015.

Tribuna Judiciária. Ano 25, n. 39, abr./mai./jun. 2009, p. 12-15. Disponível em: $<$ http://www.aojesp.org.br/tribuna/Tribuna_39.pdf $>$. Acesso em: 13/04/2015.

TRT 18 - Tribunal Regional do Trabalho da $18^{\text {a }}$ Região. $1^{\text {a }}$ Pesquisa online sobre qualidade de vida no trabalho no TRT da $\mathbf{1 8}^{\mathbf{a}}$ Região - 2011. Disponível em: <http://www.trt18.jus.br/intranet/arquivos/2012/06/relatorio_da_pesquisa_de_qvt_2011.pdf>. Acesso em: 07/04/2015.

TST - Tribunal Superior do Trabalho. Notícias do TST. Presidente do TST pede que TRTs intensifiquem medidas de segurança para Oficiais de Justiça. 2014. Disponível em: <http://www.tst.jus.br/noticias/-/asset_publisher/89Dk/content/presidente-do-tst-pede-quetrts-intensifiquem-medidas-de-seguranca-para-oficiais-de-justica>. Acesso em: 13/04/2015. 
VASCONCELOS, A. F. Qualidade de vida no trabalho: origem, evolução e perspectivas. Caderno de Pesquisas em Administração. São Paulo, v. 08, n. 1, jan./mar., p. 23-35, 2001. Disponível em: <http://www.ead.fea.usp.br/cad-pesq/arquivos/v08-1art03.pdf>. Acesso em: 06/06/2015.

VISENTINI, M. S.; REIS, E. D.; SIQUEIRA, N. A.; VIEIRA, K. M.; RODRIGUES, C. M. C. Empresa doente, funcionário estressado: analisando a saúde organizacional como influenciadora do stress no trabalho. Revista de Ciências da Administração, v. 12, n. 26, p. 189-220, 2010. Disponível em: <http://www.spell.org.br/documentos/ver/4779/empresadoente--funcionario-estressado--analisando-a-saude-organizacional-como-influenciadora-dostress-no-trabalho>. Acesso em: 27/04/2015.

WOTTRICH, S. H.; ÁVILA, C. M.; MACHADO, C. C.; GOLDMEIER, S.; DILLENBURG, D.; KUHL, C. P.; IRIGOYEN, M. C.; RIGATTO, K.; RUSCHEL, P. P. Gênero e manifestação de stress em hipertensos. Estudos de Psicologia. Campinas: v. 28, n. 1, jan./mar., p. 27-34, 2011. Disponível em: <http://www.scielo.br/pdf/estpsi/v28n1/a03v28n1.pdf>. Acesso em: $10 / 06 / 2015$.

ZANELATO, L. S. Manejo de stress, coping e resiliência em motoristas de ônibus urbano. Bauru: 2008. 141 p. Dissertação (Mestrado em Psicologia do Desenvolvimento e Aprendizagem) - Programa de Pós-Graduação em Psicologia, Faculdade de Ciências, Campus Universitário de Bauru, Universidade Estadual Paulista. Disponível $\mathrm{em}:<$ http://base.repositorio.unesp.br/bitstream/handle/11449/97479/zanelato_ls_me bauru.pd

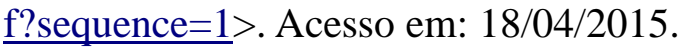

ZILLE, L.; BRAGA, C. D.; MARQUES, A. L. Estresse no trabalho: um desafio para os gestores das organizações brasileiras. Revista de Gestão - REGE. São Paulo - SP: v. 21, n. 3, p. 401-413, jul./set., 2014. Disponível em: $<$ http://www.spell.org.br/documentos/ver/33898/estresse-no-trabalho--um-desafio-para-osgestores-das-organizacoes-brasileiras >. Acesso em: 07/05/2015.

ZILLE, L. P. Novas perspectivas para a abordagem do estresse ocupacional em gerentes: estudo em organizações brasileiras de diversos setores. Belo Horizonte: 2005, 253 p. Tese (Doutorado em Administração) - Centro de Pós-Graduação e Pesquisa em Administração, Faculdade de Ciências Econômicas, Universidade Federal de Minas Gerais - UFMG. Disponível em: < http://www.dominiopublico.gov.br/download/texto/cp019191.pdf>. Acesso em: 16/08/15.

Lei No 11.416 <http://www.planalto.gov.br/ccivil_03/_ato2004-2006/2006/lei/111416.htm>. Acesso em 13/04/2016.

Lei $\mathrm{N}^{\circ}$ 13.105, de 16 de março de 2015 <http://www.planalto.gov.br/ccivil_03/_ato20152018/2015/lei/113105.htm>. Acesso em $21 / 06 / 2016$ 
APÊNDICES A - Instrumento de Pesquisa 
O (a) senhor (a) está sendo convidado (a) a participar deste estudo, que consiste em responder a um questionário relacionado a sua rotina de trabalho. Este questionário tem por objetivo obter dados para estudar o estresse ocupacional no trabalho dos Oficiais de Justiça Avaliadores Federais. O questionário é composto de perguntas predominantemente fechadas sobre a estrutura e os processos de trabalho desempenhados pelos Oficiais de Justiça Avaliadores Federais. Este questionário possui em torno de 55 perguntas e o tempo estimado para a sua realização é, em média, 15 minutos. A aplicação do questionário é feita pelo Google drive e você não deverá se identificar, uma vez que o estudo levará em conta informações globais sobre a amostra pesquisada. As informações prestadas são sigilosas e serão tratadas em conjunto com as de outros respondentes. A divulgação dos resultados da pesquisa conterá apenas resultados agregados, o que não permitirá a identificação do respondente. A sua participação é voluntária. O (a) senhor (a) não será penalizado (a) caso se recuse a participar. Os participantes não receberão qualquer tipo de benefício material pela sua participação. O benefício direto desta pesquisa é a sistematização e a disponibilização, para a Universidade e a organização, de dados e informações relevantes sobre o tema pesquisado. A sua colaboração é muito importante para que se possa entender melhor o estresse no trabalho, contribuindo, dessa maneira, com estudos científicos que possam servir de referencial para aplicação nas organizações. Agradecemos a sua valiosa contribuição para a realização desta pesquisa e nos colocamos a sua disposição para tirar qualquer dúvida ou para maiores esclarecimentos (pesquisasquestionario@gmail.com).

Você aceita, espontaneamente, participar deste estudo?

( ) $\operatorname{Sim} \quad$ ( ) Não

1- Gênero:

( ) Feminino ( ) Masculino

2- Idade:

( ) Até 30 anos ( ) De 31 a 40 anos ( ) De 41 a 50 anos ( ) Acima de 50 anos

3- Estado civil:

( ) Casado(a)/União estável ( ) Solteiro(a) ( ) Viúvo(a) ( ) Divorciado(a) ( )Outros 
4- Há quanto tempo exerce o cargo de Oficial de Justiça Avaliador Federal:

( ) Até 5 anos ( ) De 6 a 10 anos ( ) De 11 a 20 anos ( ) Acima de 21 anos

5- Marque seu nível de instrução mais elevado (completo):

( ) Ensino médio completo ( ) Superior completo ( ) Pós-Graduação completa

( ) Mestrado completo ( ) Doutorado completo

6- Você exerce atividade profissional além da desenvolvida no Judiciário?

( ) $\operatorname{Sim}$ ( ) Não

7- Qual a sua lotação:

( ) Capital ( ) Região Metropolitana ( ) Interior

8- Você já sofreu algum tipo de Ameaça/violência/ agressão verbal ou física no desempenho da atividade profissional?

( ) Sim, verbal ( ) Sim, física ( ) Sim, verbal e física ( ) Não

9- Já teve algum bem particular danificado ou roubado no exercício da função?

( ) Sim, danificado ( ) Sim, roubado ( ) Sim, danificado e roubado ( ) Não

10- No caso de dano ou furto, teve seus prejuízos ressarcidos pela administração?

( ) $\operatorname{Sim}$ ( ) Não

11- Sente-se seguro durante o exercício da função?

( ) $\operatorname{Sim}$ ( ) Não

12- Caso tenha respondido não à pergunta anterior, quais os fatores que mais contribuem para a insegurança?

13- Você recebeu treinamento para realizar as tarefas?

( ) Sim ( ) Não 
14- Se respondeu "sim", indique de quem recebeu treinamento:

15- Você usa telefone celular particular para o desempenho de suas tarefas?

( ) $\operatorname{Sim}$ ( ) Não

16- Qual o tipo de mandado você considera mais desgastante?

17- Dentre as atividades que cumpre, qual(is) a(s) que lhe é(são) mais penosa(s)? Explique:

Considerando suas atitudes frente ao meio ambiente, gostaríamos que você manifestasse sua opinião em relação às afirmações a seguir. Para as suas respostas, considere o que vem acontecendo com você nos últimos seis meses. Para tal, utilize a escala de concordância de cinco posições, em que "1" representa "Discordo Totalmente" e "5" representa "Concordo Totalmente", assinalando o número escolhido.

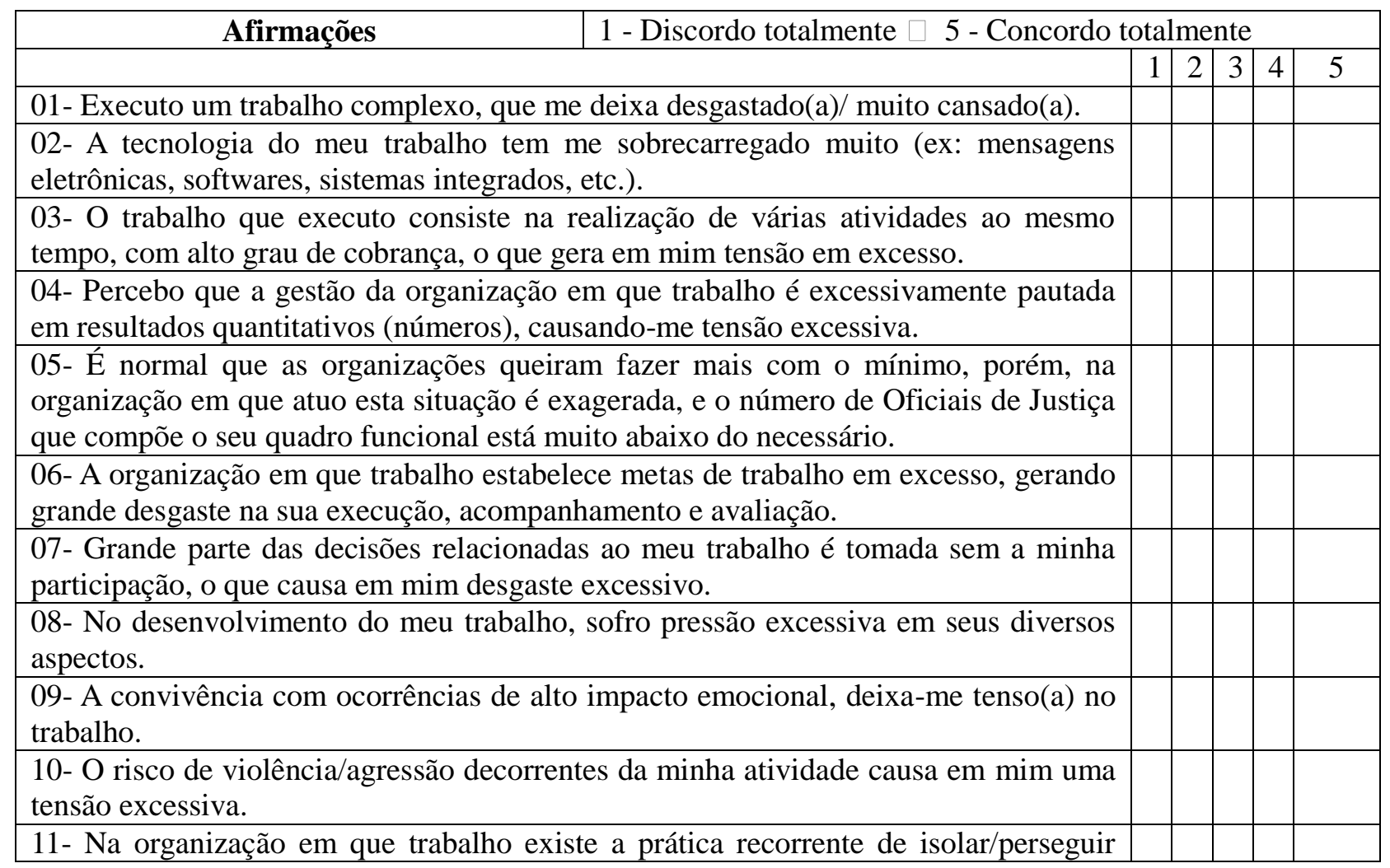


pessoas que eventualmente sejam consideradas funcionalmente inadequadas (assédio moral).

12- Há situações de desrespeito humano na organização em que trabalho.

13- Para atingir os resultados que a organização exige, muitas vezes, defronto-me com situações em que há orientações superiores, explícitas ou implícitas, para agir fora do que considero eticamente correto.

14- Muitos prazos e prazos apertados são rotina no meu trabalho, acarretando-me grande incômodo e tensão excessiva.

15- As minhas atividades na organização em que trabalho geram uma excessiva carga de trabalho, o que, de certa forma, está ultrapassando os meus limites e gerando significativa fonte de tensão em mim.

16- Conheço o que é qualidade de vida no trabalho, bem como sua importância, mas não tenho tempo de praticar esses conceitos devido à absorção pelo trabalho.

17- Tenho dificuldade de compatibilizar os compromissos de trabalho com os compromissos de família, sociais, entre outros.

18- Vivencio conflitos por estar em sobrecarga, mas não ter como questioná-la.

19- Convivo com situações de tensão excessiva inerente às relações humanas no trabalho.

20- Na organização em que trabalho, há um canal aberto de comunicação para discussão das situações de dificuldade e tensão vivenciadas.

21- Percebo que na organização em que atuo há uma colaboração dos colegas de trabalho na execução das tarefas desempenhadas.

22- O trânsito me deixa tensionado excessivamente.

23- Os endereços incompletos ou insuficientes, constantes nos mandados, me causam tensão excessiva.

Você considera existir no seu ambiente de trabalho outros fatores causadores de tensão excessiva que não tenham sido considerados nas questões anteriores? Caso existam, descrevaos, de forma objetiva, e aponte o grau, conforme as perguntas anteriores.

Fonte: Adaptado de Zille (2005); Rezende (2010) e Merlo et al. (2012).

\begin{tabular}{|c|c|c|c|c|c|}
\hline 1 - Discordo totalmente $\square 5$ - Concordo tota & men & & & & \\
\hline & $1 \mid$ & 2 & 3 & 4 & 5 \\
\hline 1- Sinto que a quantidade de trabalho a ser executado aumentou nos últimos 05 anos. & & & & & \\
\hline 2- Sinto que a dificuldade de realizar o meu trabalho aumentou nos últimos 05 anos. & & & & & \\
\hline 3- Percebo que há competitividade entre os meus colegas de trabalho. & & & & & \\
\hline $\begin{array}{l}\text { 4- A maioria dos Diretores de Vara procura a minha colaboração quando existem } \\
\text { decisões que influem no cumprimento do mandado }\end{array}$ & & & & & \\
\hline $\begin{array}{l}\text { 5- A maioria dos Diretores de Vara explica o motivo das ordens e das decisões } \\
\text { importantes }\end{array}$ & & & & & \\
\hline 6- Eu me sinto respeitado pela maioria dos Diretores de Varas. & & & & & \\
\hline $\begin{array}{l}\text { 7- } \mathrm{O}(\mathrm{A}) \text { juiz(a) conversa comigo, previamente, sobre o teor da ordem existente no } \\
\text { mandado. }\end{array}$ & & & & & \\
\hline $\begin{array}{l}\text { 8- Os bons resultados alcançados por mim em meu trabalho são reconhecidos pela } \\
\text { organização em que trabalho. }\end{array}$ & & & & & \\
\hline
\end{tabular}




\begin{tabular}{|l|l|l|l|}
\hline 9- Eu me sinto seguro(a) tecnicamente para realizar minhas tarefas no trabalho. & & & \\
\hline $\begin{array}{l}\text { 10- O(A) meu(minha) superior procura a minha colaboração quando há decisões que } \\
\text { me afetam. }\end{array}$ & & & \\
\hline $\begin{array}{l}\text { 11- Eu costumo conversar com os(as) colegas Oficiais sobre problemas relacionados } \\
\text { ao trabalho. }\end{array}$ & & & \\
\hline $\begin{array}{l}\text { 12- Percebo que as ordens contidas nos mandados são expressas de forma clara, não } \\
\text { gerando dúvidas na sua execução. }\end{array}$ & & & \\
\hline $\begin{array}{l}\text { 13- Os mandados que recebo contém todas as informações necessárias, evitando, } \\
\text { desse modo, que eu tenha que buscar complementações junto às Varas. }\end{array}$ & & & \\
\hline $\begin{array}{l}\text { 14- No meu trabalho, o (a) Juiz (a) possibilita um contato posterior caso haja } \\
\text { necessidade de algum tipo de esclarecimento acerca do teor da ordem existente no } \\
\text { mandado. }\end{array}$ & & & \\
\hline
\end{tabular}

Fonte: Merlo et al. (2012). 
APÊNDICE B - Termo de consentimento de pesquisa 


\section{Universidade Estadual do Centro-Oeste}

\section{Mestrado Profissional em Administração}

\section{Termo de Consentimento Livre e Esclarecido}

A mestranda Patrícia Inez da Silva Machado, do Mestrado Profissional em Administração da Universidade Estadual do Centro-Oeste está desenvolvendo um estudo acerca dos fatores estressores ocupacionais com os Oficiais de Justiça Avaliadores Federais do Tribunal Regional do Trabalho da $18^{\text {a }}$ Região.

O (a) senhor (a) está sendo convidado (a) a participar deste estudo, que consiste em responder a um questionário relacionado à sua rotina de trabalho. Este questionário tem por objetivo obter dados para estudar o estresse ocupacional no trabalho dos Oficiais de Justiça Avaliadores Federais. O questionário é composto de perguntas predominantemente fechadas sobre a estrutura e os processos de trabalho desempenhados pelos Oficiais de Justiça Avaliadores Federais. Este questionário possui em torno de 54 perguntas e o tempo estimado para a sua realização é, em média, de 30 minutos. A aplicação do questionário é feita coletivamente e você não deverá se identificar, uma vez que o estudo levará em conta informações globais sobre a amostra pesquisada. As informações prestadas são sigilosas e serão tratadas em conjunto com as de outros respondentes. A divulgação dos resultados da pesquisa conterá apenas resultados agregados, o que não permitirá a identificação do respondente. A sua participação é voluntária. $\mathrm{O}$ (a) senhor (a) não será penalizado (a) caso se recuse a participar. Os participantes não receberão qualquer tipo de benefício material pela sua participação. O benefício direto desta pesquisa é a sistematização e a disponibilização para a Universidade e a organização de dados e informações relevantes sobre o tema pesquisado.

A sua colaboração é muito importante para que se possa entender melhor o estresse no trabalho, contribuindo, dessa maneira, com estudos científicos que possam servir de referencial para aplicação nas organizações.

Agradecemos a sua valiosa contribuição para a realização desta pesquisa e nos colocamos a sua disposição para tirar qualquer dúvida ou para maiores esclarecimentos (pesquisasquestionário@gmail.com).

Você aceita, espontaneamente, participar deste estudo:

( ) $\operatorname{Sim}$ ( ) Não

Fonte: Adaptado de Zille (2005); Rezende (2010). 